\title{
OCEANA
}

\section{PROTECTING \\ THE NORTH SEA: BROWN BANK}

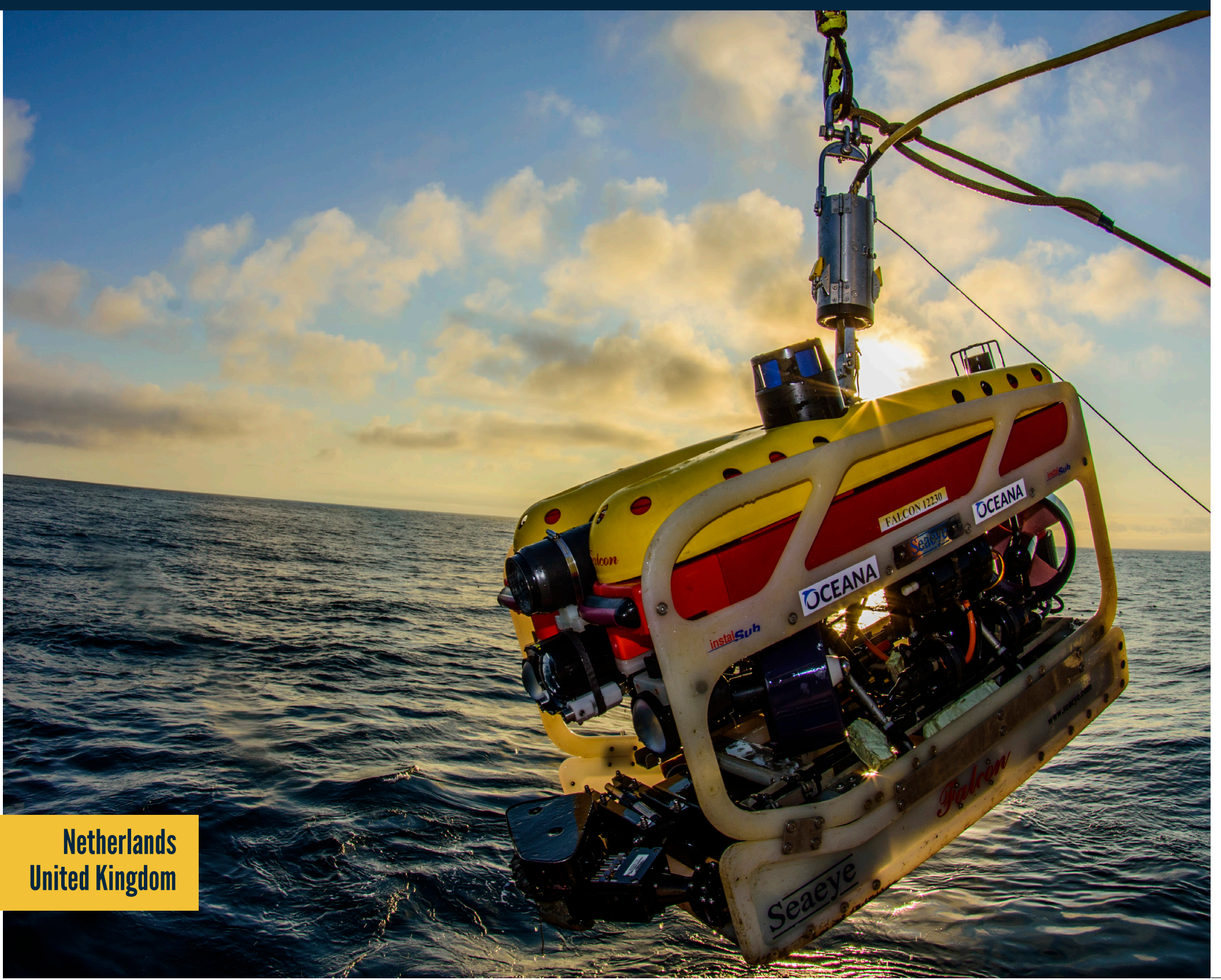




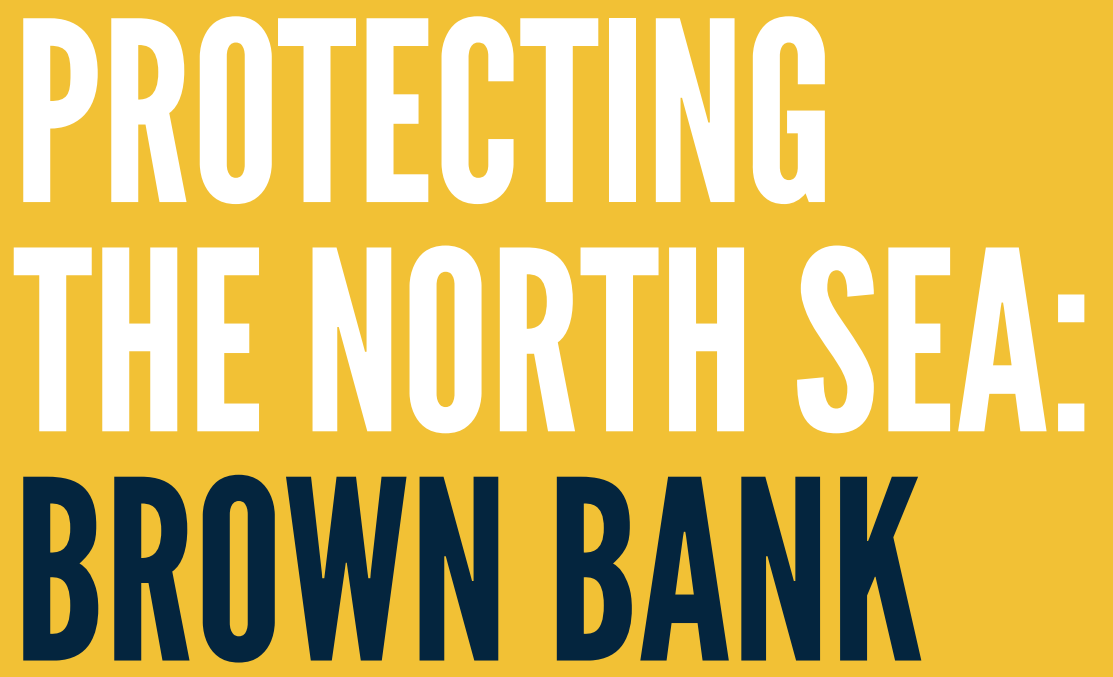

CREDITS

Citation: García, S., Álvarez, H., Perry, A.L., Blanco, J., Maaholm, D.J., Aguilar, R. 2019. Protecting the North Sea: Brown Bank. Oceana, Madrid. 64 p.

Cover: Remotely operated vehicle @ O OCEANA/ Juan Cuetos

All photos are $\subseteq$ OCEANA, unless otherwise stated.

Acknowledgments:

Oceana gratefully acknowledges the collaboration of the North Sea Foundation, particularly Jip Vrooman, who generously shared her knowledge of Dutch marine policy and provided helpful comments on earlier versions of this report. We also thank the DISCLOSE project, particularly Leo Koop (Delft University of Technology), Sarah O'Flynn (Royal Netherlands Institute for Sea Research), and Karin van der Reijden (University of Groningen), who joined the Dutch leg of the 2017 expedition and contributed to its success. Oceana warmly acknowledges the crew of MV Neptune for their hard work and assistance during both the 2016 and 2017 expeditions.

This project was made possible thanks to the generous support of the Dutch Postcode Lottery. 


\section{EXECUTIVE SUMMARY, 4}

INTRODUCTION, 5

DESCRIPTION OF THE AREA, 6

Bathymetry and substrate, 7

Known ecological features of interest, 8

Previous research surveys in the area, 10

Threats, 12

Fishing, 13

Wind energy development, 15

Oil and gas exploitation, 16

Shipping, 17

Current management measures, 18

Previous conservation proposals, 19

Oceana suRVEys, 21

Methods, 22

ROV surveys, 22

Infaunal sampling, 23

DISCLOSE project, 23

Results, 25

Community types, 25

Detritic sandy bottom with shell remains with occasional pebbles, 26

Sabellaria spinulosa aggregations and reefs on soft bottom, 27

Artificial substrata (wrecks) covered by invertebrates, 29

Features of conservation interest, 30

Threatened and protected habitats, 31

Threatened and protected species, 33

Commercial species, 37

Anthropogenic impacts, 39

PROPOSAL FOR PROTECTION, 40

RefERENCES, 45

AnNeX: ReCORDED tAXA, 60 
ocated at the centre of the southern North Sea, Brown Bank _(also known as Brown Ridge, and as Bruine Bank in Dutch) is a ridge formed by a series of large-scale sandbanks in Dutch and UK waters. It is a recognised area of ecological interest, due mainly to the high abundance of cetaceans and seabirds in the area. To date, however, Brown Bank has been granted very limited protection. The UK side is protected for a single species (harbour porpoise), within the Southern North Sea MPA. No protection is in place for the Dutch side, although it qualifies for inclusion in the Natura 2000 network due to the high numbers of seabirds that it supports, particularly common guillemot and razorbill.

Despite the known importance of Brown Bank for marine life, relatively less attention has been paid to its benthic biodiversity. To address this information gap, Oceana carried out two research surveys in 2016 and 2017, to gather information about benthic species and communities. Surveys were carried out via a remotely operated vehicle and infaunal grab sampling, aided by a multibeam echosounder and side-scan sonar.

In total, 204 taxa were identified. These taxa included nine priority species for conservation, and a range of commercially fished species, including fishes for which Brown Bank provides spawning or nursery habitat. The most noteworthy discovery was the presence of biogenic reefs formed by ross worm (Sabellaria spinulosa), a sedimentary polychaete. These reefs covered a total area of $1023 \mathrm{~m}^{2}$ on the Dutch side of Brown Bank, and hosted a variety of associated species, including various crabs, common dragonet, and lesser spotted dogfish. Such biogenic reefs have nearly disappeared from Dutch waters, and ross worm reefs were previously thought to have been long-extinct in the area.

On the basis of this important discovery, Oceana recommends that Dutch waters of Brown Bank be protected immediately, in order to safeguard the fragile reefs. Such measures to protect and recover the reefs are required under both EU and international conservation frameworks. Critically, anthropogenic threats to the seabed must be minimised - particularly bottom fishing, which is intensive in the area. In parallel with protecting the newly discovered reefs, Oceana urges the Netherlands and UK governments to carry out comprehensive benthic habitat mapping of Brown Bank, to identify any additional ross worm reefs and to assess their condition and extent. 
the southern North Sea, between the Netherlands and the ПUnited Kingdom, a north-easterly flowing current sweeps water masses from the English Channel into the central North Sea. ${ }^{1}$ In this area lies Brown Bank (also known as Brown Ridge, and as Bruine Bank in Dutch). This transboundary area is characterised by sandy bottoms with a

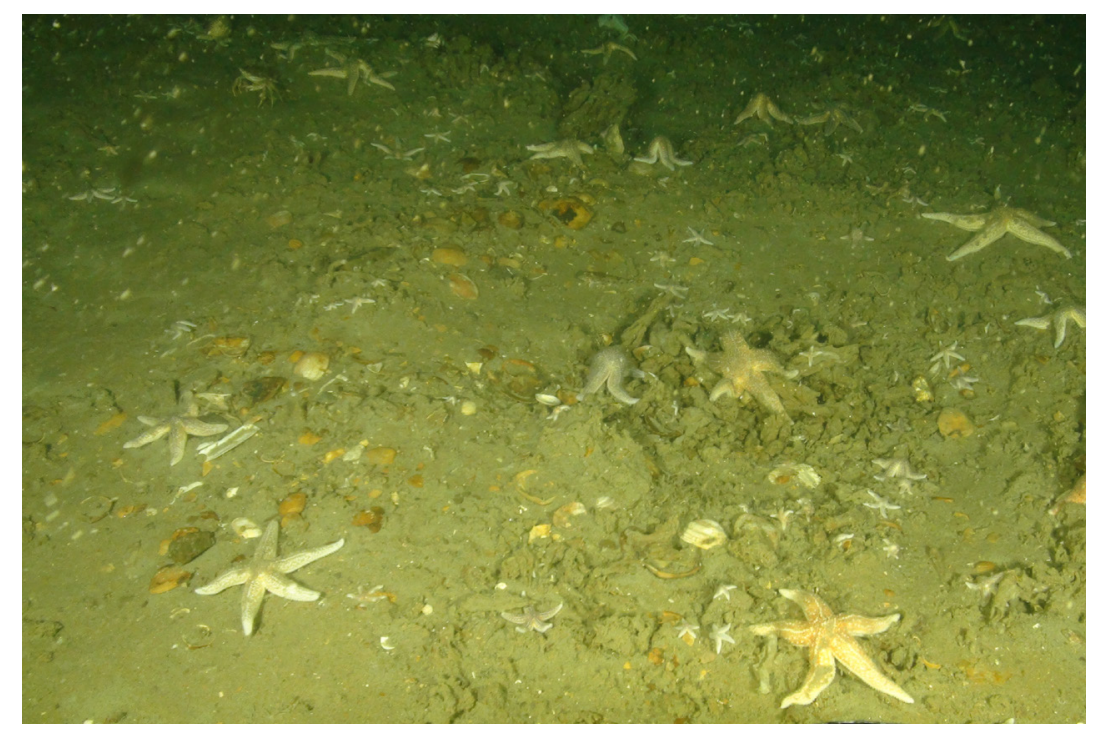
number of geologically, ecologically and archeologically interesting ridges on the seafloor, ${ }^{2,3}$ surrounded by deeper waters.

Brown Bank is a known area of key habitat for harbour porpoise (Phocoena phocoena) and on that basis was included as part of the Southern North Sea candidate Special Area of Conservation (CSAC) in the UK, under the framework of the European Habitats Directive. It is also recognised as a 'potentially ecologically valuable area' by the Dutch authorities, primarily on the basis of its importance for seabirds such as great black-backed gull (Larus marinus) and, in particular, razorbill (Alca torda) and common guillemot (Uria aalge), ${ }^{4}$ for which more than $1 \%$ of the North Sea population is regularly found in the area. ${ }^{5,6}$ However, although the Dutch part of Brown Bank qualifies for inclusion in the Natura 2000 network under the Birds Directive, its designation has been pending a decision by the government of the Netherlands for seven years.

Despite the importance of the area for both cetaceans and seabirds, relatively less research had previously been conducted on the benthic ecology of the area. Benthic ecosystems in Brown Bank are also subject to a high ongoing intensity of fishing, especially beam trawling, ${ }^{7}$ the ecological consequences of which are therefore not well known. To address the gaps in knowledge about benthic biodiversity in the area, Oceana conducted two research surveys in 2016 and 2017, to provide information about the benthic species, communities, and habitats of Brown Bank. The findings of those surveys are presented here, in the broader context of the biodiversity of the area and the threats it faces, and the implications for its protection. 


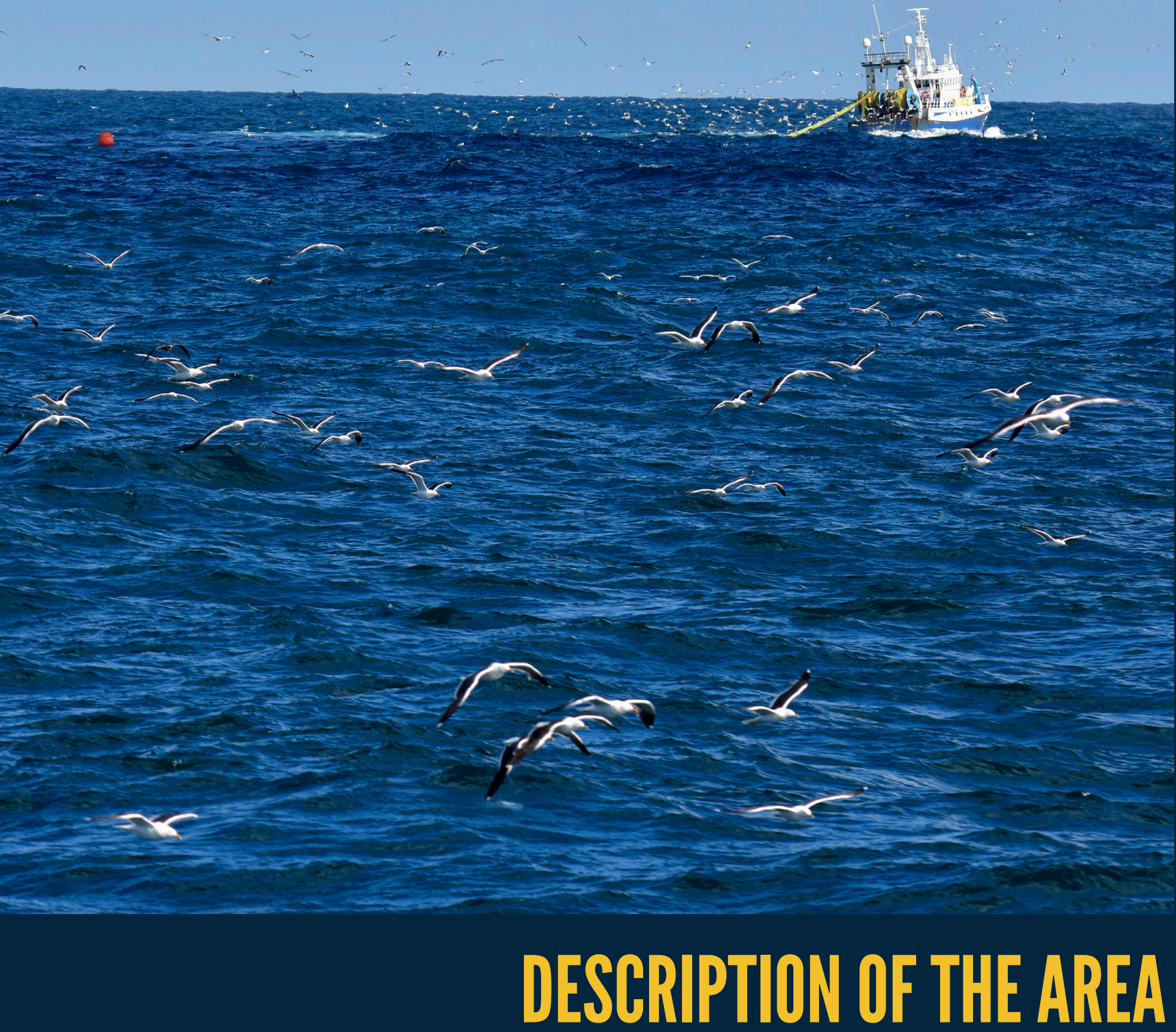


Figure 1. a) Location of Brown Bank and b) detailed bathymetry of the area.

a)

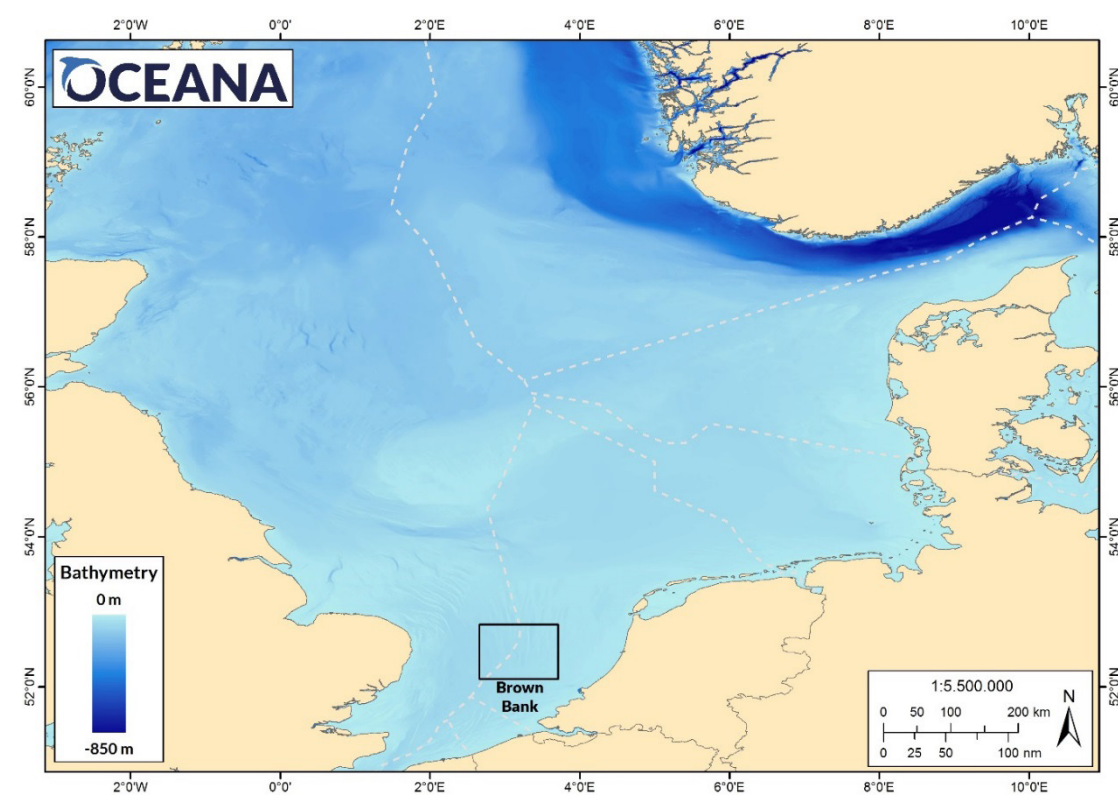

b)

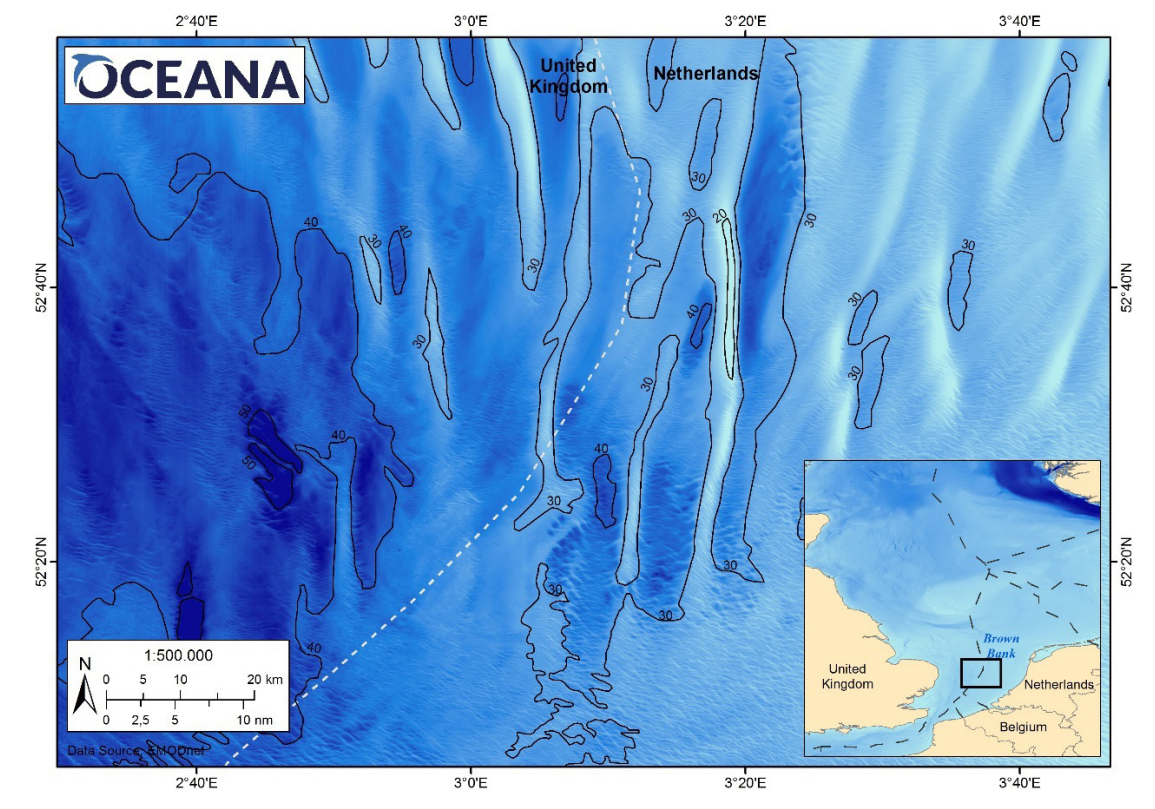

rown Bank is a ridge located in the centre of the southern North Sea (Figure 1), formed by a series of large-scale sandbanks that create an elevation in the otherwise relatively deep waters of the Southern Bight.8,9 This part of the North Sea is characterised by the presence of such sandbanks, which are topographically different from the regular seabed, due to strong hydrodynamic changes induced by water currents. ${ }^{10}$ The average depth of Brown Bank is $32 \mathrm{~m}$, with the deepest parts at around 60 $\mathrm{m}$ and the shallowest at $16 \mathrm{~m}$. The ridge rises approximately $20 \mathrm{~m}$ above the surrounding seabed and runs from north to south, with the ledges parallel to the tidal ebb and flow streams. ${ }^{8}$ This elevation results in a tidal upwelling, which concentrates zooplankton and therefore attracts associated pelagic fauna. ${ }^{11,12}$ Sand ripples have been observed to form in the area, which are nearly perpendicular (i.e., running from east to west) to the larger sandbanks. ${ }^{9}$ Little research has been done on the smaller ridges to the east, but similar depressions and ridges appear to be present. ${ }^{13,14}$

The sediment of Brown Bank consists of coarse sand with a median grain size varying between 250 and $300 \mu \mathrm{m}$ and areas of peat that emerge to the surface of the seabed. ${ }^{15}$ The percentage of organic matter in the sediment is generally low and the oxidised sediment layer is roughly $20 \mathrm{~cm}$ thick. ${ }^{2,15}$ Occasional patches of coarse and mixed sediment are known to occur in the deeper parts of the area (Figure 2).

The area is also well known for the presence of fossils, dating back to the Late Pleistocene. ${ }^{16}$ Terrestrial mammal species were 


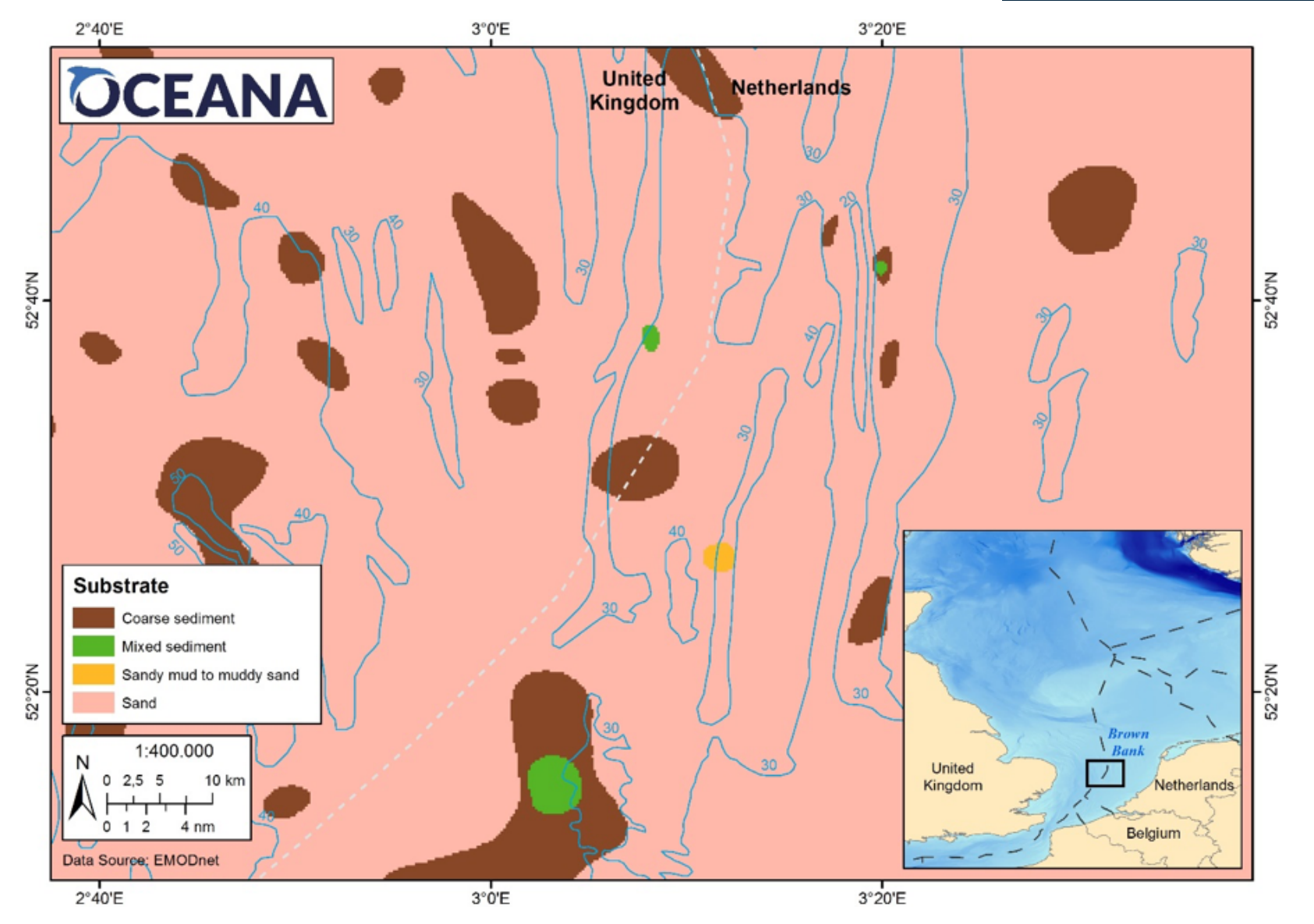

once abundant in Brown Bank, with examples such as Coelodonta antiquitatis, Elephas antiquus, Mammuthus primigenius and Ovibos moschatus. Various specimens have been collected from the area, mainly by fishermen; ${ }^{16}$ in particular, Brown Bank has provided the largest number of records of $C$. antiquitatis of anywhere in Eurasia. ${ }^{17}$

Figure 2. Substrate types and bathymetry of Brown Bank.

KnOWN ECOLOGical FEATURES OF INTEREST

B rown Bank is a recognised area of ecological interest, due primarily to the high recorded abundance of cetaceans and seabirds in the area.

Studies by both Dutch and UK authorities and institutes have found that Brown Bank supports a high concentration of harbour porpoises. ${ }^{18,19,20,21}$ Furthermore, over the past 15 years a shift has been observed in the distribution of harbour porpoise from the northern North Sea into more southerly waters (including Brown Bank), highlighting the importance of this area for this species.

Aerial surveys in Dutch waters have documented the presence of harbour porpoise throughout the year, with especially high densities (up to five individuals per $\mathrm{km}^{2}$ ) during summer. ${ }^{20}$ Although harbour porpoise is a highly migratory species, the highest year- 
round densities in Dutch waters (0.5-3 animals $\left./ \mathrm{km}^{2}\right)$ have been found in the area from Brown Bank to Borkum Stones (on the Dutch/German border). ${ }^{20}$ High concentrations of harbour porpoises have also been observed on the UK side of Brown Bank. ${ }^{21}$ Modelled distribution of this species on the EU Atlantic continental shelf, based on observations from the SCANS-II cetacean survey, predicted densities of 0.6-0.8 individuals $/ \mathrm{km}^{2}$ in Brown Bank, and showed that densities had increased in the area from 1994-2005. ${ }^{22}$

The Dutch side of Brown Bank has been identified as a general biodiversity hotspot for marine mammals on the Dutch continental shelf, not only with regard to harbour porpoises, but also because of the presence of white-beaked dolphins, grey and harbour seals. An assessment aimed at identifying such hotspots found that Brown Bank scored the highest values of any area on the Dutch continental shelf for marine mammals, based on a combination of metrics related to factors such as distribution, density, rarity, and resilience. ${ }^{18}$

The Dutch waters of Brown Bank are also a recognised area of importance for seabirds in the North Sea, particularly in winter. ${ }^{4,5,23}$ On this basis, the government of the Netherlands has identified Brown Bank as being a 'potentially ecologically valuable' area. Specifically, its waters support high numbers of common guillemot (Uria aalge) and razorbill (Alca torda), equivalent to more than $1 \%$ of the relevant biogeographical population; it therefore meets the requirement for being designated as protected under the Birds Directive. ${ }^{23,24}$ Four additional species (gannet (Morus bassanus), lesser black-backed gull (Larus fuscus), great black-backed gull (L. marinus), and kittiwake (Rissa tridactyla)) meet a second criterion, of having more than $0.1 \%$ of their biogeographical population within the boudaries of the area. ${ }^{5}$ All of the above species, together with wintering northern fulmars (Fulmaris glacialis) and herring gulls (L. argentatus) bring the seabird population numbers in Brown Bank to more than 20000 individuals. ${ }^{5}$ Based on these three different standards, Brown Bank clearly qualifies as an Important Bird Area to be listed under the Birds Directive.

In contrast to pelagic species in the area, relatively less is known about the benthos in Brown Bank. Surveys in 1992-1993 identified that the area was characterised by relatively higher densities and diversity of certain meiofaunal groups (e.g., Copepoda, Gastrotricha, Turbellaria, Hydrozoa and Tardigrada) than elsewhere on the Dutch continental shelf, while the macrobenthos comprised a typical coarse sand assemblage. ${ }^{15}$ However, these data were based only on box-corers, and so were not likely to provide 
a complete overview of benthic biodiversity in the area. ${ }^{2}$ A 2011 overview of the benthic biodiversity value of Brown Bank, based on available data from box-corers and dredges, indicated that the area showed that the evenness of macrobenthos was moderately high in the area, but scored low for other benthic biodiversity metrics. ${ }^{18}$

Finally, Brown Bank (and the Southern Bight more broadly) is known to be an area that provides essential fish habitat (EFH) for a variety of commercial fish species. EFH are areas with certain ecological and/or physical characteristics that play a crucial role for the survival or replenishment of a fish stock at a specific life stage, such as spawning, nursery, or feeding grounds. In the case of Brown Bank, spawning grounds have been documented for species that include cod (Gadus morhua), herring (Clupea harengus), mackerel (Scomber scombrus), sandeels (Ammodytidae), sprat (Sprattus sprattus), plaice (Pleuronectes platessa), sole (Solea solea), and whiting (Merlangius merlangus).,25,26 Nursery areas in the Brown Bank area have been recorded for mackerel, sandeel, sprat, and whiting. ${ }^{7,26}$

Si ince 1987, at least 19 marine research survey programmes have been carried out in the Brown Bank area (Table 1). Most of these surveys have concentrated on charismatic species of cetaceans (e.g., harbour porpoise Phocoena phocoena) or seabirds (e.g., common guillemot Uria aalge), and additional research has focused on human activities (e.g., fisheries, navigation safety). Only four studies or programmes have addressed benthic ecology, despite the known general importance of the area for marine biodiversity, and most knowledge of the benthos has been derived from box-corers, dredges, and grab samples from a limited number of stations in the area, in the context of broader-scale studies. The most recent published field study that focused in detail on the diversity of benthic fauna in Brown Bank dates back to $1994 . .^{15}$ 
Table 1. Overview of previous marine research survey programmes carried out in the Brown Bank area.

\begin{tabular}{|c|c|c|c|}
\hline INSTITUTE OR PROGRAMME & YEAR & $\begin{array}{l}\text { BROWN } \\
\text { BANK } \\
\text { WATERS }\end{array}$ & DESCRIPTION/AIMS \\
\hline \multicolumn{4}{|l|}{ Archaeology } \\
\hline $\begin{array}{l}\text { University of Bradford, Ghent University } \\
\text { and Flanders Marine Institute }\end{array}$ & 2018 & NL & $\begin{array}{l}\text { Examination of evidence of prehistoric human } \\
\text { activity in Brown Bank, through geophysical } \\
\text { survey and sediment core examination }{ }^{27}\end{array}$ \\
\hline \multicolumn{4}{|l|}{ Benthos } \\
\hline $\begin{array}{l}\text { Delft University of Technology (TUDelft), } \\
\text { University of Groningen (RUG), Nether- } \\
\text { lands Institute for Sea Research (NIOZ), } \\
\text { and the North Sea Foundation, under the } \\
\text { DISCLOSE project }\end{array}$ & $\begin{array}{l}\text { 2017- } \\
\text { Present }\end{array}$ & NL & $\begin{array}{l}\text { Study of vulnerable habitats in the Dutch } \\
\text { North Sea, using a combination of methods, } \\
\text { including acoustic mapping, cameras, box- } \\
\text { corers and Sediment Profile Imagery }{ }^{28}\end{array}$ \\
\hline $\begin{array}{l}\text { NIOZ and Netherlands Institute for Ecol- } \\
\text { ogy, Centre for Estuarine and Coastal } \\
\text { Ecology (NIOO-KNAW), under the MIL- } \\
\text { ZON-BENTHOS II project }\end{array}$ & $\begin{array}{l}1992- \\
1993\end{array}$ & $\mathrm{NL}$ & $\begin{array}{l}\text { Study of the spatial distribution of zoobenthos } \\
\text { in western Dutch waters, },{ }^{15} \text { using box-corers }\end{array}$ \\
\hline $\begin{array}{l}\text { ICES North Sea Benthos Project (multiple } \\
\text { research institutes from France, Germa- } \\
\text { ny, Netherlands, UK) }\end{array}$ & $\begin{array}{l}1986 \\
2000\end{array}$ & NL, UK & $\begin{array}{l}\text { Study of the macrobenthic fauna in the North } \\
\text { Sea, through grabs and box-corers. Fourteen } \\
\text { years later, some stations were revisited to } \\
\text { compare outcomes and conduct a descriptive } \\
\text { evaluation of the macrozoobenthos communi- } \\
\text { ties, assessing bottom-trawling effects }\end{array}$ \\
\hline \multicolumn{4}{|l|}{ Cetaceans } \\
\hline $\begin{array}{l}\text { Research institutions from Denmark, } \\
\text { France, Germany, Netherlands, Norway, } \\
\text { Portugal, Spain, Sweden, and UK, under } \\
\text { the framework of Small Cetacean Abun- } \\
\text { dance in the North Sea } 3 \text { (SCANS-III) }\end{array}$ & 2016 & NL, UK & $\begin{array}{l}\text { Provision of robust large-scale estimates of ce- } \\
\text { tacean abundance, to inform the } 2018 \text { Marine } \\
\text { Strategy Framework Directive (MSFD) assess- } \\
\text { ment of good environmental status (GES) in } \\
\text { European Atlantic waters }\end{array}$ \\
\hline $\begin{array}{l}\text { Institute for Marine Resources and Eco- } \\
\text { system Studies (IMARES) }, \text { Wageningen } \\
\text { UR }\end{array}$ & $\begin{array}{l}2010- \\
2011\end{array}$ & NL & $\begin{array}{l}\text { Estimation of the distribution, density and } \\
\text { abundance of harbour porpoise on the entire } \\
\text { Dutch continental shelf }{ }^{20}\end{array}$ \\
\hline IMARES, NIOZ & $\begin{array}{l}2008- \\
2010\end{array}$ & $\mathrm{NL}$ & $\begin{array}{l}\text { Investigation of harbour porpoise density and } \\
\text { distribution in Dutch waters }\end{array}$ \\
\hline $\begin{array}{l}\text { Joint Nature Conservation Committee } \\
\text { (JNCC), Joint Cetacean Protocol (JCP) }\end{array}$ & 2009 & UK & $\begin{array}{l}\text { Assessment of key habitat for harbour por- } \\
\text { poise }^{21}\end{array}$ \\
\hline $\begin{array}{l}\text { Research institutions from Belgium, } \\
\text { Denmark, France, Germany, Ireland, } \\
\text { Netherlands, Norway, Poland, Portu- } \\
\text { gal, Spain, Sweden, and UK, under the } \\
\text { framework of Small Cetacean Abundance } \\
\text { in the North Sea } 2 \text { (SCANS-II) }\end{array}$ & 2005 & NL, UK & $\begin{array}{l}\text { Estimation of abundance of cetacean species, } \\
\text { particularly harbour porpoise and common } \\
\text { dolphin, in all EU Atlantic continental shelf } \\
\text { waters }^{22}\end{array}$ \\
\hline $\begin{array}{l}\text { Research institutions from Denmark, } \\
\text { France, Germany, Ireland, Netherlands, } \\
\text { Norway, Sweden, and UK, under the } \\
\text { framework of Small Cetacean Abundance } \\
\text { in the North Sea (SCANS) }\end{array}$ & 1994 & NL, UK & $\begin{array}{l}\text { Identification of concentrations of harbour } \\
\text { porpoise (Phocoena phocoena) and other small } \\
\text { cetaceans in the greater North Sea and Baltic } \\
\text { Sea }^{33}\end{array}$ \\
\hline \multicolumn{4}{|l|}{ Ecosystems } \\
\hline $\begin{array}{l}\text { Rijkswaterstaat, Ministry of Infrastruc- } \\
\text { ture and Water Management and Wa- } \\
\text { geningen Marine Research. National } \\
\text { Surface Water Monitoring Programme } \\
\text { (MWTL) - Monitoring of Marine Waters }\end{array}$ & $\begin{array}{l}\text { 1991- } \\
\text { Present }\end{array}$ & NL & $\begin{array}{l}\text { Long-term annual monitoring programme } \\
\text { across a range of Dutch sites, which was later } \\
\text { combined with the MSFD monitoring pro- } \\
\text { gramme. Surveys include benthic sampling } \\
\text { using box-corers and dredges }{ }^{34}\end{array}$ \\
\hline \multicolumn{4}{|l|}{ Geology/bathymetry } \\
\hline $\begin{array}{l}\text { United Kingdom Hydrographic Office } \\
\text { (UKHO) }\end{array}$ & 2014 & UK & Assessment of navigation safety ${ }^{35}$ \\
\hline
\end{tabular}




\begin{tabular}{|c|c|c|c|}
\hline $\begin{array}{l}\text { Netherlands Institute of Applied Geosci- } \\
\text { ence (TNO) - Geological Survey of the } \\
\text { Netherlands and Rijkswaterstaat }\end{array}$ & 2006 & NL & $\begin{array}{l}\text { Bathymetry and sediment analysis using side- } \\
\text { scan and multibeam sonar data and box-corers } \\
\text { samples to characterise the benthos }{ }^{36}\end{array}$ \\
\hline Deltares & 2003 & NL & Seismic geology study ${ }^{37}$ \\
\hline UKHO & 1995 & UK & Assessment of navigation safety ${ }^{38}$ \\
\hline \multicolumn{4}{|l|}{ Fisheries } \\
\hline $\begin{array}{l}\text { ICES Working Group on Beam Trawl Sur- } \\
\text { veys (WGBEAM) }\end{array}$ & $\begin{array}{l}1990- \\
2017\end{array}$ & NL, UK & Fisheries-independent beam trawl surveys ${ }^{39}$ \\
\hline \multicolumn{4}{|l|}{ Seabirds } \\
\hline $\begin{array}{l}\text { IMARES, on behalf of and financed by } \\
\text { the Ministry of Economy and Climate }\end{array}$ & 2016 & $\mathrm{NL}$ & $\begin{array}{l}\text { Monitoring of common guillemot and razorbill } \\
\text { in Brown Bank, to determine whether conser- } \\
\text { vation objectives for these species were met }{ }^{40}\end{array}$ \\
\hline IMARES & 2014 & $\mathrm{NL}$ & $\begin{array}{l}\text { Assessment of the distribution of common } \\
\text { guillemot (Uria aalge), razorbill (Alca torda), } \\
\text { and their prey fish in the Dutch part of Brown } \\
\text { Bank }{ }^{24}\end{array}$ \\
\hline IMARES & $\begin{array}{l}2009- \\
2012\end{array}$ & $\mathrm{NL}$ & $\begin{array}{l}\text { Assessment of the feasibility of including var- } \\
\text { ious areas (including Brown Bank) within the } \\
\text { Natura } 2000 \text { Network, under the Birds and } \\
\text { Habitats Directives }{ }^{5,23}\end{array}$ \\
\hline European Seabirds at Sea (ESAS) & $\begin{array}{l}1987- \\
1994\end{array}$ & $\mathrm{NL}$ & Seabird research ${ }^{2}$ \\
\hline
\end{tabular}

a Now known as Wageningen Marine Research (WMR). he North Sea is one of the most productive, yet also one of the busiest seas in the world. In addition to its biodiversity value, this sea is also of significant socio-economic value due to its fisheries, oil and gas extraction, harbours, and other industry. Bordered by eight highly industrialised countries (Belgium, Denmark, France, Germany, the Netherlands, Norway, Sweden and the United Kingdom), and with more than 500 people per $\mathrm{km}^{2}$ inhabiting coastal areas, ${ }^{41}$ the North Sea marine ecosystem is highly disturbed and altered by human intervention. Centuries of fishing activity have directly affected marine biodiversity in the area, ${ }^{42,43,44}$ with losses in biomass, particularly of large fish$\mathrm{es},{ }^{45}$ and resulting changes in ecosystem structure, as well as habitat damage caused by destructive fishing gear. Other anthropogenic activities place additional pressure on North Sea marine life, cause disturb and damage habitats, and overlap with areas that should potentially be protected for their biodiversity value. These threats include pollution, eutrophication, oil and gas platforms, wind energy parks, maritime shipping, the laying of cables and pipelines, coastal development, sand and gravel extraction, military training, and recreational activities.

In the Dutch waters of the North Sea, including in Brown Bank, resource exploitation and competition for space are both intense - and demand for space has been increasing. ${ }^{46}$ The main threats 


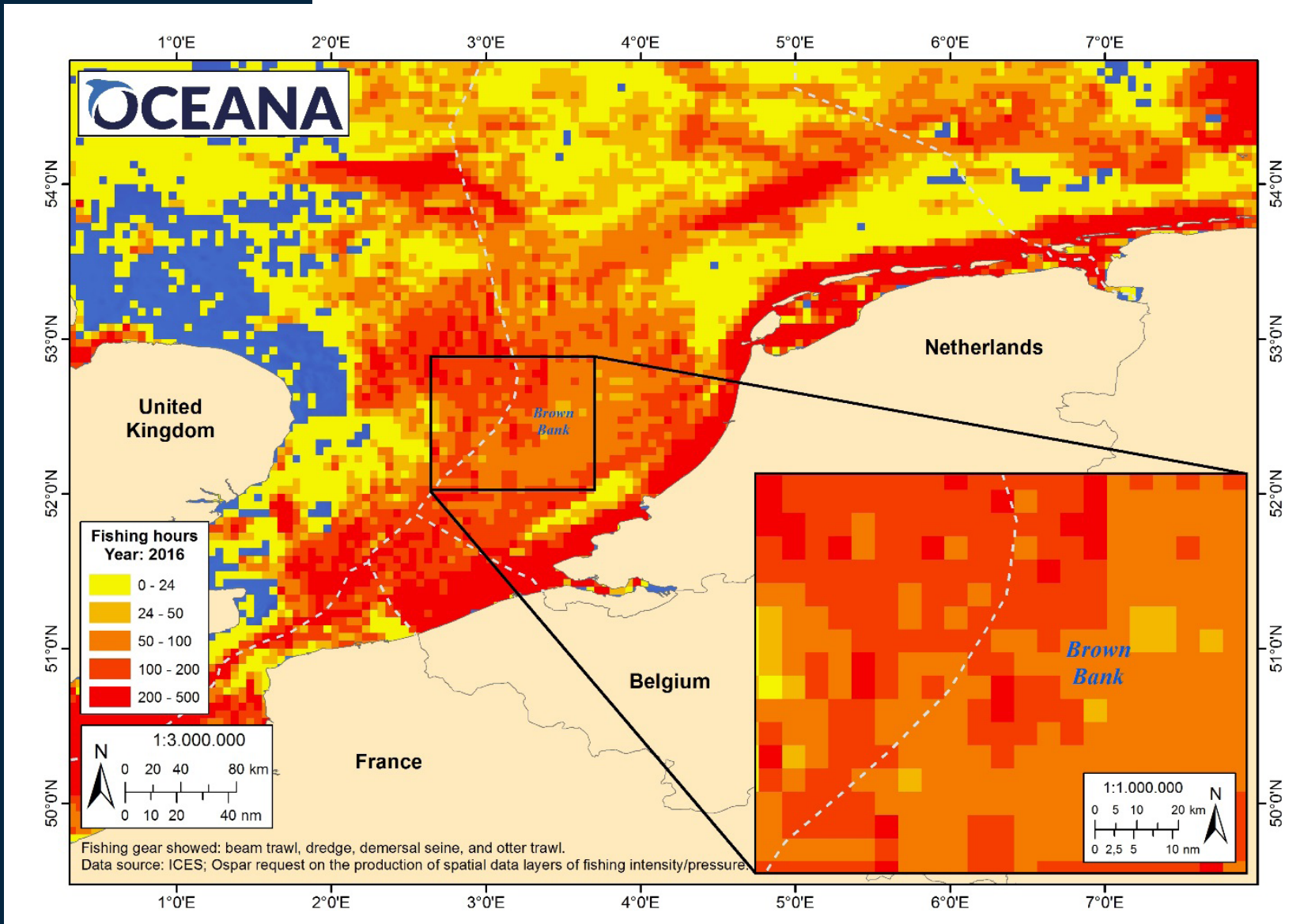

Figure 3. Fishing hours by bottom-contact gears in 2016. Adapted from ICES (2017)..$^{51}$ to biodiversity and ecosystems in Brown Bank include fishing activity, wind energy development, oil and gas exploitation, and ship traffic; each of these is described in more detail below. Additional threats include other types of infrastructure development. For example, the seabed in the Oceana survey area is traversed by seven telecommunications cables and 26 pipelines.

Brown Bank lies at the centre of the ICES 'Southern North Sea' Division (IVc), an area of intensive fishing activity (Figure 3), particularly for demersal species. ${ }^{47}$ Fishing in the area is carried out by fleets belonging to Belgium, Denmark, France, Germany, the Netherlands, and the UK, using a variety of gear-types, as outlined below. $48,49,50$

The dominant fishery operating in the waters of Brown Bank, in terms of vessel numbers, landings, and value, is carried out by large beam trawlers. These vessels, with engine power of up to roughly $2000 \mathrm{hp}$ and codendmesh sizes of $70-99 \mathrm{~mm}, 7,52 \mathrm{pri}-$ marily target sole (Solea solea) and plaice (Pleuronectes platessa), and also capture other fishes, such as turbot (Scophthalmus maximus), brill (Scophthalmus rhombus), cod (Gadus morhua), and skates. The majority of these vessels are Dutch (including Dutch- 
owned beam trawlers that are registered within the German and UK fleets)..$^{53}$ These vessels exert a considerable fishing effort in Brown Bank, often exceeding a total effort of 300000 kw*days during each quarter. ${ }^{52}$ Belgian beam trawlers also fish in the area of the Brown Bank, although to a lesser extent than their Dutch counterparts. ${ }^{48}$

Beam trawlers tow two nets of up to $12 \mathrm{~m}$ width, both of which are by supported by a rigid framework that holds the mouths of the trawl nets open as they move over the seabed. Several different gear configurations are used, and the fishery has been undergoing a progressive transition in recent years. ${ }^{47}$ Traditional beam trawls (used by part of the Dutch fleet, and by Belgian and UK beam trawlers) ${ }^{53}$ use a series of 'tickler' chains to disturb flatfish, so that they rise upward from the seabed and into the path of the net. Newer pulse trawls, which use electrical stimuli to immobilise sole and thereby facilitate their capture, have been increasingly used by the Dutch fleet (including Dutch-owned but German- and UK-registered vessels) since 2009. ${ }^{54}$

Both types of large beam trawlers raise serious concerns about their impacts on benthic species. Traditional beam trawling has been shown to negatively affect biodiversity and biogenic reefs, mainly due to the direct physical impacts of the tickler chains on the seabed. For example, a metastudy based on the combined information from 18 studies showed that an average of 23 species was lost from a system as an effect of beam trawling. ${ }^{55}$ Intensive beam trawling has been found to cause dramatic reductions in infaunal and epifaunal biomass, ${ }^{56}$ and adverse effects are greatest on biogenic reefs. ${ }^{44,57}$ Meanwhile, the use of pulse trawling gear remains highly controversial. Although the impacts of direct mechanical disturbance on the seabed are less severe with pulse trawls than with traditional beam trawls, there are considerable uncertainties about the impacts of electrical stimulation on non-target benthic species and habitat. ${ }^{54}$ As a result, pulse trawling remains the focus of ongoing policy discussions at the level of the EU. ${ }^{58}$

A range of other fisheries employ demersal towed mobile fishing gear in Brown Bank, and so are also likely to have significant negative impacts on benthic biodiversity. These fisheries operate on a smaller scale than the large beam trawl fishery, and include:

- Small Dutch or Belgian beam trawlers (with engine power below $300 \mathrm{hp}$ ), which target flatfish and/or brown shrimp, Crangon crangon. Most of these vessels use traditional beam trawl gear with tickler chains, but some use pulse trawls. ${ }^{54}$ 
- Dutch and Belgian vessels that fish with Danish/Scottish seines (also known as 'flyshooters'); Brown Bank is one of the main areas on the Dutch continental shelf for this fishery. ${ }^{7}$

- Dutch, Belgian, French, German, and UK demersal trawlers other than beam trawlers (e.g., otter trawlers). ${ }^{49,50}$

- German demersal seiners. ${ }^{49}$

As with beam trawls, demersal trawls and seines are gear types with recognised high impacts on benthic ecosystems, with effects ranging from direct mortality of organisms due to physical disturbance, to broader-scale changes in habitats. ${ }^{59}$ In the case of the flyshoot fishery, no empirical studies have focused on its specific impacts, but it is believed to have adverse effects on fragile biogenic habitats. ${ }^{60}$

In addition to mobile benthic gears, other fishing activities in Brown Bank include the use of pelagic trawls and fixed nets (by Danish,

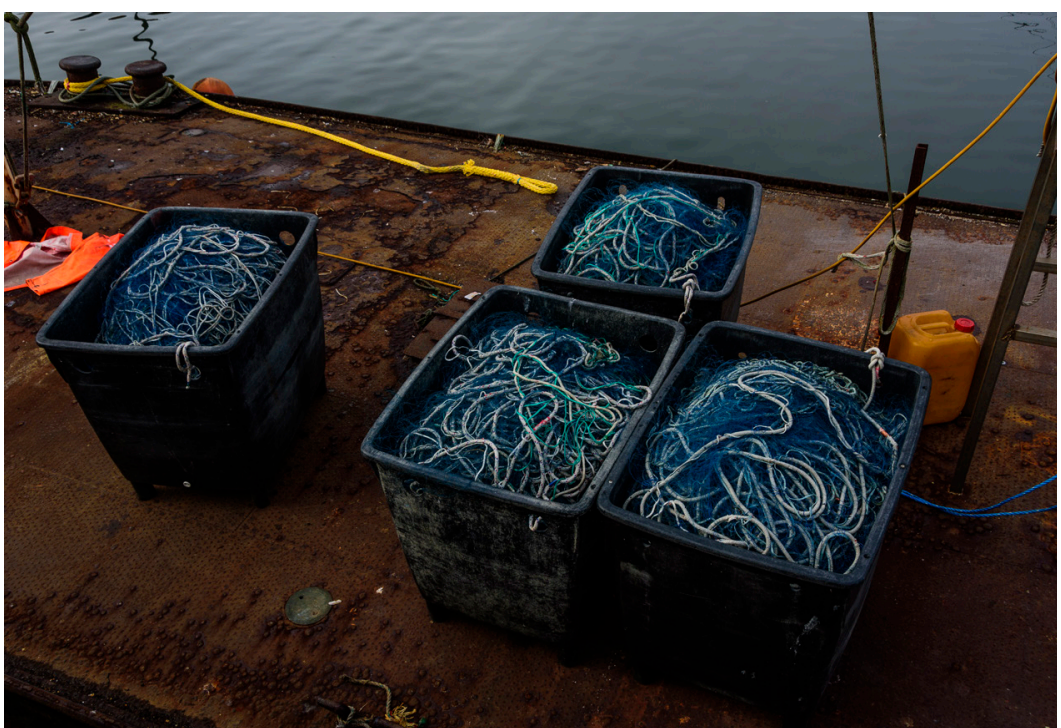

Dutch, French, German, and UK vessels). ${ }^{49,50,61}$ Of these fisheries, one that has raised concerns about its potential biodiversity impacts in Brown Bank is the gillnet fishery, given the associated risk of common guillemots and razorbills becoming entangled while foraging. A study commissioned by the government of the Netherlands estimated the fishing intensity of the Dutch, Danish, and German gillnet fisheries to be between 892 and 1619 km-net-days per year (based on VMS and logbook data). ${ }^{5,62}$ Although the specific bycatch probability could not be estimated for the two seabird species, the study concluded that mitigation measures may be necessary in the case of the common guillemot, given its deeper diving behaviour and its overlap with the distribution of the gillnet fishery.

WIND ENERGY DEVELOPMENT

The government of the Netherlands has committed to substantially increasing its renewable energy production from offshore wind farms from $950 \mathrm{MW}$ to $4450 \mathrm{MW}$ by 2023 , and to $11.5 \mathrm{GW}$ by $2030 .{ }^{63}$ The specific areas intended for wind energy development under these plans represent a potential threat to Brown Bank (Figure 4), and conflict with the potential designation of Brown Bank 
as an MPA under the Birds Directive, which was due to have been decided in 2016.64 This decision has not yet been made, yet at the same time, part of Brown Bank has also been designated as a potential area for wind energy development. Specifically, the northern part of the Dutch side of the bank overlaps with IJmuiden Ver, a commissioned large offshore wind energy development area, with a planned capacity of $4 \mathrm{GW} .{ }^{65,66}$ The development of IJmuiden Ver wind farm will likely have significant negative effects and cause habitat loss for seabirds, cetaceans and benthic fauna in Brown Bank. ${ }^{5}$ Although the Dutch government's recent Offshore Wind Energy Roadmap 2030 states that "part of the southern side" of the IJmuiden Ver area will not be used for wind farms, "given the (potential) designation of the partially overlapping "Bruine Bank" area as a Natura 2000 area," ${ }^{3}$ it is not indicated to what extent this overlap will be avoided. A second wind farm include in the same plans lies on the eastern edge of Brown Bank; the $1.4 \mathrm{GW}$ Hollandse Kust (west) wind farm is planned to enter the tendering phase in $2021 .^{63}$

In the United Kingdom, growth in offshore wind development is scheduled to increase capacity from $5 \%$ of the nation's total energy consumption, at present, to $10 \%$ by $2020 .{ }^{67}$ Among the new planned areas for wind energy development are two sites that overlap with the Oceana survey area in Brown Bank: the $1.8 \mathrm{GW}$-capacity Norfolk Vanguard wind farm (the application for which is undergoing examination), and the $1200 \mathrm{MW}$-capacity East Anglia THREE wind farm (which has already been authorised). ${ }^{68}$ It is worth highlighting that, despite the plans of the Dutch government to develop wind farms in Dutch waters of Brown Bank, the Netherlands Ministry of Infrastructure and the Environment raised concerns about the impact that proposed UK wind farm projects might have on seabirds in the potential Brown Bank Natura 2000 area. ${ }^{69}$

In addition to the multiple direct threats posed to benthic ecosystems in relation to the construction of wind farms and the installation of associated infrastructure (e.g., cables), it should also be noted that under certain circumstances, an established wind farm may have some benefits for conservation. ${ }^{70}$ For example, in some cases, the prohibition of bottom-contact fisheries within the area of a wind farm may allow for the recovery of certain benthic species.

In the Netherlands, oil and gas are widely exploited, with more than one hundred facilities installed on the seabed, along with their corresponding networks of pipelines. ${ }^{46}$ Currently there is one active gas well in Dutch waters of Brown Bank, in the southeast- 
ern part of the Oceana survey area (Figure 4). Offshore oil and gas production also represents a major industry in the UK, with extensive installations across the North Sea. ${ }^{71}$ Several natural gas extraction sites are located close to the UK side of Brown Bank. For example, the Davy and Davy East gas fields lie approximately $18 \mathrm{~km}$ north of the Brown Bank survey area. ${ }^{72,73,74}$

The North Sea is the most crowded sea in the world, after the South China Sea, in terms of maritime shipping, with the major seaports - Rotterdam, Amsterdam, Antwerp, Hamburg, Le Havre and London - located in the southern area. ${ }^{75,76}$ Up to 260000 ship movements are registered per year in Dutch waters alone..$^{75,76}$ Most of the fleet crossing North Sea waters is non-European flagged ${ }^{76}$ which represents one of the most significant environmental problems associated with this activity: the introduction of non-indigenous species through ballast water and fouling organisms. Other threats to North Sea ecosystems related to intensive shipping are the elevated concentration of contaminants derived from the discharge of waste and the disposal of toxic and hazardous substances (such as oil spills and persistent organic pollutants (POPs)), as well as littering (i.e., loss of cargo), and underwater noise. ${ }^{46}$

In comparison with other major economic sectors, such as fisheries, maritime shipping is characterised by a lag in environmental governance, and relatively less research focused on examining the associated environmental impacts. ${ }^{77}$ However, shipping is known to have varied and multiple impacts on marine biodiversity. For example, cetaceans experience collisions and changes in behavioural responses, such as masking communication and abandoning breathing areas as a result of continuous exposure to shipping traffic and underwater noise, respectively. ${ }^{78}$ Pollutants such as POPs (which have a terrestrial source and are leached to the marine environment through shipping traffic) bioaccumulate in the food web, particularly affecting top predators such as large pelagic fishes and marine mammals, generating endocrine disruptions in marine fauna, and threatening human and environmental health. ${ }^{79}$ Meanwhile, birds are also susceptible to collisions with boats, especially at night, ${ }^{80}$ and busy traffic routes have been found to displace seabirds to other areas. ${ }^{81}$

The Brown Bank area is traversed by one of the main IMO shipping routes in southern North Sea waters (Figure 4) and several other shipping lanes, together supporting an already-high intensity of maritime traffic. ${ }^{76}$ The resulting pressure on ecosystems is likely to increase, particularly given that both the Netherlands and the UK 


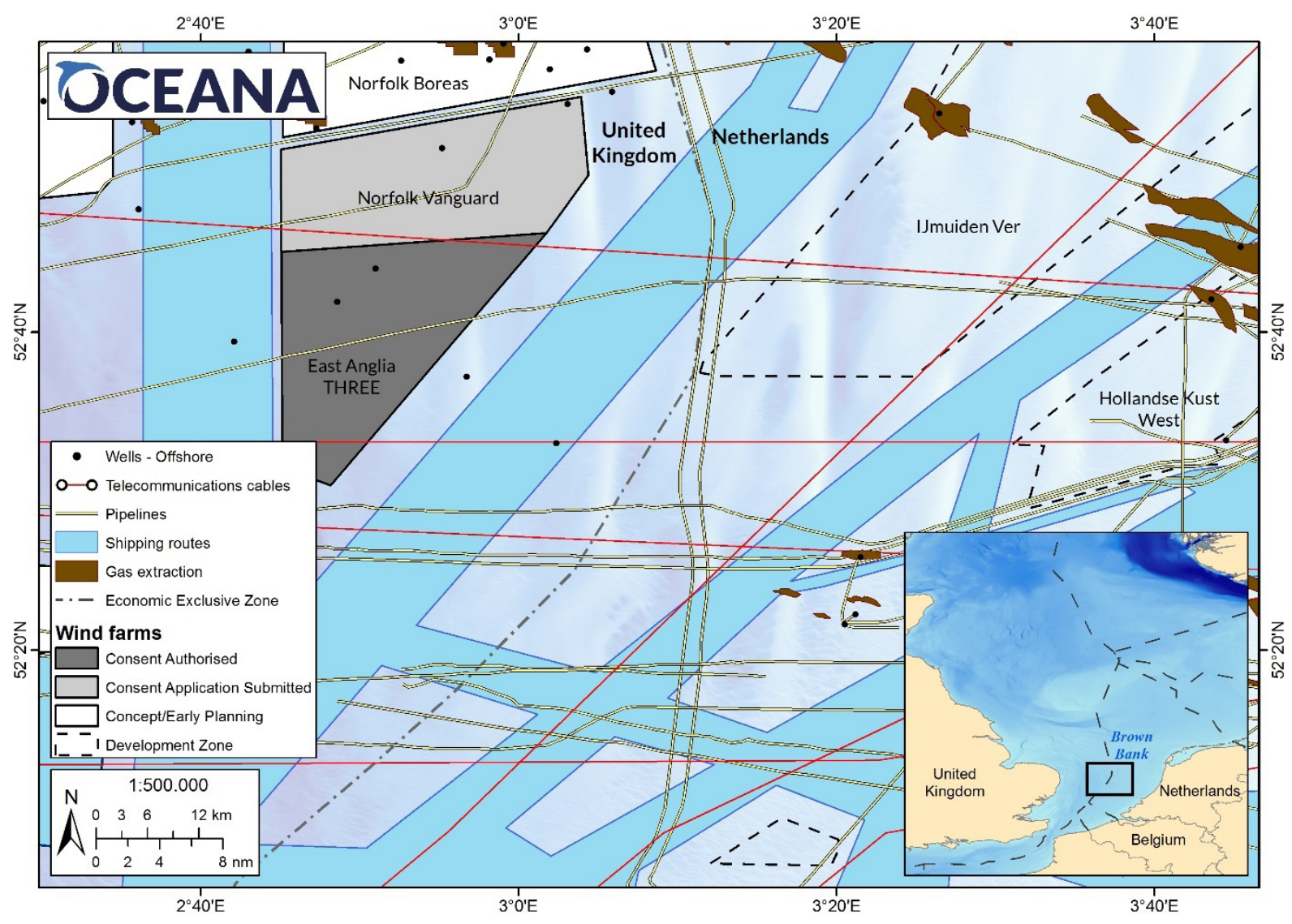

governments have highlighted the importance of maritime shipping to their national economies, and their respective expectations for its growth in the coming years. However, despite the known environmental impacts of shipping activities, neither the Dutch National Water Plan (2016-2021) nor the UK Maritime Growth Study include any specific recommendations, measures, or commitments related to assessing or reducing such impacts, either at present or in the future. ${ }^{64,82}$ In light of the current intensity of maritime traffic in Brown Bank, continued growth in maritime shipping represents a clear threat to the marine species and ecosystems the area supports.

$M$ easures to ensure the protection of biodiversity in Brown Bank are relatively limited. On the Dutch side, no specific measures are in place for the area. In 1990, the Netherlands Ministry of Agriculture, Nature and Food Quality included all Dutch waters in the North Sea ecological network, which implies that the precautionary principle applies to any human activity developed in the area. ${ }^{83} \mathrm{Be}-$ yond this general framework, however, there are no specific management requirements for Brown Bank. The recognition of the area as being ecologically valuable (see Known ecological features of interest) does not imply any management measures for the area. 
The UK side of Brown Bank is already subject to certain management requirements, specifically with respect to harbour porpoise. The United Kingdom included the area within the Southern North Sea candidate Special Area of Conservation (cSAC), which was designated in 2017 based on areas of importance for harbour porpoise (Phocoena phocoena). The Southern North Sea cSAC covers an extensive area of $36951 \mathrm{~km}^{2},{ }^{84}$ and overlaps with four other MPAs (both inshore and offshore). Draft advice by JNCC and Natural England on potentially harmful activities in the area identified a range of potential threats to harbour porpoise, and highlighted two activities that pose a high level of risk: bycatch in commercial fisheries (primarily static nets) and pollutants originating from both terrestrial and offshore sources. ${ }^{85}$ Although no management plan is in place yet for the MPA, by law, the UK is nevertheless required to avoid significant disturbance to harbour porpoise in the area, and the deterioration of its habitat. ${ }^{86,87}$

$T_{1}$ he protection of biodiversity in the Dutch part of Brown Bank has been identified as a potential conservation priority for more than a decade. The likely value of the area was first highlighted in 2005 in a government-commissioned study, carried out jointly by IMARES (now Wageningen Marine Research; WMR) and the National Institute for Coastal and Marine Management (RIKZ), which aimed to identify areas on the Dutch continental shelf with special ecological values that should be protected. ${ }^{4}$ The study highlighted the apparent importance of Brown Bank based on the aggregation of species such as greater black-backed gull, herring gull, common guillemot, razorbill, and harbour porpoise in the area. It noted that Brown Bank was likely to qualify for protection, but that more research was needed.

Following this work, Brown Bank began to figure into official government spatial planning options for the North Sea. The Dutch National Water Plan (2009-2015) included it as a "potentially ecologically valuable area" on a map of North Sea spatial policy options, and stated that detailed research would be carried out into the area's "nature values" (Figure 5), in the context of Natura 2000 and the MSFD. ${ }^{88}$ This research was completed at IMARES in 2012, as part of a broader programme to assess whether Brown Bank and other areas (i.e., Borkum Stones, Gas Fountains, and Zeeland Banks) should be protected. The assessment showed that the area clearly qualified for protection under the Birds Directive, with respect to common guillemots and razorbills, and that the potential 
IJmuiden wind farm area could negatively impact on both species. ${ }^{5}$

Despite this conclusion, a decision about the designation of an MPA in Brown Bank has been repeatedly postponed and remains pending. The National Water Plan (2016-2021), which was released in 2016, indicated that a decision would be made regarding the possible designation of the area in 2016.64 This same commitment from the Dutch government was also included in the MSFD Programme of Measures for the Dutch part of the North Sea. ${ }^{89}$ Nevertheless, the decision was not taken in 2016, nor in 2017. By 2018 , the government had become more vague in its commitment regarding Brown Bank. In government documents for the second cycle of the MSFD, the reference to the area indicated simply that the decision on whether to designate it under the Birds Directive would be made "in the coming period" and noted that until that time, the area would retain its 'potentially ecologically valuable' status. ${ }^{90}$

The long-awaited protection of Brown Bank has also been supported by a coalition of Dutch environmental NGOs, such as the North Sea Foundation, ${ }^{91}$ the Society for the Protection of Birds (Vogelbescherming Nederland; VBN), ${ }^{92}$ and WWF. ${ }^{93}$ In July 2018, VBN formally requested that the Dutch government proceed with the designation of the area under the Birds Directive, and that it release scientific reports relevant to the biodiversity value of the area, as well as advancing with research to determine the value of other areas of potential importance for birds in Dutch waters. ${ }^{92}$ VBN has since initiated legal proceedings against the government.

Figure 5. Proposed Brown Bank Natura 2000 site under the Birds Directive (in green), adapted from the Dutch National Water Plan (2016-2021). ${ }^{64}$ The UK candidate SAC Southern North Sea is also shown.

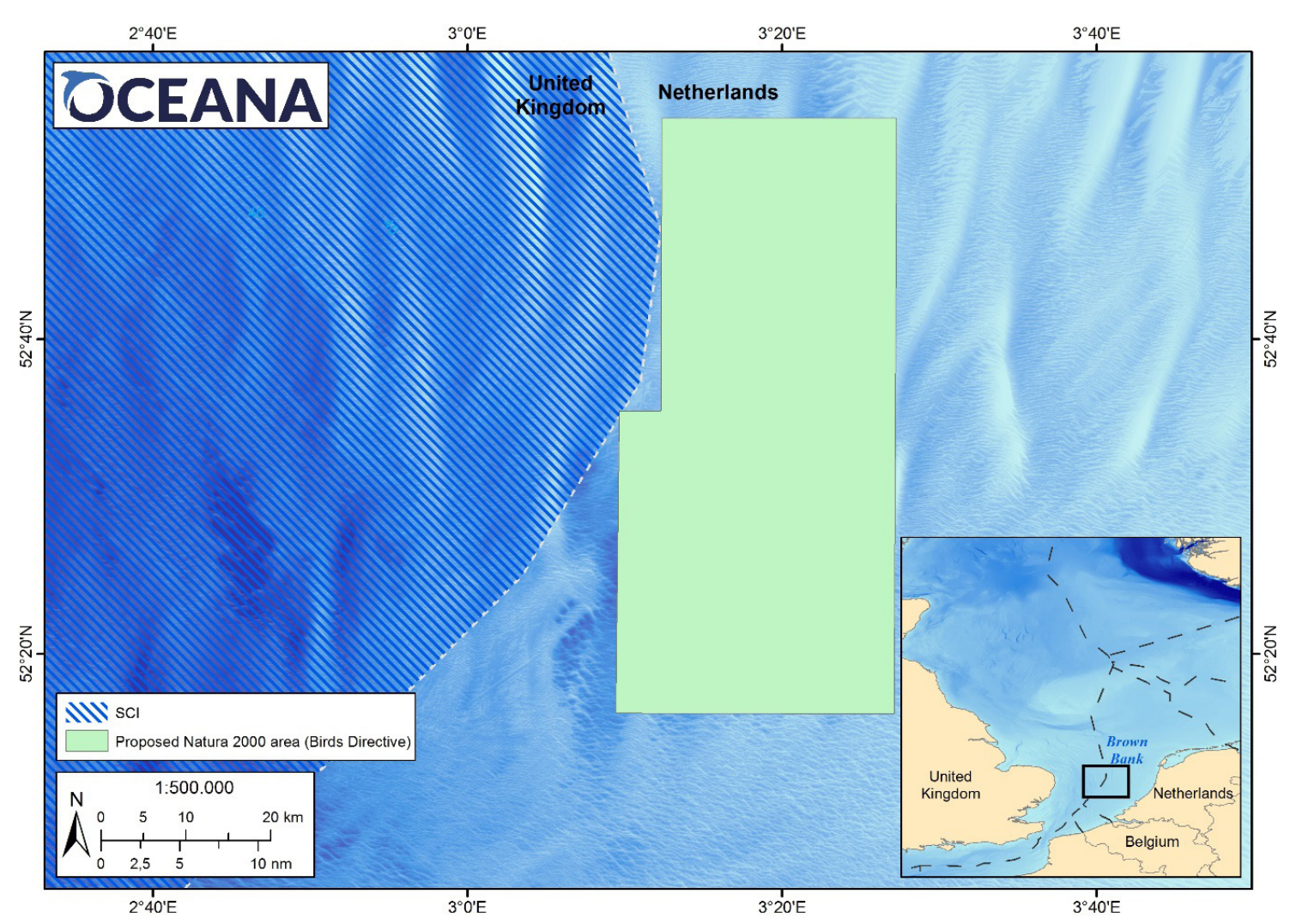




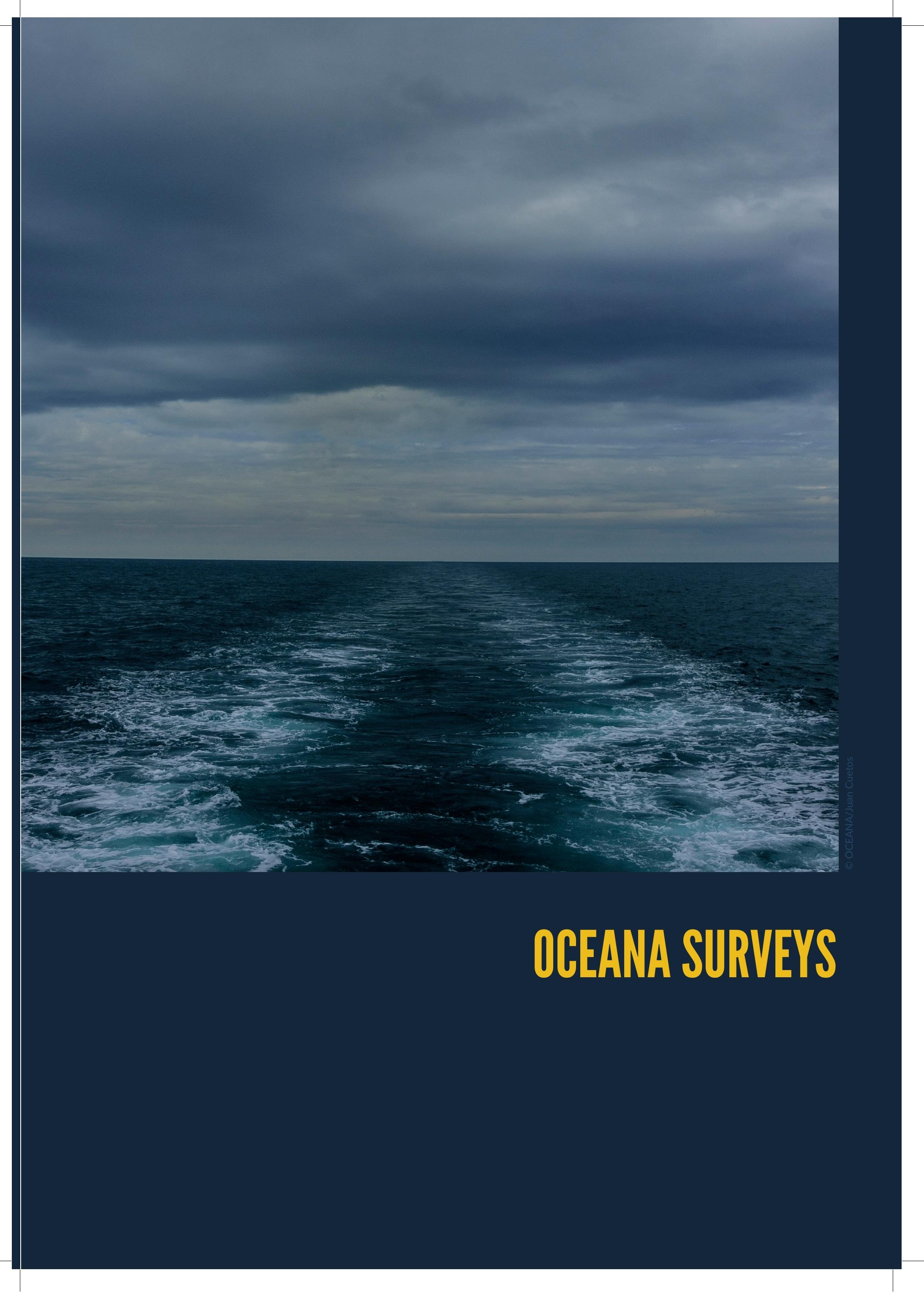


$\mathrm{O}$ ceana surveyed Brown Bank as part of two eight-week, atsea research expeditions carried out across the North Sea in 2016 and 2017. These expeditions aimed to gather first-hand information from areas of known or potential ecological importance, but from which data on benthos were lacking. Surveys of these zones were carried out onboard the research survey vessel MV Neptune, a fully-equipped vessel of $49.85 \mathrm{~m}$ overall length and $10 \mathrm{~m}$ extreme breadth.

Surveys of the area were conducted on 12-13 July and 28 August 2016, and on 9-19 July and 14-15 August 2017. In total, seven days were dedicated to Brown Bank, which was one of the few areas surveyed in both years, because of its particular interest for science (Figure 6). Most of the survey effort was focused on the Dutch side, for two reasons. First, a larger proportion of Brown Bank is located in Dutch waters. Second, the 2017 surveys were carried out in collaboration with the DISCLOSE project (see below), which is focused on Dutch waters.

The seabed was explored mostly by visual means, using a remotely operated vehicle (ROV). Infaunal grab sampling was also carried out, as well as sampling of oceanographic parameters using a conductivity, temperature, and depth (CTD) device. Additional survey methods were used in 2017 , in collaboration with the DISCLOSE project (see below).

For ROV image recording, a Saab Seaeye Falcon DR ROV was used, equipped with a high-definition video (HDV) camera of 480 TVL with Minimum Scene Illumination 2.0 LUX (F1.4), Pick Up Device $1 / 2$ " CCD, Image Sensor, and spherical $1 / 2$ of $3.8 \mathrm{~mm}$ and wide-angle lenses. Images were recorded both in high definition and low resolution, while position, depth, course and time were simultaneously documented. Lasers on the ROV were used in order to estimate sizes and abundances. Considering the average speed and the wide angle of the camera (i.e., it was able to film transects of ca. $1.5 \mathrm{~m}$ width), the ROV allowed the observation of around $550-650 \mathrm{~m}^{2}$ per hour of seabed.

A total of 13 ROV transects were surveyed in Brown Bank during both expeditions: eight in 2016 (five in the Netherlands and three in the UK) and five in 2017 (all in Dutch waters). Surveyed sites ranged in depth from 21 to $45.5 \mathrm{~m}$. They were selected based on bathymetric and substrate data and, in 2017, acoustic backscatter data, which provided further information about the characteris- 
tics of the seafloor. Backscatter data were obtained using a Reson Seabat 7125 SV multibeam echosounder (Teledyne Marine), which was operated at a frequency of $200 \mathrm{kHz}$, with a maximum ping rate of $50 \mathrm{~Hz}, 256$ equidistant beams, maximum swath angle

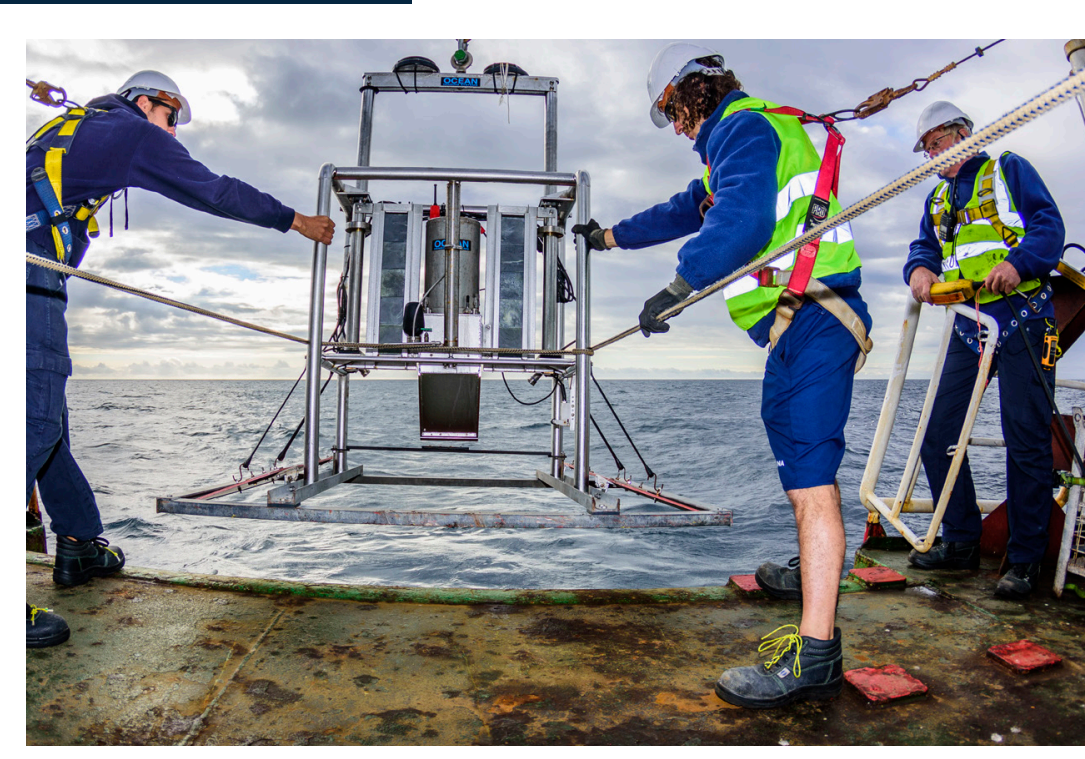
of $128^{\circ}$, and depth resolution of $6 \mathrm{~mm}$. The data were recorded in QINSy and cleaned using Qimera (both from Quality Positioning Services BV).

During and following the expedition, analysis of the footage recorded by the ROV was carried out by Oceana scientists. All of the visible species were identified to the finest taxonomic level possible. Specimens that were collected with the ROV $(n=8)$ to clarify preliminary identification based on the live video feed were also identified to the finest possible resolution.

Benthic infaunal community composition was examined using a 12 L Van Veen grab sampler. A total of 63 grab samples were taken in the Brown Bank survey area: 60 in Dutch waters, and three in UK waters. In 2016, 554 biological specimens were collected from 14 grab samples (11 in Dutch waters, and three in UK waters). These specimens were analysed by Oceana scientists during and after the 2016 expedition; specimens retained on $0.5 \mathrm{~mm}$ and 1 $\mathrm{mm}$ mesh sieves were kept and identified to the finest taxonomic resolution possible. All of the samples collected in 2017 (49 grab samples from 22 sampling points in Dutch waters of Brown Bank) were sent to DISCLOSE collaborators at the Royal Netherlands Institute for Sea Research (NIOZ) for further analysis. The results of those analyses were not yet available at the time of writing this report and are therefore not included here.

During the 2017 expedition, Oceana worked in collaboration with the DISCLOSE project ${ }^{28}$ to carry out surveys in Dutch waters. This project, a partnership between Delft University of Technology, the University of Groningen, NIOZ, and the North Sea Foundation, aims to reveal the distribution, structure and functioning of benthic communities and habitats in the Dutch 
North Sea. Brown Bank is one of the areas of interest for that project. During the 2017 expedition, three DISCLOSE scientists were present on board MV Neptune, and used additional technologies for carrying out benthic surveys: side-can sonar, a towed camera, and a sediment profile imaging device. The results of those surveys will be analysed and published under the framework of the DISCLOSE project.

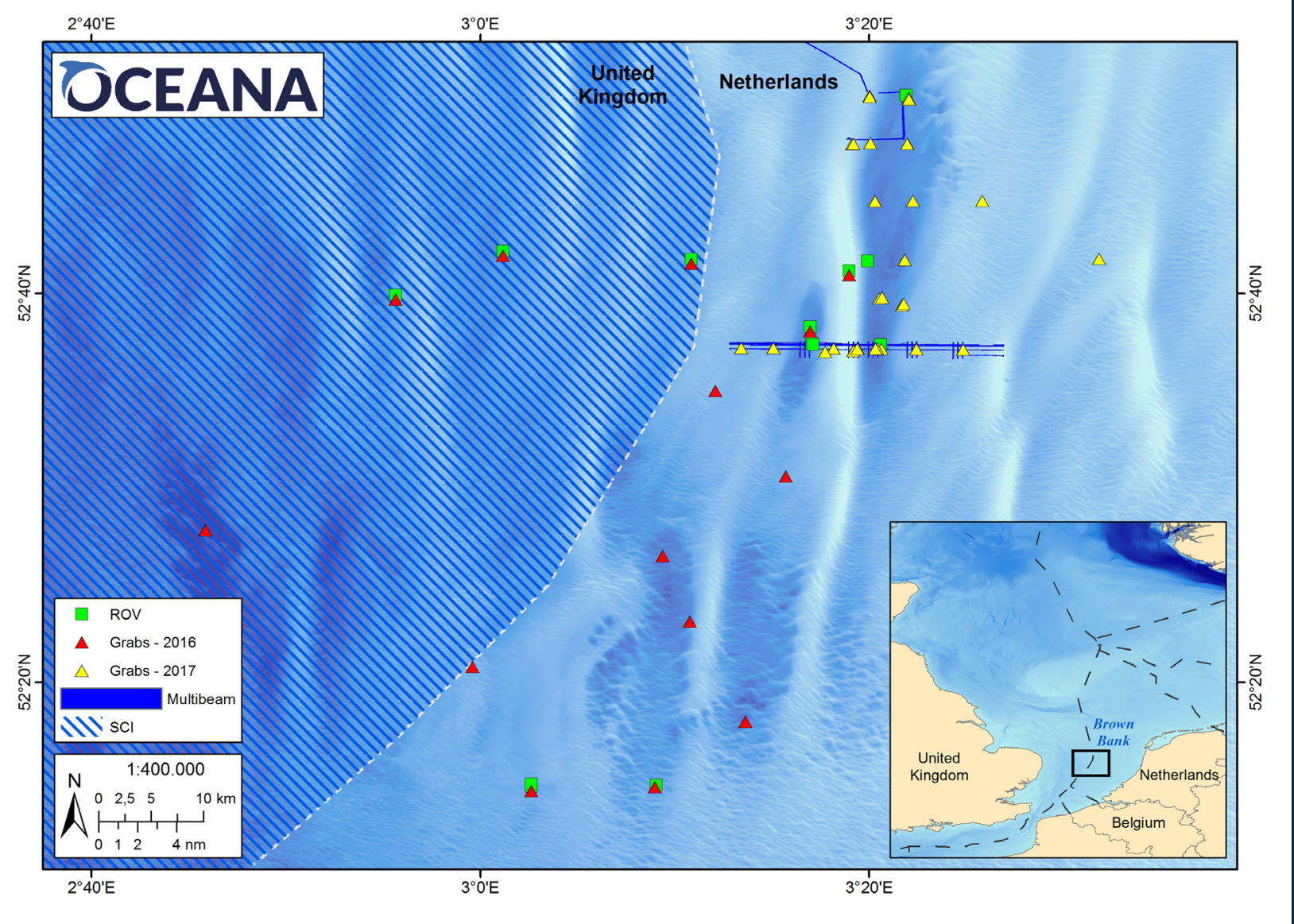

Figure 6. Survey points in Brown Bank during the 2016 and 2017 Oceana North Sea expeditions. Points are shown according to sampling type (i.e., ROV, grab samples, and multibeam echosounder). Grab samples are shown by survey years; data from the 2016 grab samples are included in this report, while 2017 samples were collected in collaboration with the DISCLOSE project, and the results were not yet available at the time of writing. 

Din Brown Bank, of which 134 were identified to the species level, and 70 to higher levels (see Annex). A total of 103 taxa of invertebrates (including 95 species) were documented from the area. A total of 41 fish taxa (including 30 species) were recorded during the expeditions, including two chondrichthyans.

Hard substrates (e.g., rocks and wrecks) were dominated by filtrating organisms such as hydrozoans and sea anemones, with a total of 28 taxa of cnidarians documented, 21 of which were identified to species level. Soft and sandy sediments were inhabited primarily by burrowing and epibenthic organisms, including molluscs, crustaceans, echinoderms, and to some extent, the biogenic engineering species Sabellaria spinulosa. Fourteen species of macroalgae were also observed in the area, although most of them were observed unattached, at depths of less than $30 \mathrm{~m}$. In addition, two small cetaceans were observed from the ship, as was the carcass of a minke whale (Balaenoptera acutorostrata).

Detritic sandy bottom was found during all of the ROV surveys in Brown Bank, although with some variations in the specific type across the locations studied. In order of predominance, the three community types found were: i) detritic sandy bottom with shell remains; ii) Sabellaria spinulosa aggregations and reefs on soft bottoms; and iii) artificial substrata (wrecks) covered by invertebrates on detritic sandy bottom with shell remains. All three of these community types were documented in Dutch waters of Brown Bank (Figure 7). In contrast, in UK waters, only detritic sandy bottoms with shell remains were observed. Isolated aggregations of S. spinulosa tubes were present at the four locations surveyed on the UK side of the study area; these tubes were documented during ROV surveys in three of the four sampling sites and were collected in grab samples in two of the four sampling sites. No wrecks or biogenic reefs were documented in UK waters, possibly due to the relatively lower number of surveys that were carried out on this side of the bank.

A detailed description of each of the three community types is provided below. 


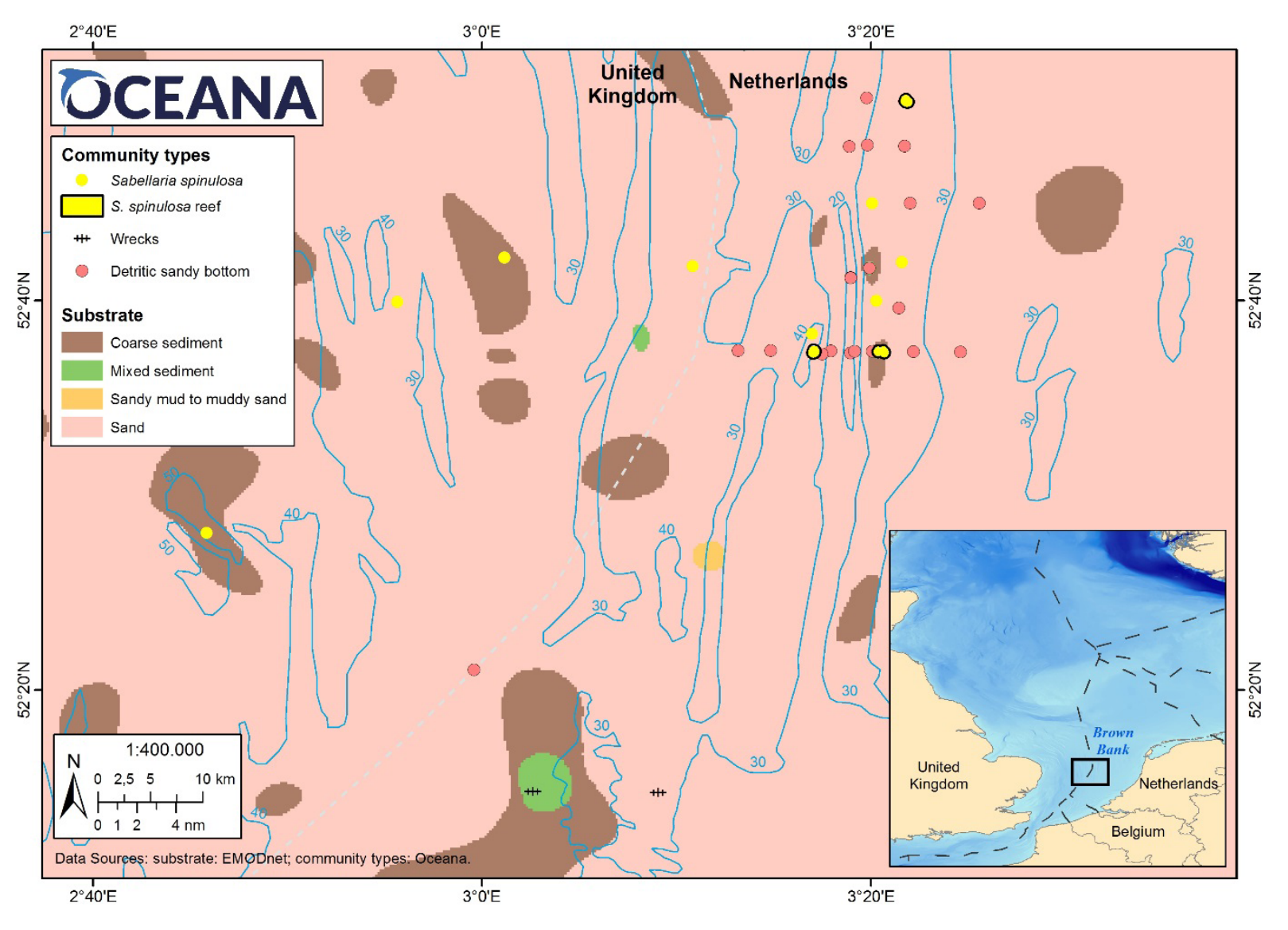

\section{DETRITIC SANDY BOTTOM WITH SHELL REMAINS WITH OCCASIONAL PEBBLES}

[EUNIS code: A5.44: Circalittoral mixed sediments]

On the Dutch side of Brown Bank, the most notable species found on detritic sandy bottom (due to their relatively high frequency of occurrence) were the echinoderms Asterias rubens and Ophiura ophiura, the hydrozoan Hydractinia echinata, the crustacean Pagurus bernhardus and the annelid Lanice conchilega, commonly known as the sand mason worm. Few species of fishes were recorded: common dragonet (Callionymus lyra), spotted dragonet (Callionymus maculatus), goby (Pomatoschistus sp.), and dab (Limanda limanda) among other flatfish species, and one elasmobranch, thornback ray (Raja clavata) (Figure 8). The main species found in the eleven grab samples taken from this area were molluscs (23 identified species), together with echinoderms (mainly Echinocyamus pusillus and some ophiuroids), and crustaceans such as amphipods (e.g., Bathyporeia sp.) and copepods.

On the UK side, on detritic sandy bottom, fishes such as gurnards (various species) and flatfishes were common along the transects surveyed, as well as echinoderms. The substrate was a mixture of sand and shell gravel. Several types of echinoderms were found on this substrate, especially serpent star (Ophiura 
ophiura), and common sea star (Asterias rubens), together with sea urchins such as Brissopsis sp. and Spatangus purpureus. In

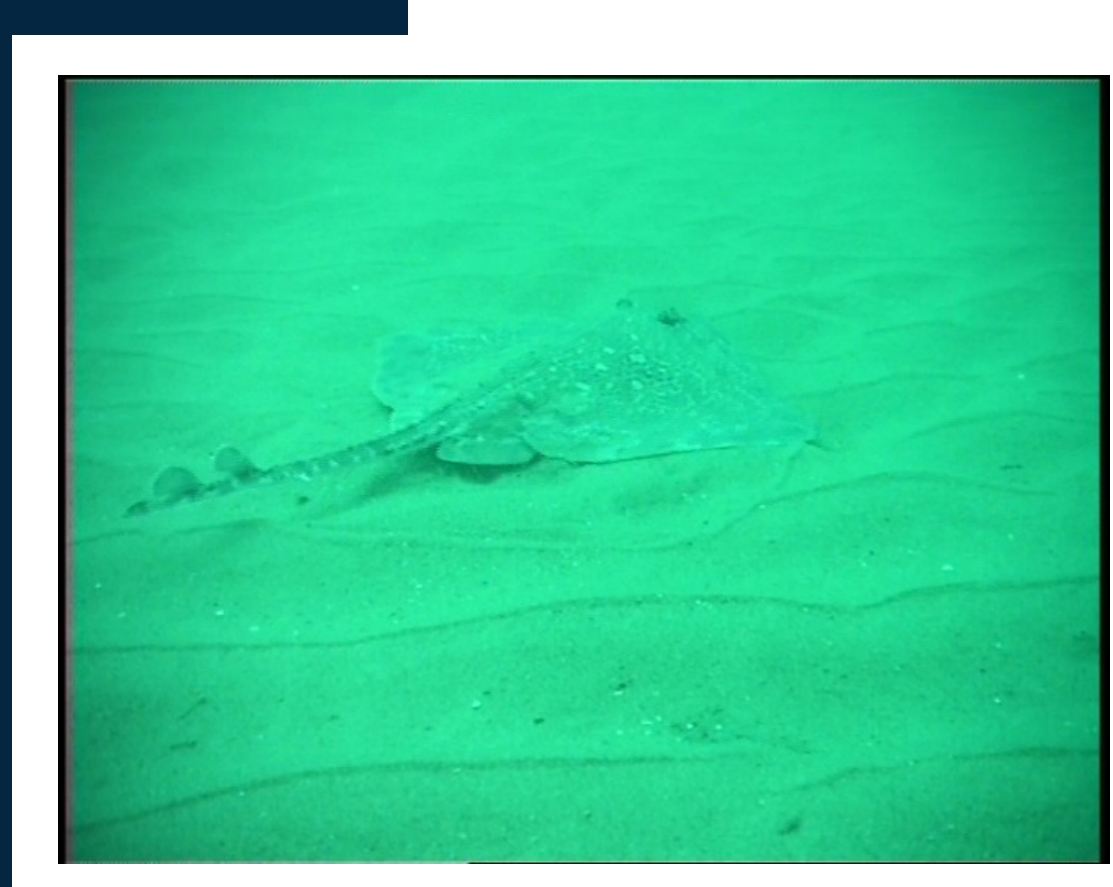

some areas, the shell gravel was larger in size, with some small stones present. In those places, crustaceans such as blueleg swimming crab (Liocarcinus depurator) and velvet swimming crab (Necora puber), and some sessile species such as ringed tubularia (Ectopleura lar$y n x)$ found refuge or a surface to colonise. In the four grab samples taken in these waters, three of which coincided with the three ROV transects carried out on the UK side, banded wedge-shell (Donax vittatus) was the most abundant species

Figure 8. Raja clavata on detritic sandy bottom in Dutch waters of Brown Bank. found, together with other molluscs such as necklace shell (Euspira catena) and elliptical trough shell (Spisula elliptica).

On two occasions, small areas with pebbles were found on this type of bottom (Figure 9). In these areas, the species found did not differ from those found along the other transects in the area.

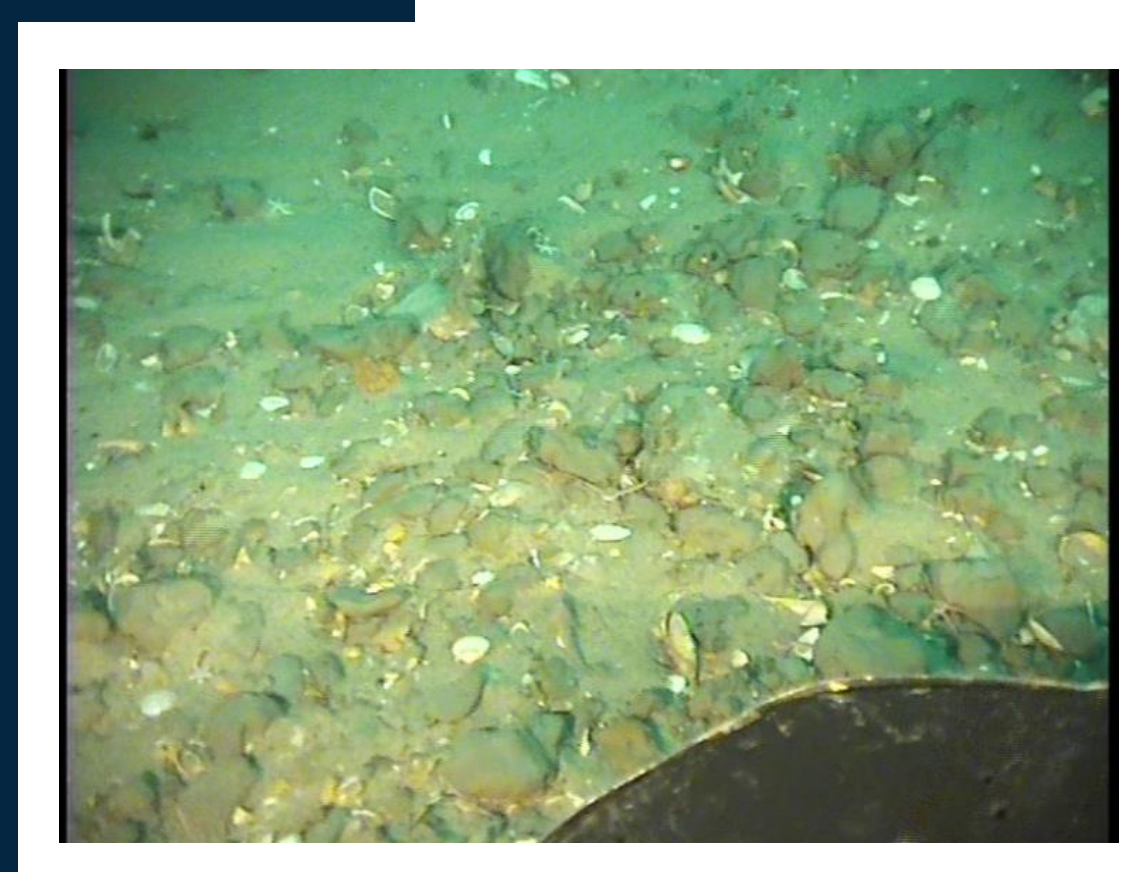

SAbelLaria SPINULOSA

AGGREGATIONS AND REEFS ON

SOFT BOTTOM

[EUNIS code: A5.611 Sabellaria spinulosa on stable circalittoral mixed sediment]

The presence of the ross worm (Sabellaria spinulosa), a sedimentary polychaete, was recorded in 11 locations in Brown Bank: seven in Dutch waters and four in UK waters.

S. spinulosa is known as a habitat engineer, due to its ability to aggregate in colonies of thou-

Figure 9. Sand with shell remains and pebbles. sands of individuals, effectively forming biogenic reef structures that provide habitat and settlement area for a multitude of species. ${ }^{94,95}$ Biogenic reefs are known to increase ecosystem biodiversity, biomass and stability. ${ }^{96}$ In the UK, biogenic reefs created 
by polychaetes such as $S$. spinulosa have become the subject of intense conservation focus. In 2007, the Joint Nature Conservation Committee (JNCC) developed criteria for identifying areas where S. spinulosa aggregations could be categorised as reefs, with the aim of informing their protection. ${ }^{97}$ Those criteria have since been used as the basis for mapping reef areas in UK waters, and S. spinulosa reefs are one of the 'Features of Conservation Importance' that are prioritised for protection within the network of Marine Conservation Zones. ${ }^{98}$

In three locations where S. spinulosa was present (all of which were in Dutch waters), the polychaete tubes had formed such extensive aggregations that they constituted biogenic reefs (Figure 10), using the definition of the OSPAR Convention. According to those criteria, such reefs are defined when coverage is more than $30 \%$ in mixed substrata ( $50 \%$ on hard bottoms), and thick enough to support associated fauna distinct from the surrounding area. ${ }^{99}$ Based on this definition, an area of $1023 \mathrm{~m}^{2}$ was classified as S. spinulosa reef. ${ }^{100}$ Eight other locations (four in Dutch waters and four in UK waters) were observed in which S. spinulosa was present but did not form reefs, but instead occurred in isolated aggregations of tubes. In one such location in Dutch waters, these clusters of S. spinulosa tubes formed a dense field of aggregations (Figure 11).

Among the most common organisms documented in association with the reefs were crustaceans, specifically crabs. Long-clawed porcelain crab (Pisidia longicornis) was very highly abundant amongst the $S$. spinulosa tubes of two reefs, but its abundance could not be easily quantified due to its small size. This crevice-dwelling species is known to be extremely abundant on $S$. spinulosa reefs elsewhere in the southern North Sea. ${ }^{101}$ Swimming crabs (Liocarcinus sp.) were also very commonly observed, with dozens of individuals seen on each of the reefs, while edible crab (Cancer pagurus) and velvet swimming crab (Necora puber), were less abundant but still frequently documented. Common sea star (Asterias rubens) was very abundant on all three reefs, with hundreds of individuals observed along the transects.

Fishes observed in association with the reefs included common dragonet (Callionymus lyra) and lesser spotted dogfish (Scyliorhinus canicula). Common dragonet has been observed to feed predominantly on long-clawed porcelain crab (P. longicornis). ${ }^{102}$ In the case of lesser spotted dogfish, 17 individuals were unexpectedly observed resting among the Sabellaria tubes. This species is the most common elasmobranch in the North Sea, but the Sabellaria reefs of Brown Bank represented the only area of the North Sea in which it was documented during the 2017 and 2018 Oceana 
North Sea expeditions. Its high abundance in the area of the reefs may have been linked to the relatively high biomass and avail-

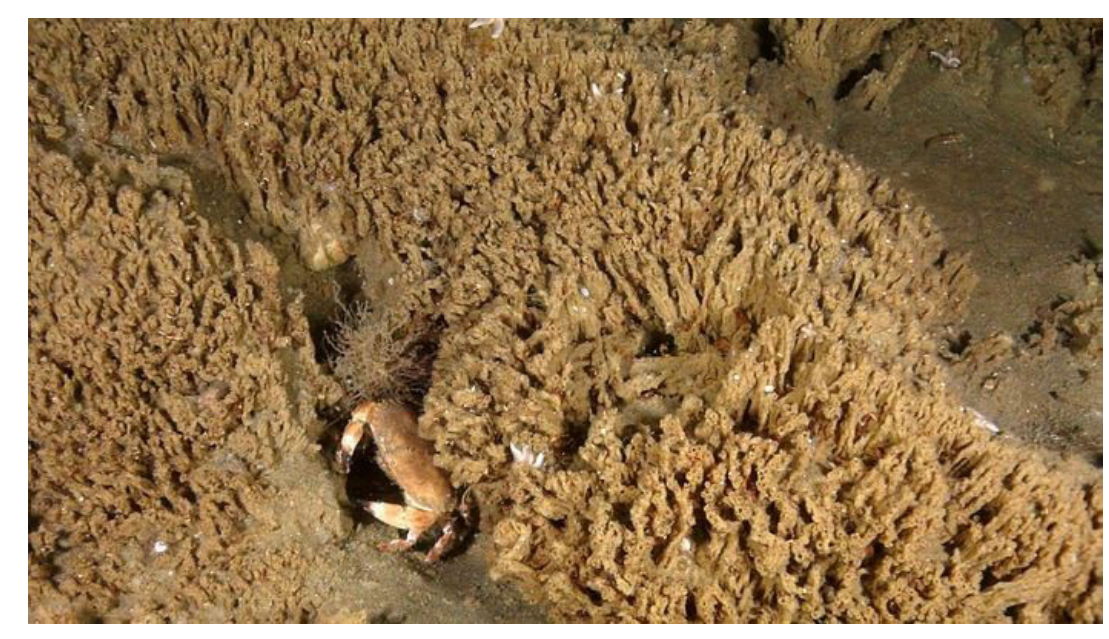
ability of prey in this habitat. Lesser spotted dogfish feed on a variety of species that were abundant in the area, including molluscs, crustaceans, and small fish. ${ }^{103}$

The occurrence of S. spinulosa reefs in Brown Bank appeared to coincide with a set of specific physical factors. The three reefs were observed on the lower part of the bank slope or

Figure 10. Edible crab (Cancer pagurus) in a Sabellaria spinulosa reef in Dutch waters of Brown Bank. tween $38 \mathrm{~m}$ and $45 \mathrm{~m}$. In addition, the reefs were observed to occur in the troughs between sand ripples. Few $S$. spinulosa tubes were observed on the surface of the ripples. In UK waters further west of Brown Bank, S. spinulosa have also been observed in association with depressions among sand ripples. ${ }^{104}$ This association suggests that the troughs serve as suitable habitat for Sabellaria settlement and may provide some degree of refuge from the intensive bottom fisheries in the area. ${ }^{100}$

\section{ARTIFICIAL SUBSTRATA \\ (WRECKS) COVERED BY INVERTEBRATES}

[EUNIS code: A4: Circalittoral rock and other hard substrata]
Figure 11. Field of Sabellaria spinulosa tube aggregations, discovered in Dutch waters of Brown Bank.
Two wrecks were surveyed in Brown Bank, the MFV Wisselvalligheid and MV Elatma, ${ }^{105}$ both lying on detritic sandy bottom. The wrecks were covered by various sessile species, mainly cnidarians and sponges, and hosted schools of fishes and other mobile species, such as crustaceans (e.g., edible crab (Cancer pagurus) and velvet swimming crab (Necora puber)).

The first wreck, MFV Wisselvalligheid, a $40 \mathrm{~m}$ long Dutch steel bottom trawler, which sunk in 1996, was found at $43 \mathrm{~m}$ depth and rose roughly $8 \mathrm{~m}$ from the bottom. The wreck was almost completely covered by sea anemone species Actinothoe sphyrodeta and Metridium dianthus (Figure 12), together with the hy- 
drozoan Tubularia indivisa and sponges as Anthos sp. Schools of pollack (Pollachius pollachius), horse mackerel (Trachurus trachurus) and bib (Trisopterus luscus) were abundant around the wreck.

The second wreck, the MV Elat$\mathrm{ma}$, is a $103.6 \mathrm{~m}$ long Russian steel cargo ship that sank in 1994. It was found at $39.1 \mathrm{~m}$ depth and rose around $8 \mathrm{~m}$ from the bottom. The wreck was mainly covered by $T$. indivisa, but also had some surfaces with the sea anemones $A$. sphyrodeta and $M$. dianthus. On this wreck, juvenile Asterias rubens were also found, forming facies covering some parts of the wreck (Figure 13). Schools of bib (T. luscus) were also present.

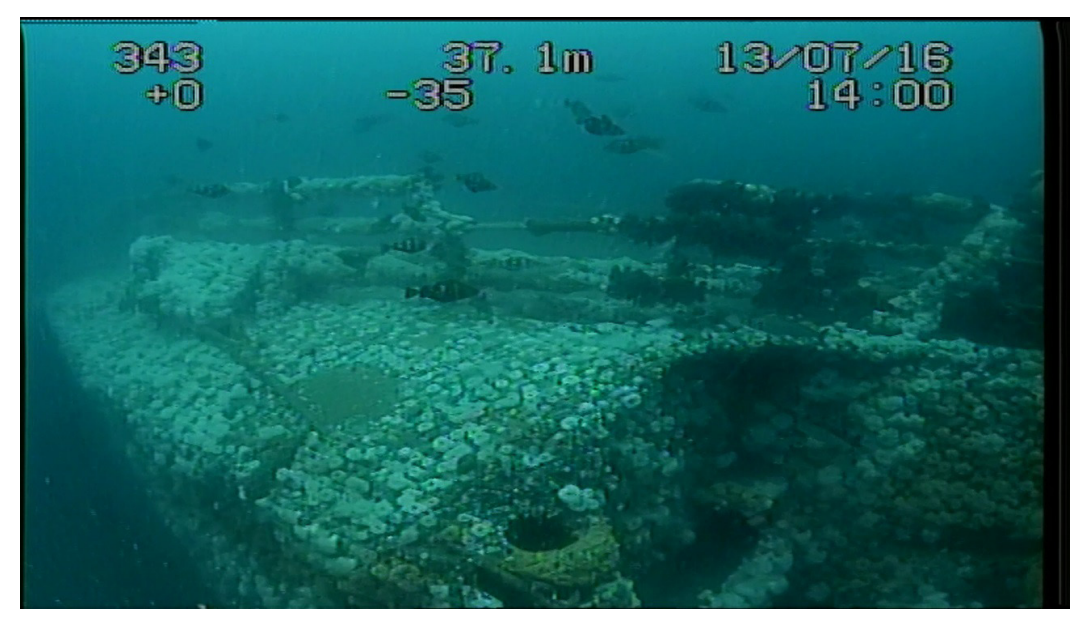
luscus.

FeATURES OF CONSERVATION INTEREST

The two Oceana expeditions documented a variety of species and habitats in Brown Bank that are considered priorities for conservation, because these features are included within national, European, or regional frameworks that recognise their threatened status, and/or establish requirements for their legal protection (Table 2). These include: Red Lists of threatened species; UK 'Features of Conservation Interest' (FOCI) for the designation of Marine Conservation Zones; the UK Biodiversity Action Plan; EU directives (i.e., the Habitats Directive and the Marine Strategy Framework

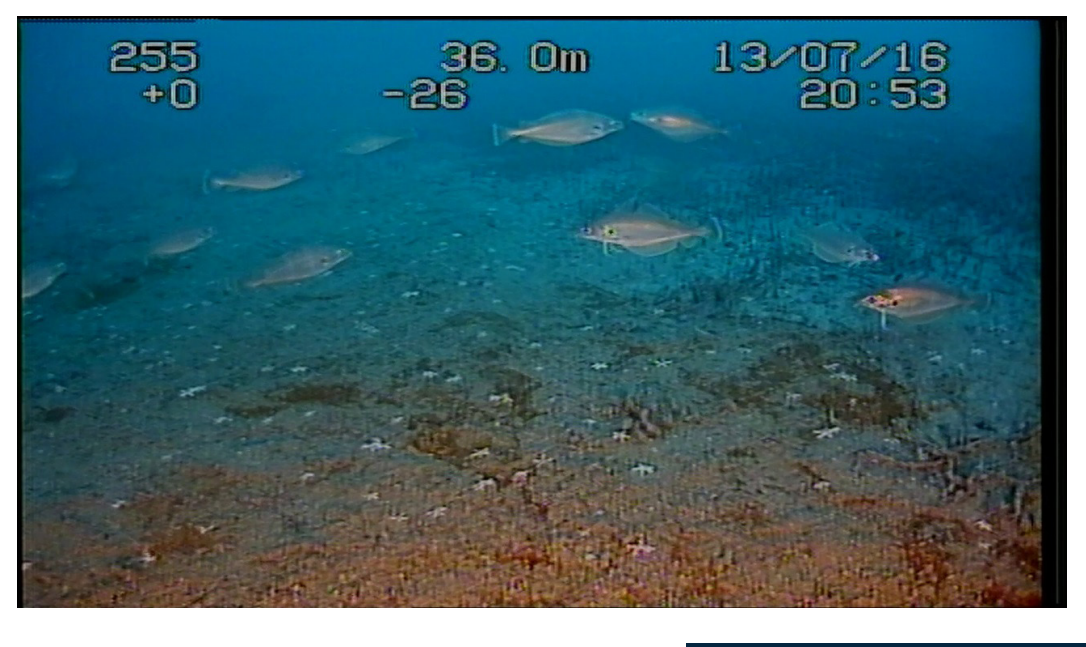
Directive); and the OSPAR Commission. As such, their occurrence in Brown Bank area deserves special consideration, with respect to the biodiversity value of the area and required management measures.

Figure 13. Part of the MV Elatma covered by sediment, Tubularia indivisa, Asterias rubens, and Trisopterus luscus. 


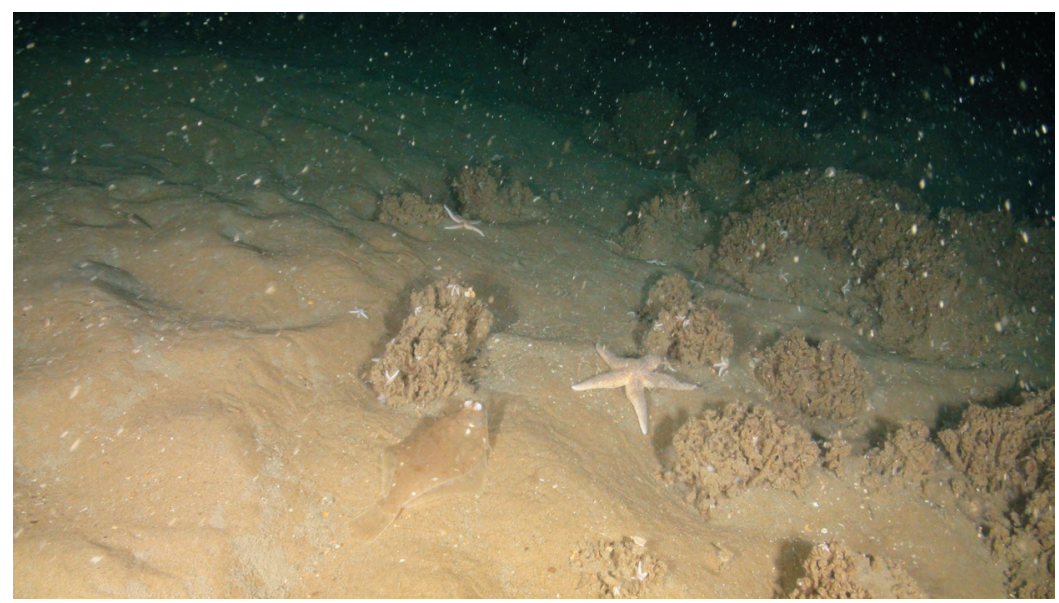

Ross worm (S. spinulosa) reefs were the feature documented in Brown Bank that are of the greatest conservation interest. Although historical accounts suggest that such reefs had previously occurred in Dutch waters, ${ }^{106}$ the findings of the Oceana expeditions have revealed the presence of reefs in at least three locations in Brown Bank (Figure 7). Their occurrence is particularly noteworthy giv-

Limanda limanda and Sabellaria spinulosa en that biogenic reefs in general have almost disappeared from Dutch waters.

The importance of reefs formed by these tube-building polychaete worms has been well recognised, as they increase the habitat complexity of soft bottoms and have been defined as biodiversity hotspots due to their associated species richness. ${ }^{107,108}$ The conservation value of $S$. spinulosa reef habitats is highest where they occur in areas of sediment or mixed sediment bottoms, such as Brown Bank; they provide a biogenic habitat that rises above the seabed, thereby permitting the settlement of epibenthic and infaunal species not found in adjacent habitats. ${ }^{109,110}$

Given their ecological importance, the protection of S. spinulosa reefs is included within major EU conservation legislation such as the Habitats Directive, ${ }^{87}$ which covers biogenic concretions under the 'Reefs' habitat type of community interest (1170), and specifically mentions $S$. spinulosa as a reef-forming species in the North Sea. ${ }^{111}$ Polychaete worms are also listed under the description of the habitat 'Sandbanks which are slightly covered by sea water all the time' (1110), as characteristic fauna associated with this habitat. In the EU Marine Strategy Framework Directive (MSFD), Sabellaria reefs qualify for inclusion under the two qualitative descriptors that are relevant for benthic habitats (D1: Biodiversity and D6: Sea-floor integrity) and are considered a 'special habitat type. ${ }^{112}$ In the case of the Netherlands, one environmental target under the MSFD relates specifically to the "return and recovery of biogenic reefs." 113 OSPAR also includes these reefs on its List of Threatened and/or Declining Species and Habitats, and establishes recommended measures for Sabellaria protection, such as limiting certain fisheries and aggregate extraction practices. ${ }^{114}$ 
In contrast to Dutch waters, no Sabellaria reefs were documented during Oceana surveys in UK waters of Brown Bank; only isolated tube aggregations were found. However, it should be noted that the sampling effort on the UK side of Brown Bank was lower than in Dutch waters. Due to the relatively close proximity to the Dutch reefs, the substrate homogeneity, and the documented presence of aggregations, the possibility remains that Sabellaria reefs could also be present in the UK portion of Brown Bank.

\section{Sandbanks}

The conservation of sandbanks such as Brown Bank is a priority because of the range of ecosystem goods and services that these systems provide. They support diverse communities of epifauna and infauna (particularly in areas between banks), they serve as feeding and nursery grounds for some commercial fishes, and they act to dissipate wave energy, thereby reducing coastal erosion. ${ }^{115,116}$ Sandbanks fall under the Natura 2000 habitat type of community interest 1110: Sandbanks which are slightly covered by water all the time. This habitat type is relatively broad, comprising systems with a variety of substrate characteristics and depths. Under this definition, the water depth above a sandbank is not typically more than $20 \mathrm{~m}$, while the sides of sandbanks can extend below this depth. ${ }^{111}$ In the Netherlands, this category is interpreted as encompassing the entire complex of sandbanks, troughs and channels between them; any hard structures; and the water column that lies above all of these features. ${ }^{117}$ In the UK, it is taken to include the distinct banks (whether elon-

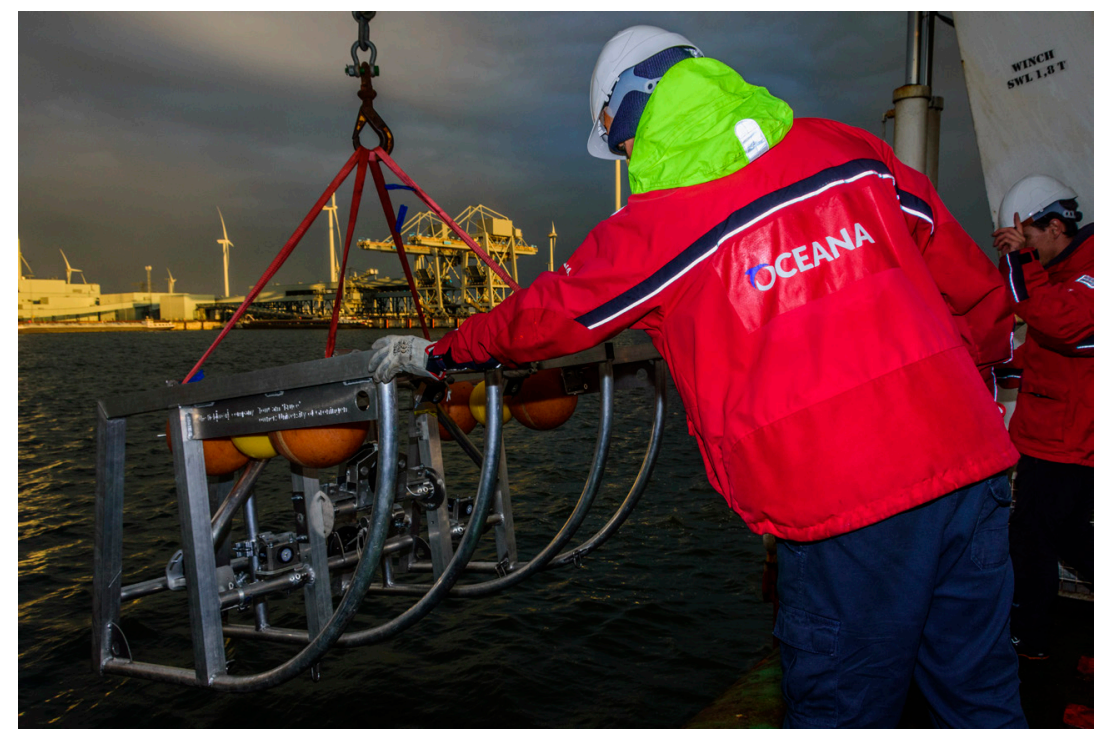
gated, rounded, or irregular in shape), the flanks of sandbanks, and may also include channels or other areas that are closely 
Figure 14. Ostrea edulis found on sandy bottom, in UK waters of Brown Bank. associated with the banks, in order to maintain the structure and functions of the system. ${ }^{118}$ According to reports on the conservation status of habitats and species listed under the Habitats Directive, the quality of sandbank habitats in both the Netherlands and UK is deteriorating, ${ }^{119,120}$ suggesting that current protection measures are insufficient. In the Netherlands, more than $60 \%$ of this habitat type falls within Natura 2000 areas, in line with EU recommendations. ${ }^{121}$ However, for many of these areas, no measures have been implemented yet. Beyond the Habitats Directive, sandbanks in both Dutch and UK waters are also included broadly under various targets associated with the two MSFD descriptors related to benthic habitats (D1 and D6), which include measures related to the reduction of human impacts on the seabed.

\section{THREATENED AND PROTECTED SPECIES}

Nine species identified in Brown Bank during the Oceana North Sea expeditions are considered priorities for conservation, based on their inclusion in relevant conservation frameworks (Table 2). These species include one bivalve, six fishes, and two cetaceans. Figure 15 shows the locations where these species were observed.

\section{Ostrea edulis}

Four individuals (all dead) of European flat oyster (Ostrea edulis) were documented from two locations in UK waters of Brown Bank (Figure 14). This species was once abundant and widely distributed in the North Sea - including in large offshore areas of the southern North Sea. ${ }^{122}$ In the mid- $19^{\text {th }}$ century, its populations began to decline dramatically, primarily as a result of overexploitation; by the 1950s, flat oyster beds had become scarce. ${ }^{123}$ The loss of such beds across many parts of their former range has meant the loss of associated ecosystem services in those areas, including the provision of hard substrate, habitat, and food for other species; water filtration; sediment stabilisation; and fisheries. ${ }^{124}$ The species remains the focus of conservation and restoration efforts in both the Neth- 
erlands and the UK, and both countries, as contracting parties to OSPAR, are required to protect and restore flat oysters and flat oyster beds. ${ }^{125}$

\section{Fishes}

Oceana surveys documented six fish species that are listed under either international and/or national conservation frameworks. Of these fishes, five are commercially captured: cod (Gadus morhua), plaice (Pleuronectes platessa), thornback ray (Raja clavata), sole (Solea solea) and greater weever (Trachinus draco).

Cod is considered to be over-

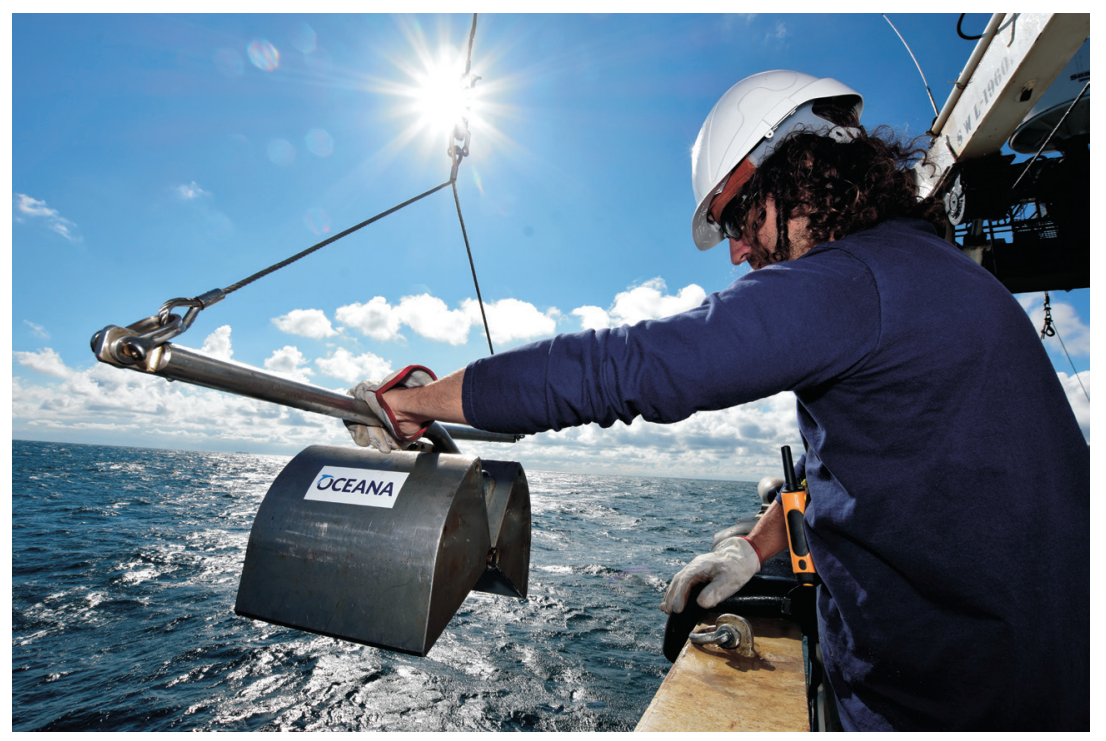
exploited in the North Sea, following significant population declines since the $1970 \mathrm{~s},{ }^{126}$ and is listed under OSPAR. Although some cod sub-populations in the North Sea appear to have been gradually recovering since the mid-2000s, cod in the southern North Sea (including Brown Bank) has continued to decline. ${ }^{126}$

Plaice and sole are both listed as priority species under the UK Biodiversity Action Plan. ${ }^{127}$ As previously mentioned, they are the two main targets of the intensive beam trawl fisheries in the Brown Bank area. The North Sea plaice population was fished down to critical levels because of overfishing in the 1970 s and 1980 s, ${ }^{128}$ but spawning stock biomass has since increased in response to reduced fishing pressure, and the stock is currently considered to be fished at sustainable levels. ${ }^{129}$ Sole similarly declined due to unsustainable fishing pressure in the $1970 \mathrm{~s}$ and 1980 s, ${ }^{130}$ but following a reduction in fishing pressure, the North Sea population has gradually increased in recent years. Nevertheless, the latest ICES assessment has shown that current fishing levels are still too high to be sustainable. ${ }^{131}$

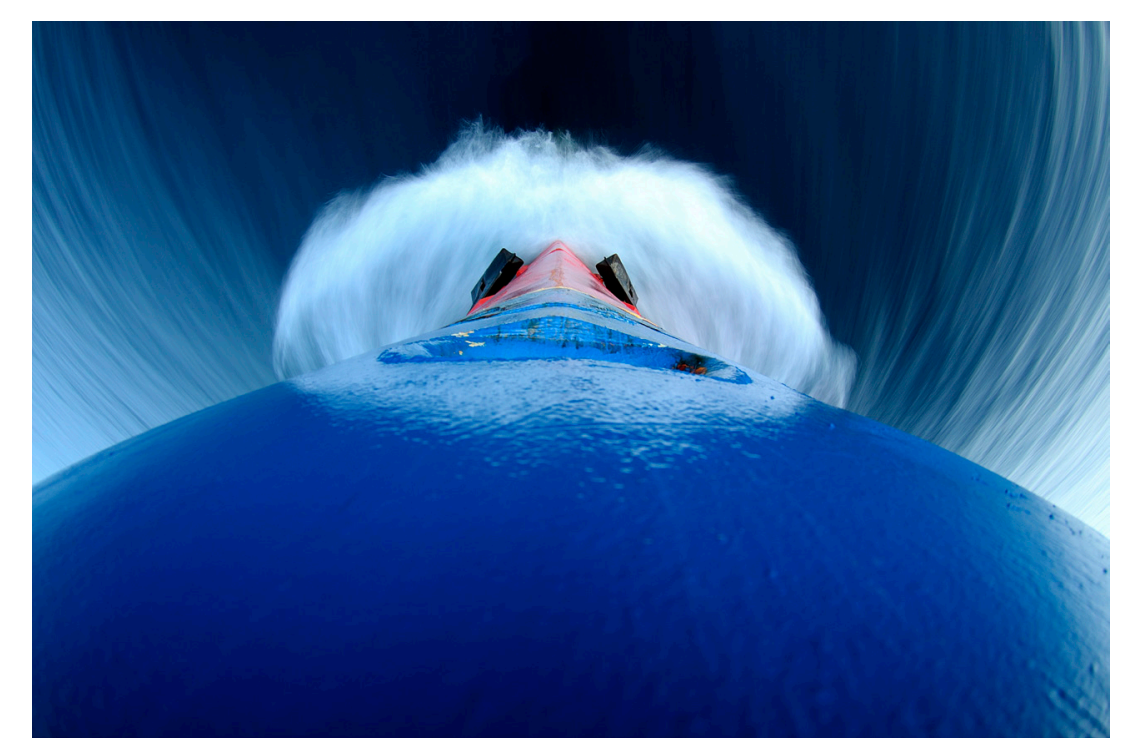


The observation of thornback ray in Brown Bank is also of conservation interest. During the past century, larger skates and rays such as the common skate complex and the thornback ray have disappeared either completely or from large parts of their previous distributional ranges in the southwestern North Sea. ${ }^{132,133}$ In recent years, however, a moderate population increase has been observed in the thornback ray population in those waters, along with increasing rates of discards of this species in fisheries. ${ }^{134}$ The Dutch government, in its 2018 update of good environmental status (GES) under the MSFD, has highlighted the poor conservation status of skates and rays, and the need for mitigating measures to reduce undesired bycatch. ${ }^{113}$

Finally, greater weever (Trachinus draco) was observed in Dutch waters of Brown Bank. This species is listed as Critically Endan-

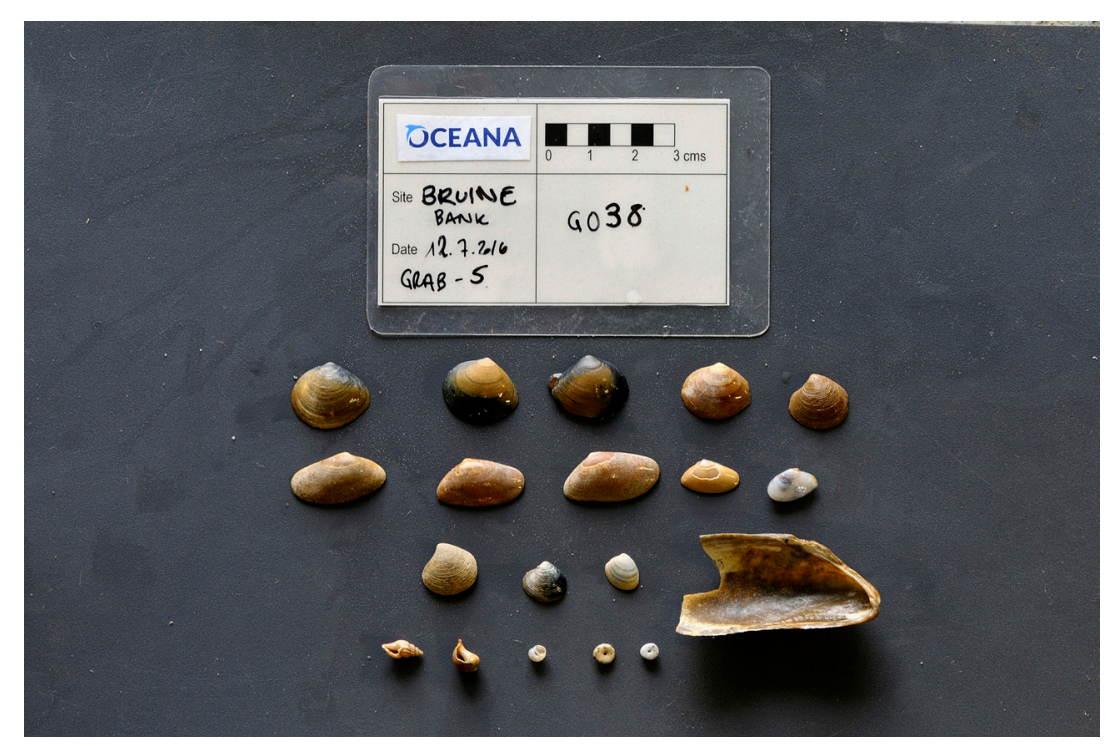
gered on the Netherlands Red List of Fishes, on the basis of an extreme decline since the 1950s, the effects of which were later compounded by heavy benthic fishing pressure in the area. ${ }^{135}$

\section{Cetaceans}

Two species of cetaceans were documented during the surveys. A dead minke whale ( $\mathrm{Ba}-$ laenoptera acutorostrata) was spotted in Dutch waters of Brown Bank. Although minke whale is a resident species in

Specimens from a grab sample (c) OCEANA/Juan Cuetos the North Sea, ${ }^{136}$ it is found mainly in the northern and central areas and is rare in the southern half of the North Sea. ${ }^{137}$ The fact that the specimen was found dead and in an advanced state of decomposition suggests that it could have drifted to Brown Bank from more northerly areas. Also recorded were two small cetaceans, possibly harbour porpoises (Phocoena phocoena), on the Dutch side of Brown Bank, but they were not identified to species level. Cetaceans in the North Sea face a wide range of threats, including incidental catches in fisheries, overfishing of main prey species, the bioaccumulation of pollutants, and underwater noise disturbance. ${ }^{138}$ As such, all cetaceans are listed as strictly protected under Annex IV of the Habitats Directive. 



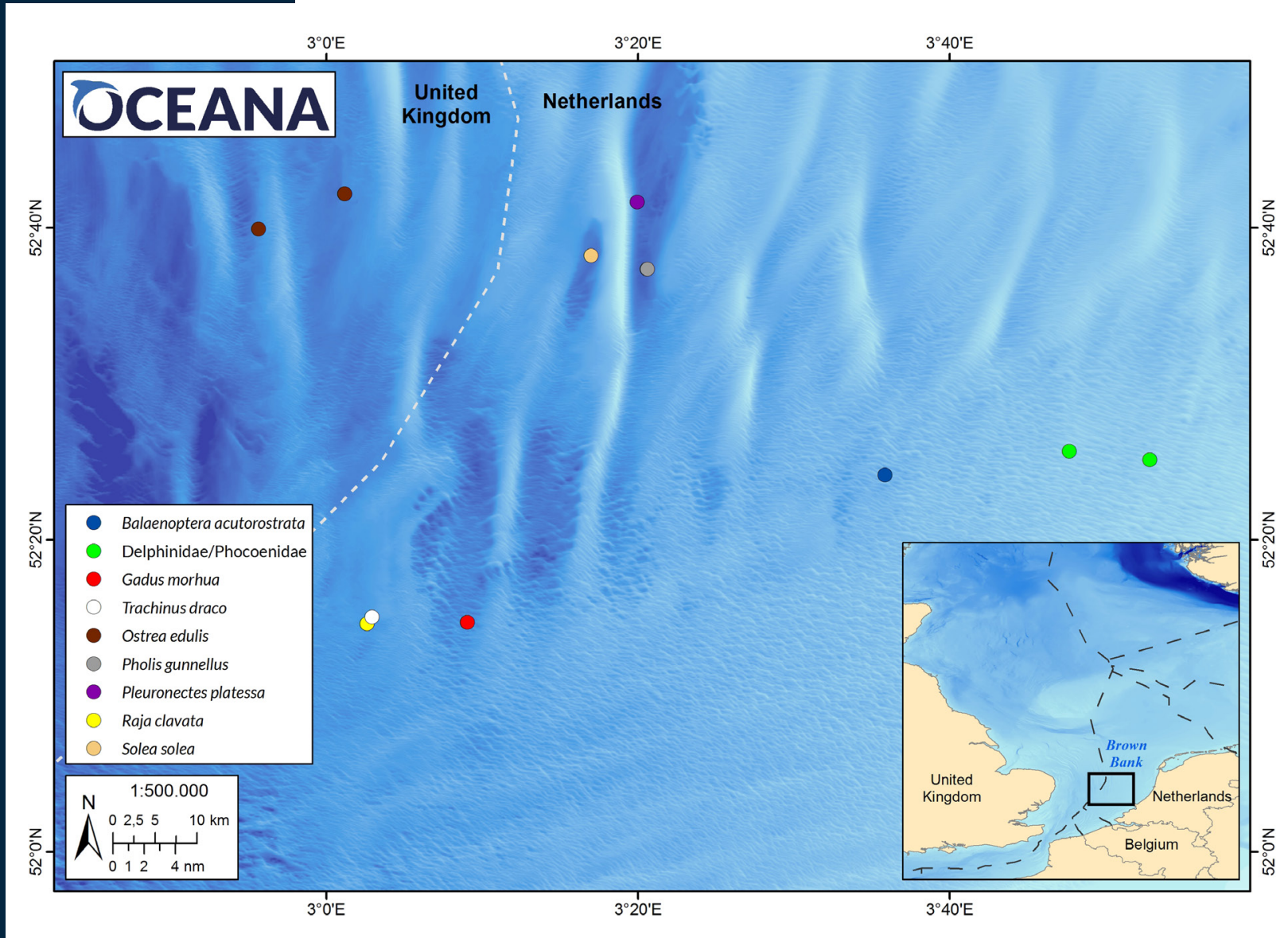

Figure 15. Protected and threatened species observed in Brown Bank during the 2016 and 2017 Oceana expeditions.

Among the organisms recorded during Oceana surveys of Brown Bank were a wide range of species that are commercially fished in the southern North Sea, including fishes, crustaceans, and molluscs (Table 3). These species include fishes for which Brown Bank is known to represent essential fish habitat (EFH; see Known ecological features of interest), including sandeels (Ammodytes spp.), cod (Gadus morhua), plaice (Pleuronectes platessa), and sprat (Sprattus sprattus). For example, the lesser sand eel (Ammodytes tobianus) was found in four of the 14 grab samples, which adds to previous research that has shown that the species is common in Brown Bank and also spawns in the area. ${ }^{26}$ 
Table 3. Commercial species observed during Oceana surveys of Brown Bank. Species were identified as commercially fished based on reported catches from the southern North Sea (FAO Division 27.4c), according to Eurostat records from 2008-2017. 140

\begin{tabular}{|c|c|}
\hline Species & Common name \\
\hline \multicolumn{2}{|l|}{ ARTHROPODA } \\
\hline Brachyura indet. & Crab \\
\hline Cancer pagurus & Edible crab \\
\hline Carcinus maenas & Shore crab \\
\hline Necora puber & Velvet swimming crab \\
\hline \multicolumn{2}{|l|}{ CHORDATA } \\
\hline Agonus cataphractus & Pogge \\
\hline Ammodytes spp. & Sand eels \\
\hline Callionymus lyra & Common dragonet \\
\hline Eutrigla gurnardus & Grey gurnard \\
\hline Gadus morhua & Cod \\
\hline Hippoglossoides platessoides & Long rough dab \\
\hline Limanda limanda & Dab \\
\hline Micromesistius poutassou & Blue whiting \\
\hline Mullus surmuletus & Striped red mullet \\
\hline Platichthys flesus & European flounder \\
\hline Pleuronectes platessa & Plaice \\
\hline Pleuronectidae indet. & Righteye flounder \\
\hline Pollachius pollachius & Pollack \\
\hline Raja clavata & Thornback ray \\
\hline Scyliorhinus canicula & Lesser spotted dogfish \\
\hline Soleidae indet. & Sole \\
\hline Sprattus sprattus & European sprat \\
\hline Trachinus draco & Greater weever \\
\hline Trachurus trachurus & Horse mackerel \\
\hline Trisopterus esmarkii & Norway pout \\
\hline Trisopterus luscus & $\mathrm{Bib}$ \\
\hline \multicolumn{2}{|l|}{ MOLLUSCA } \\
\hline Cerastoderma edule & Edible cockle \\
\hline Littorina littorea & Periwinkle \\
\hline Ostrea edulis & European flat oyster \\
\hline
\end{tabular}




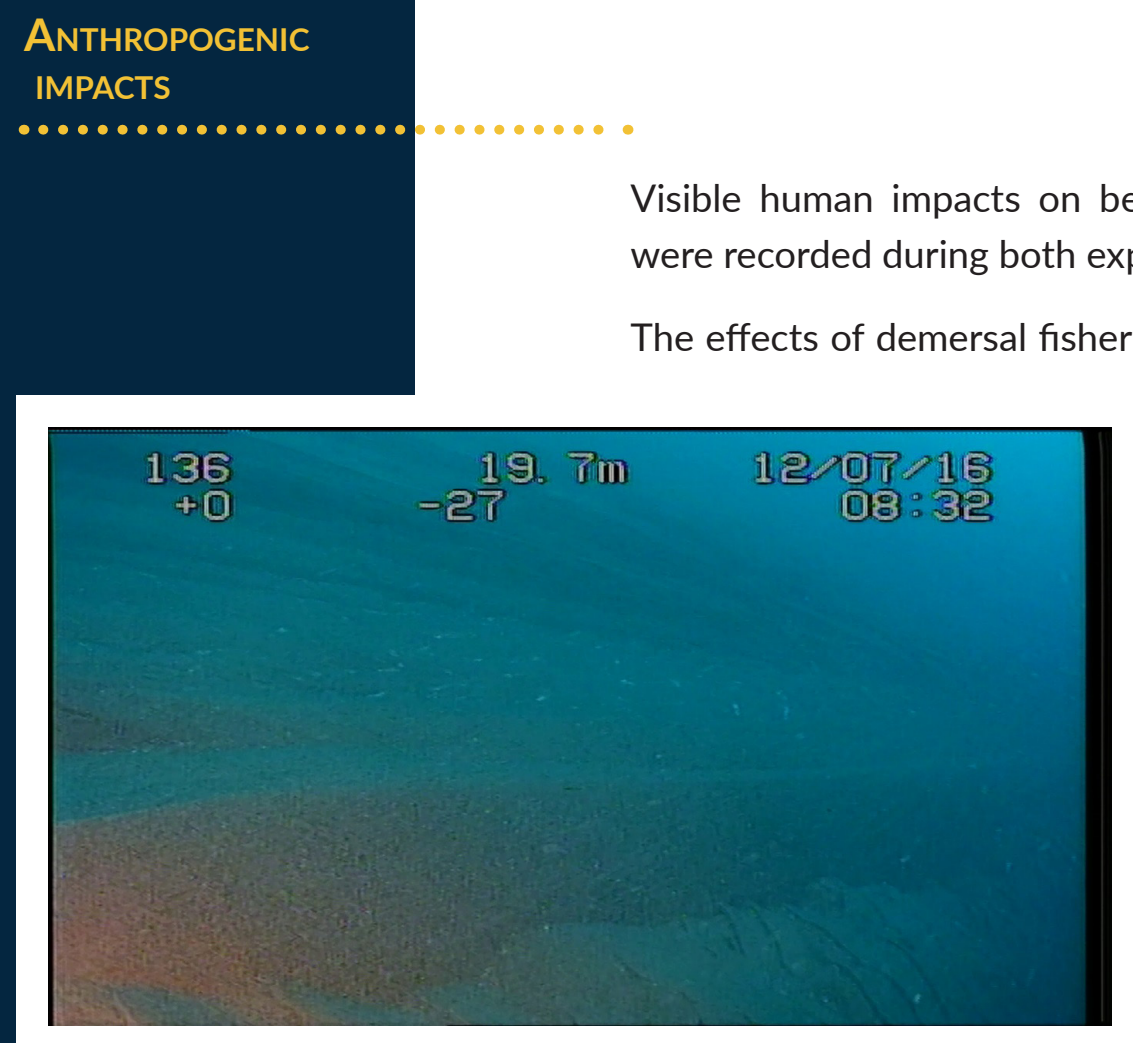

Visible human impacts on benthic ecosystems in Brown Bank expeditions.

he effects of demersal fisheries, the main human activity in the area, were clearly visible during ROV dives. The seabed was noticeably altered in some sites, due to physical impacts by demersal fishing gear (Figure 16). These impacts have been categorised as geotechnical (i.e., physical penetration in the sea bottom) and hydrodynamic (i.e., generation of turbulence and mobilisation of sediments) $)^{141}$ and produce, if used intensively, deleterious biochemical and

Figure 16. Trawl mark on the seabed in Brown Bank.

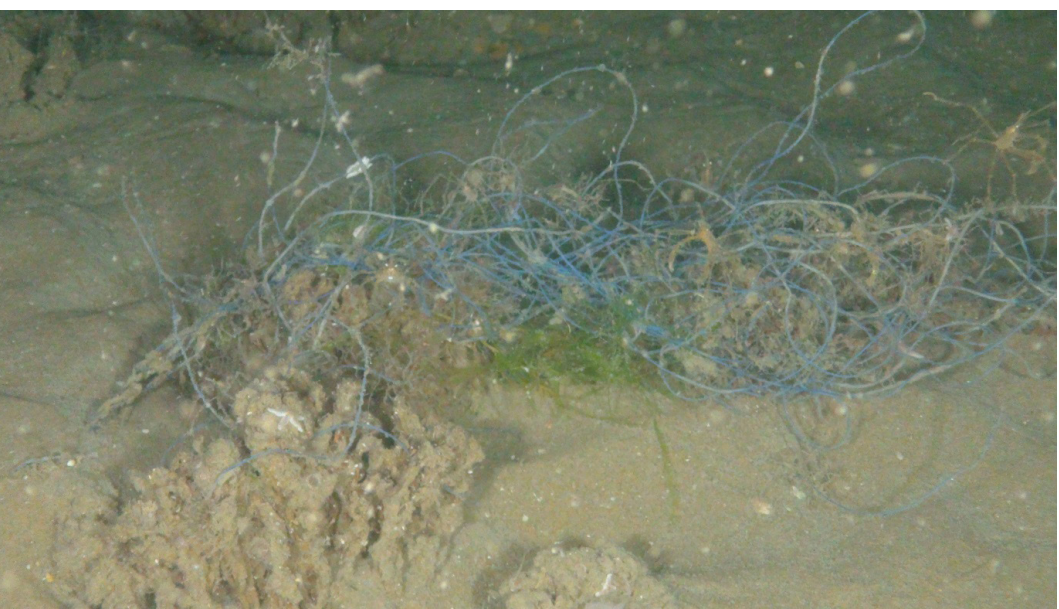

biological effects that can seriously reduce infaunal and meiofaunal biodiversity and ecosystem functioning. ${ }^{142,143}$ These effects include significant decreases in organic matter content, slower organic carbon turnover, and reduction of meiofaunal abundance and biodiversity, among others. ${ }^{142}$ Wherever there are biogenic reefs - known to be biodiversity hotspots - on the seabed, the effects of demersal fisheries can be much more severe. ${ }^{57}$

In addition to these impacts, marine litter was also documented in Brown Bank, during five of the 13 ROV dives. These records included plastic and metal litter, and lost fishing nets and lines, including fishing line that was directly entangled in a fragile $S$. spinulosa reef (Figure 17). 


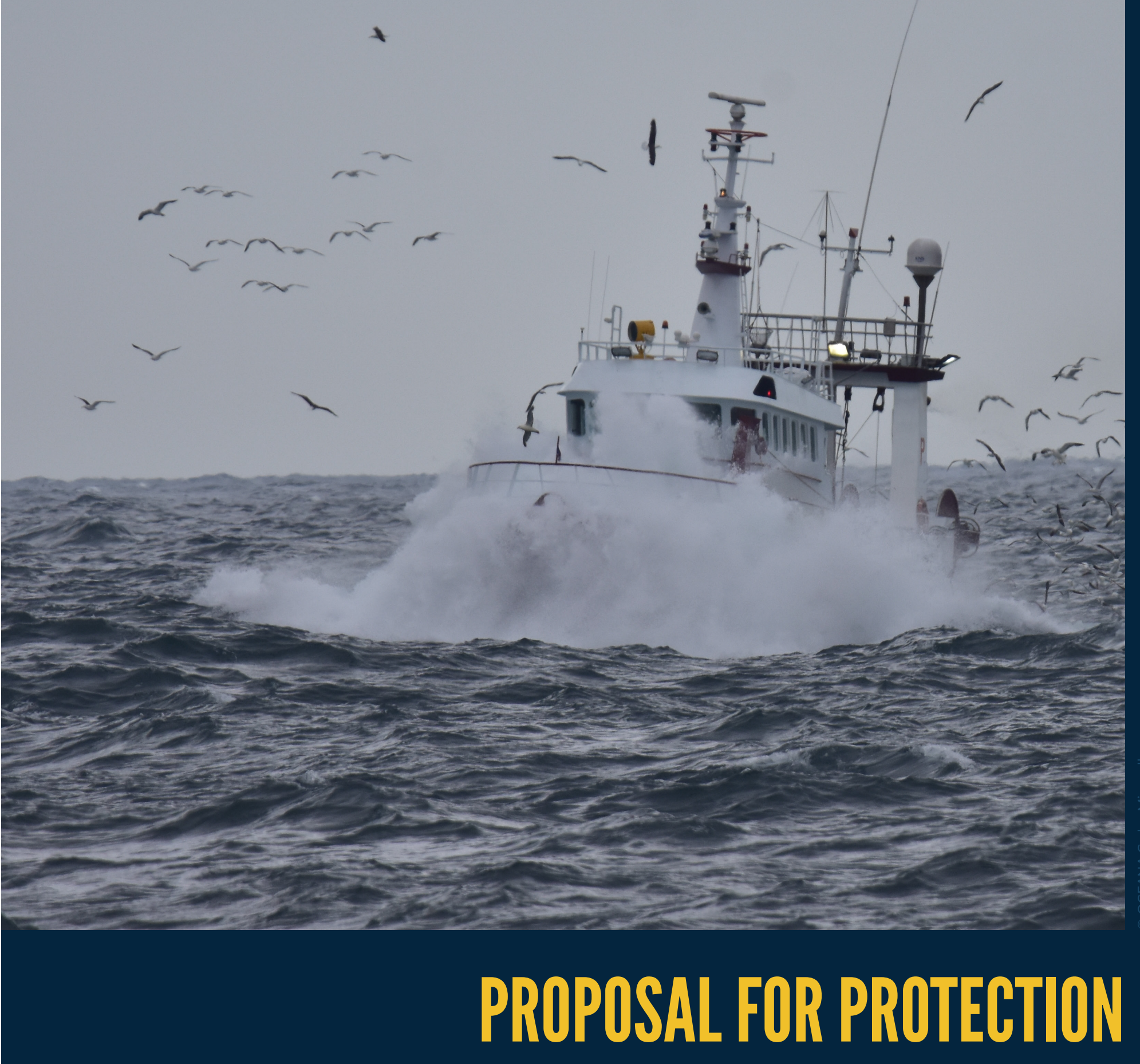


T he protection of Brown Bank has long been considered a priority (see Previous conservation proposals), and numerous scientific studies have highlighted the value of the area for seabirds and for marine mammals (see Known ecological features of interest). To date, only limited protection has been put in place; UK waters of Brown Bank are protected for a single species, harbour porpoise (Phocoena phocoena), within the Southern North Sea Natura 2000 area. Meanwhile, the government of the Netherlands has repeatedly delayed its decision on the designation of Brown Bank as an MPA under the Birds Directive, even though the area meets the necessary requirements (see Previous conservation proposals).

The findings of Oceana's two research expeditions to Brown Bank add significantly to knowledge about the biodiversity value

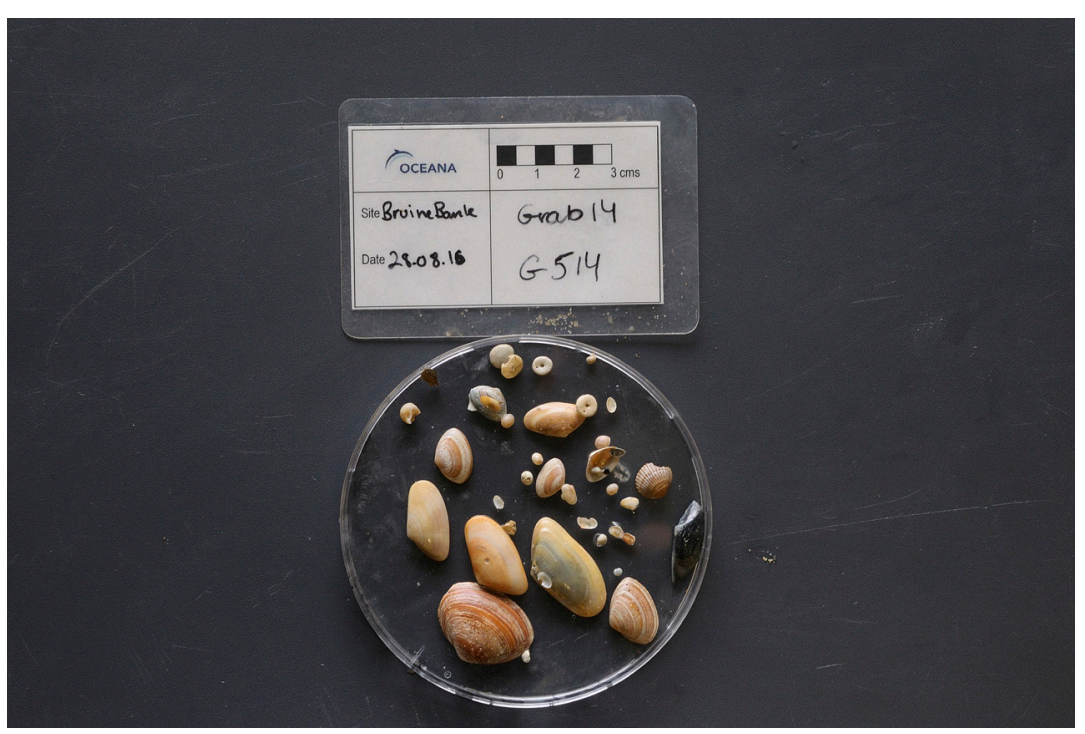
of the area, particularly with the discovery of ross worm (Sabellaria spinosa) reefs, which were thought to have been long-extinct in Dutch waters. While official Dutch documents had suggested that Brown Bank did not meet criteria for the protection of benthic habitats or fauna, ${ }^{46,88}$ these statements reflected the fact that the area had not been sufficiently studied to fully assess the value of the benthos. Previous studies were based on relatively limited sampling

methods, using primarily box-corers and or dredges (see Previous research surveys in the area), rather than the visual surveys that Oceana carried out using a remotely operated vehicle, which were informed by additional data about the seabed. These surveys revealed the presence of three separate $S$. spinulosa reefs in Dutch waters, and eight additional locations (in Dutch and UK waters) where aggregations of $S$. spinulosa tubes were found.

On the basis of this important discovery, Oceana recommends that Dutch waters of Brown Bank should be protected immediately, in order to safeguard the fragile $S$. spinulosa reefs. Biogenic reefs have all but disappeared from Dutch waters, and their protection is a recognised priority of the government of the Netherlands under the MSFD ${ }^{113}$ (see Features of conservation interest). Furthermore, as a Contracting Party to the OSPAR Convention, the Netherlands should take measures for the protection and recovery of S. spinulosa reefs, including measures to address and 
minimise adverse impacts upon them resulting from human activities, and the designation of MPAs for their conservation and recovery. ${ }^{144}$ Although the Netherlands is currently considered to have protected a sufficient area of 'reefs' and 'sandbanks' under the Habitats Directive, the rare and vulnerable S. spinulosa reefs are not known to occur in any other location on the Dutch continental shelf, and their conservation cannot be achieved via protection of reef structures or sandbanks elsewhere in the Dutch North Sea. Given this situation, the importance of Brown Bank in terms of representativity and coverage of $S$. spinulosa reefs is very high, in line with the criteria for its designation under the Habitats Directive. ${ }^{86}$ The still-pending decision on the protection of Brown Bank under the Birds Directive presents a clear opportunity for the Netherlands to designate the area as a $\mathrm{Na}$ tura 2000 MPA under both the Birds and Habitats Directives, recognising the high overall biodiversity value of the site.

Critically, the protection of Brown Bank must include minimising the impacts of anthropogenic pressure on the seabed. S. spinulosa reefs are often found in areas with relatively high levels of natural disturbance to the sediment, but at the same time they are particularly vulnerable to damage as a result of trawling or dredging. ${ }^{110}$ The area is intensively fished, predominantly through the use of beam trawls that
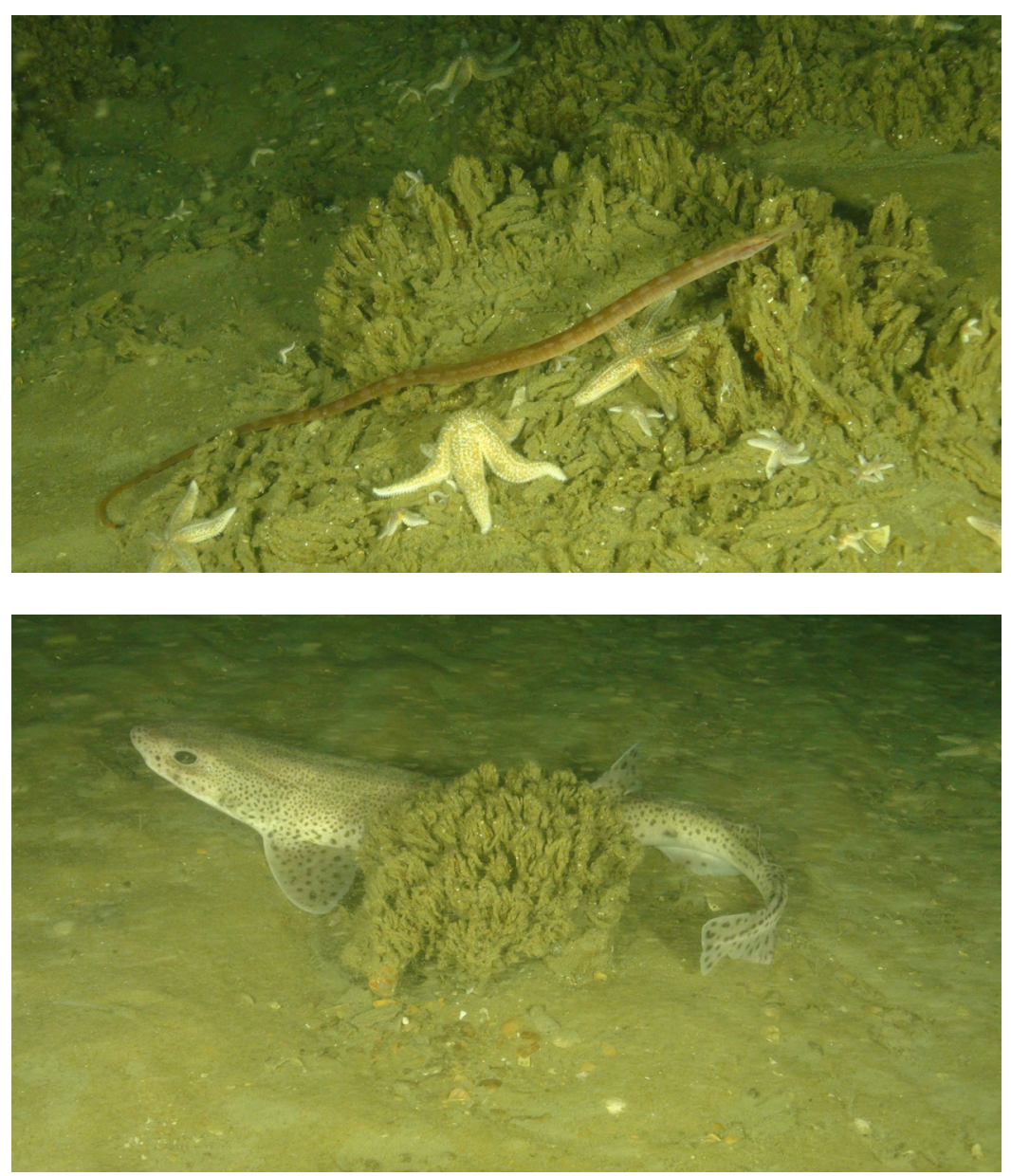
cause direct damage to biogenic reefs, ${ }^{44,57}$ and evidence from other locations (e.g., the Wadden Sea and Morecombe Bay) points towards cases where trawled S. spinulosa reefs have disappeared and not recovered. ${ }^{145}$ The $S$. spinulosa reefs in Brown Bank were primarily found in the valleys between small-scale sand waves, which appeared to provide refuge from the abrasive impacts of benthic fishing activities. ${ }^{100}$ In the absence of fishing pressure, it is possible that new reefs could develop in other sites where levels of demersal fishing pressure are currently prohibitive to their formation. In addition, the oc- 
currence of the reefs must be considered with respect to other potential threats. For example, the planned large-scale wind farm, IJmuiden Ver, overlaps with the area where the $S$. spinulosa reefs occur (Figure 18), raising serious concerns about the potential ad-

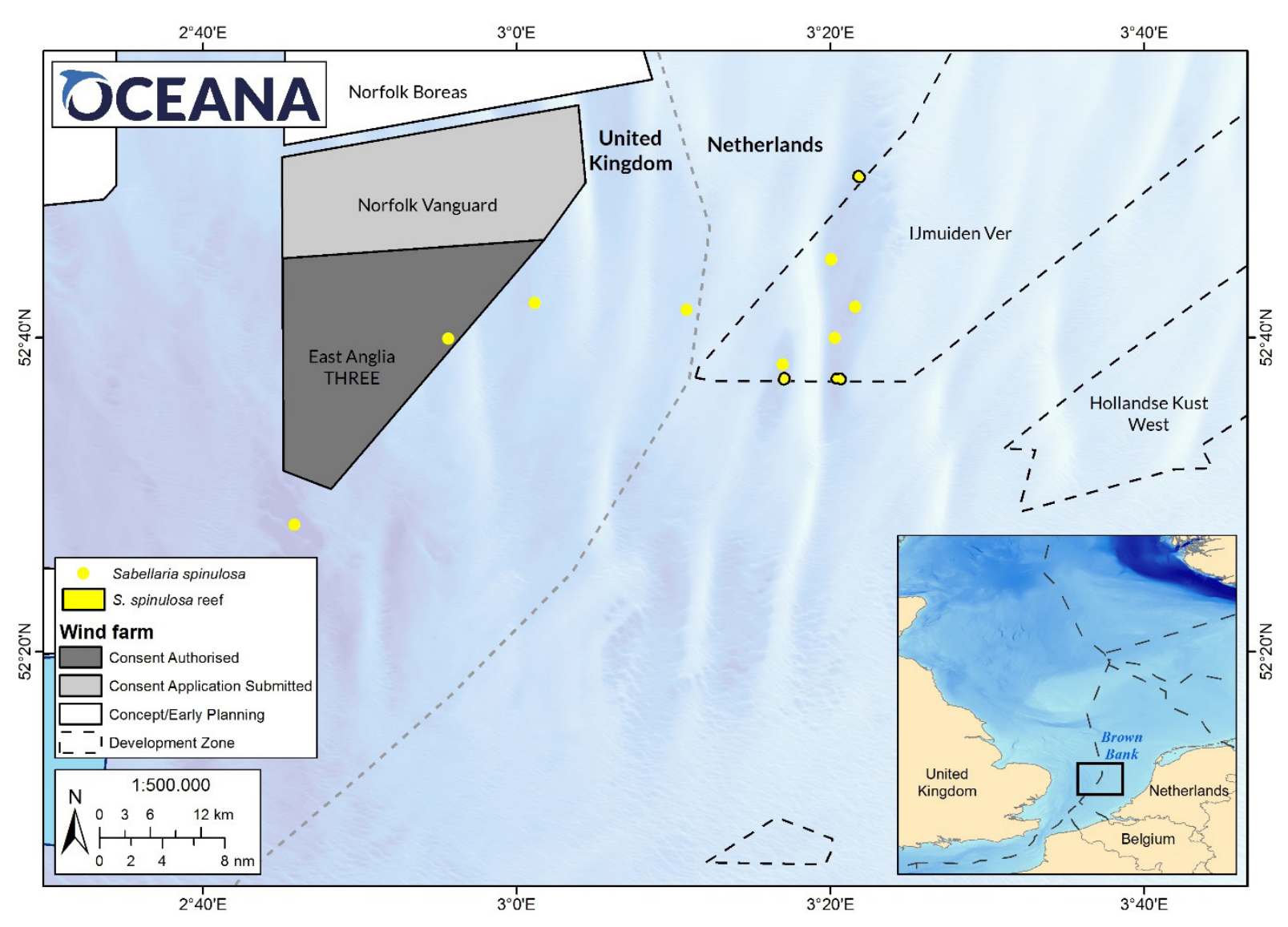

Figure 18. Locations of newly discovered Sabellaria spinulosa reefs, and other observations of $S$. spinulosa, in relation to planned wind farms in the Brown Bank area.

verse impacts of the wind farm and its associated infrastructure upon these fragile communities.

In parallel with protecting the newly discovered reefs, Oceana urges the governments of both the Netherlands and the UK to conduct comprehensive benthic habitat mapping of Brown Bank, to identify the presence of any additional $S$. spinulosa reefs and to assess their condition and extent. The three reefs that have been identified to date were discovered during exploratory ROV surveys that were not carried out with the aim of systematically mapping all of the benthic communities and habitats in the area. It is therefore likely that more such reefs exist in the vicinity of those that were identified during the Oceana surveys. ${ }^{100}$ The observed area where S. spinulosa was present was nearly three times larger than the area of the reefs themselves, suggesting both the potential occurrence of more reefs, and the possibility that more reefs could form in the area in the absence of threats. Although all of the observed reefs were documented from the Dutch side of Brown Bank, it should be 
noted that a much higher sampling effort was dedicated to Dutch waters. Given the homogeneity of the substrate across the area, and the fact that grab samples from UK waters contained aggregated tubes of S. spinulosa (Figure 19), it remains probable that reefs may also be present on the UK side of Brown Bank.

Conducting such research falls within the obligations of both the Netherlands and UK, as Contracting Parties to the OSPAR Convention. Seabed habitat surveys and monitoring are among the programmes and measures identified as priority actions for the protection and conservation of S. spinulosa reefs, in order to determine their distribution, extent and condition (mainly through non-destructive surveys), and to identify threats in their vicinity. ${ }^{144}$ The unexpected discovery of these biogenic reefs in Brown Bank makes it clear that benthic habitats and communities in the area have not been adequately studied, and that such surveys should be prioritised. Given the current heavy intensity of human activities in the area and the plans for future development of the area, it is imperative that the marine biodiversity of Brown Bank be properly assessed - and appropriately protected - before it is too late.

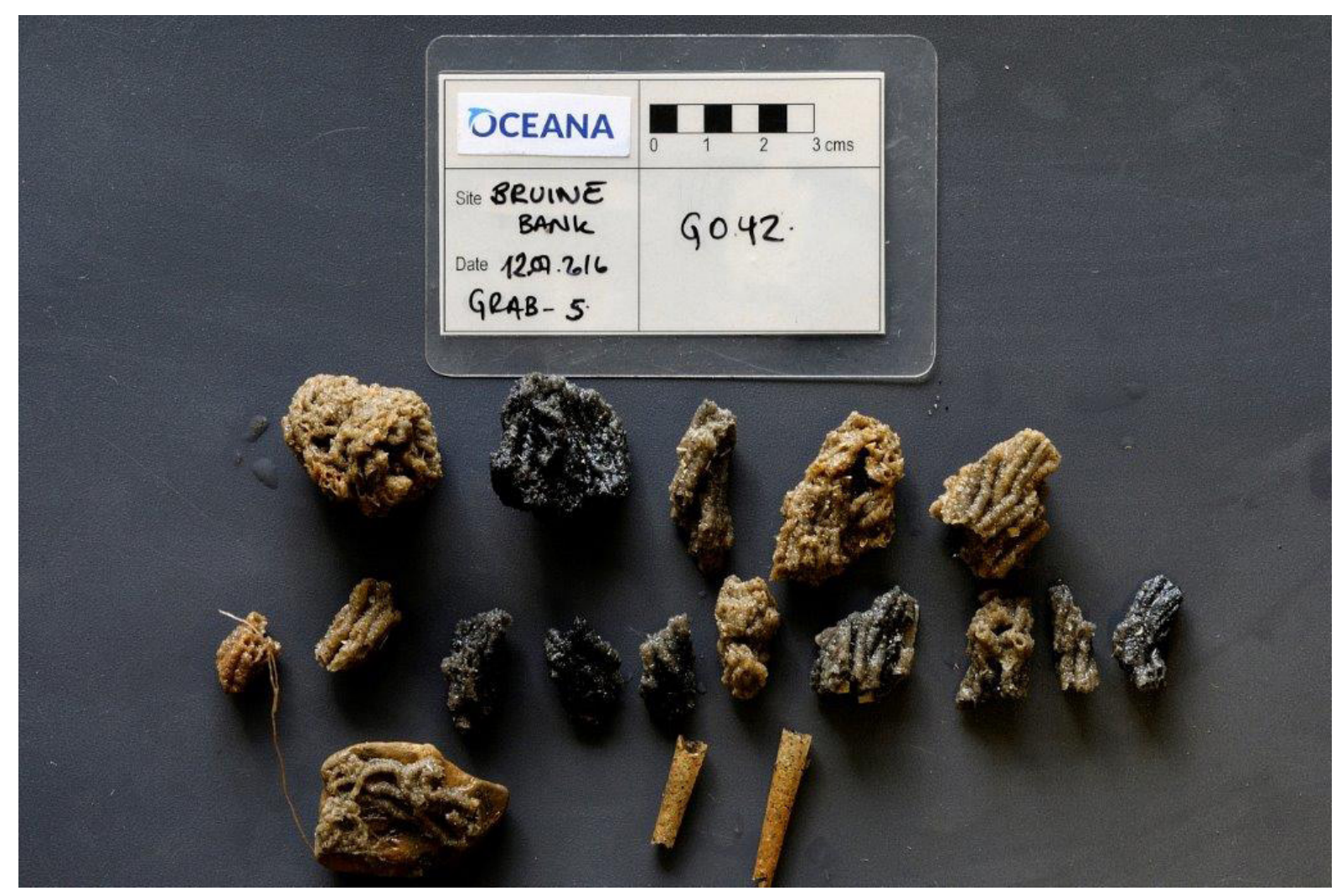

Figure 19. Aggregated tubes of Sabellaria spinulosa found in UK waters of Brown Bank, among other biological samples. (C) OCEANA/Juan Cuetos 


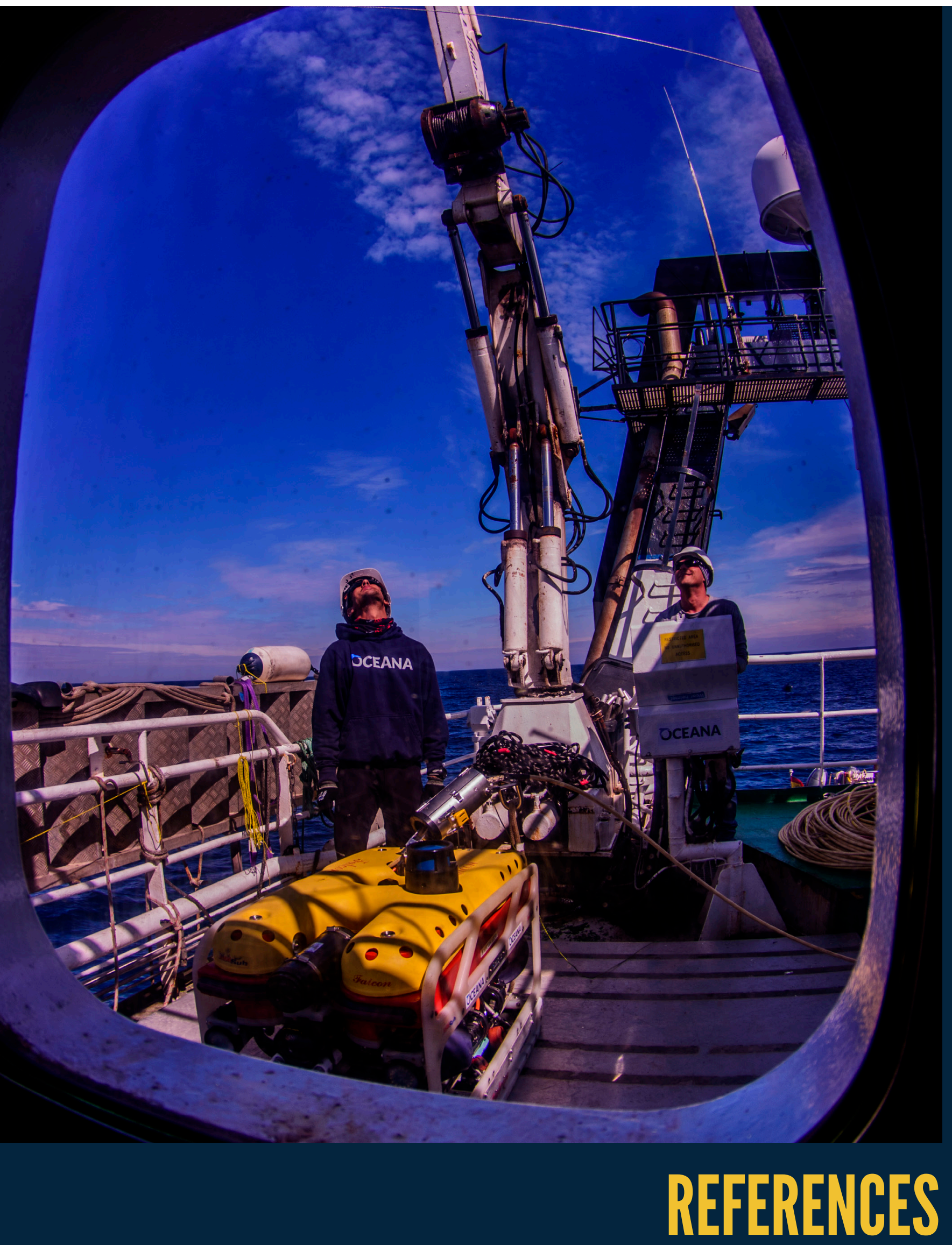


1 Sündermann, J., \& Pohlmann, T. 2011. A brief analysis of North Sea physics. Oceanologia 53: 663-689.

${ }^{2}$ Witbaard, R., Bos, O.G., \& Lindeboom, H.J. 2008. Basisinformatie over de Borkumer Stenen, Bruine Bank en Gasfonteinen, potentieel te beschermen gebieden op het NCP. Report No. C026/08. IMARES, Wageningen, the Netherlands.

${ }^{3}$ Ward, I. 2014. Depositional Context as the Foundation to Determining the Paleolithic and Mesolithic Archaeological Potential of Offshore Wind Farm Areas in the Southern North Sea. Conservation and Management of Archaeological Sites 16: 212-235.

${ }^{4}$ Lindeboom, H.J., van Kessel, J.G., \& Berkenbosch, L. 2005. Areas with special ecological values on the Dutch Continental Shelf. Report No. RIKZ/2005.008 and Alterra Report No. 1203. Alterra, Wageningen UR and Ministerie van Verkeer en Waterstaat. Rijkswaterstaat.

${ }^{5}$ Bos, O.G., \& van Bemmelen, R. 2012. Aanvullende beschermde gebieden Noordzee: Samenvatting onderzoek 2009-2012. Report No. C154/12. IMARES, Wageningen, the Netherlands.

${ }^{6}$ Leopold, M.F., \& van der Wal, J.T. 2015. Kwalificerende en niet-kwalificerende vogelsoorten in het gebied "Bruine Bank." Report No. C015/16. IMARES, Wageningen, the Netherlands.

${ }^{7}$ van Kooten, T., Deerenberg, C.M., Jak, R.G., van Hal, R., \& Machiels, M.A.M. 2015. An exploration of potential effects on fisheries and exploited stocks of a network of marine protected areas in the North Sea. Report No. C093/14. IMARES, Wageningen, the Netherlands.

${ }^{8}$ van de Meene, J.W.H., \& van Rijn, L.C. 2000. The shoreface-connected ridges along the central Dutch coast-part 1: field observations. Continental Shelf Research 20: 2295-2323.

${ }^{9}$ van Dijk, T.A.G.P., van Dalfsen, J.A., van Lancker, V., van Overmeeren, R.A., van Heteren, S., \& Doornenbal, P.J. 2012. Benthic habitat variations over tidal ridges, North Sea, the Netherlands. In: Harris, P.T., \& Baker, E.K. (Eds.) Seafloor Geomorphology as Benthic Habitat: GeoHAB Atlas of Seafloor Geomorphic Features and Benthic Habitats. pp. 241-249. Elsevier, Amsterdam, the Netherlands.

${ }^{10}$ Vanaverbeke, J., Gheskiere, T., Steyaert, M., \& Vincx, M. 2002. Nematode assemblages from subtidal sandbanks in the Southern Bight of the North Sea: effect of small sedimentological differences. Journal of Sea Research 48: 197-207.

${ }^{11}$ Alldredge, A.L., \& Hamner, W.M. 1980. Recurring aggregation of zooplankton by a tidal current. Estuarine and Coastal Marine Science 10: 31-37. 
12 Jones, L.A., Coyle, M.D., Evans, D., Gilliland, P.M., \& Murray, A.R. 2004. Southern North Sea Marine Natural Area Profile: A contribution to regional planning and management of the seas around England. English Nature, Peterborough, UK.

${ }^{13}$ Laban, C. 2006. Seabed mapping in the Dutch sector of the North Sea. Sea Technology 47: 47-51.

${ }^{14}$ Flemming, N.C., Harff, J., Burgess, A., Bailey, G.N., \& Moura, D. (Eds.) 2017. Submerged landscapes of the European continental shelf: Quaternary paleoenvironments (Vol. 1). Wiley-Blackwell, Chichester, UK.

${ }^{15}$ Holtmann, S.E., \& Groenewold, A. 1994. Distribution of the zoobenthos on the Dutch continental shelf: The Western Frisian Front, Brown Bank and Broad Fourteens (1992/1993). NIOZ Report No. 1994-1 and NIOO-CEMO Report No.1994-1. Netherlands Institute for Sea Research, Netherlands Institute of Ecology - Centre for Estuarine and Coastal Ecology, and North Sea Directorate, Ministry of Transport and Public Works.

${ }^{16}$ Kolfschoten, T.V., \& Laban, C. 1995. Pleistocene terrestrial mammal faunas from the North Sea area. Mededelingen Rijks Geologische Dienst 52: 135-151.

${ }^{17}$ Bynoe, R. 2014. The great fossil mine of the southern North Sea: exploring the potential of submerged Palaeolithic archaeology. Doctoral dissertation, University of Southampton, UK.

${ }^{18}$ Bos, O.G., Witbaard, R., Lavaleye, M., van Moorsel, G., Teal, L.R., van Hal, R., van der Hammen, T., ter Hofstede, R., van Bemmelen, R., Witte, R.H., Geelhoed, S., \& Dijkman, E.M. 2011. Biodiversity hotspots on the Dutch Continental Shelf: A Marine Strategy Framework Perspective. Report No. C071/11. IMARES, Wageningen, the Netherlands.

19 JNCC. 2017. Inshore and Offshore Special Area of Conservation: Southern North Sea. SAC Selection Assessment Document. Joint Nature Conservation Committee, Aberdeen, UK.

${ }^{20}$ Geelhoed, S.C.V., Scheidat, M., van Bemmelen, R.S.A, \& Aarts, G. 2013. Abundance of harbour porpoises (Phocoena phocoena) on the Dutch Continental Shelf, aerial surveys in July 2010-March 2011. Lutra 56: 45-57.

${ }^{21}$ Heinänen, S., \& Skov, H. 2015. The identification of discrete and persistent areas of relatively high harbour porpoise density in the wider UK marine area. JNCC Report No. 544. JNCC, Peterborough, UK.

${ }^{22}$ Hammond, P.S., Macleod, K., Berggren, P., Borchers, D.L., Burt, L., Cañadas, A., Desportes, G., Donovan, G., Gilles, A., Gillespie, D., Gordon, J., Hiby, L., Kuklik, I., Leaper, R., Lehnert, K., Leopold, M., Lovell, P., Øien, N., Paxton, C.G.M., Ridoux, V., Rogan, E., Samarra, F., Scheidat, M., Sequeira, M., Siebert, U., Skov, H., Swift, R., Tasker, M.L., Teilmann, J., Van Canneyt, O., \& Gordon, J. 2013. Cetacean abundance and distribution in European Atlantic shelf waters to inform conservation and management. Biological 
Conservation 164: 107-122.

${ }^{23}$ van Bemmelen, R.S.A., Leopold, M.F., \& Bos, O.G. 2012. Vogelwaarden van de Bruine Bank: Project Aanvullende Beschermde Gebieden. Report No. C138/12. IMARES, Wageningen, the Netherlands.

${ }^{24}$ Geelhoed, S.C.V., Bos, O.G., Burggraaf, D., Couperus, A.S., \& Lagerveld, S. 2014. Verklarende factoren voor de verspreiding van alken en zeekoeten op de Bruine Bank - Project Aanvullende Beschermde Gebieden Noordzee. Report No. C133/14. IMARES, Wageningen, the Netherlands.

${ }^{25}$ Worsøe Clausen, L., Horsten, M.B., \& Hoffmann, E. 2002. Gyde-og opvækstpladser for kommercielle fiskearter i Nordsøen, Skagerrak og Kattegat. Fiskeriundersøgelser, Danmarks. DFU-rapport No. 118-02. Charlottenlund, Danmarks Fiskeriundersøgelser.

${ }^{26}$ Ellis, J.R., Milligan, S.P., Readdy, L., Taylor, N., \& Brown, M.J. 2012. Spawning and nursery grounds of selected fish species in UK waters. Science Series Technical Report, 147. Cefas, Lowestoft, UK.

27 University of Bradford. 2018. Lost at sea! Expedition to find lost prehistoric settlement. 6 April 2018. Available from: https://www.bradford.ac.uk/ news/2018/brown-bank.php

${ }^{28}$ North Sea Foundation. 2017. DISCLOSE: Protecting vulnerable habitats in the North Sea. Available from: https://discloseweb.webhosting.rug.nl/

${ }^{29}$ Craeymeersch, J.A., Heip, C.H., \& Buijs, J. 1997. Atlas of North Sea benthic infauna: based on the 1986 North Sea Benthos Survey. ICES Cooperative Research Report, 218. International Council for the Exploration of the Sea, Copenhagen, Denmark.

${ }^{30}$ Rees, H. L., Eggleton, J. D., Rachor, E., \& Vanden Berghe, E. (Eds). 2007. Structure and dynamics of the North Sea benthos. ICES Cooperative Research Report, 288. International Council for the Exploration of the Sea, Copenhagen, Denmark.

${ }^{31}$ Hammond, P.S., Lacey, C., Gilles, A., Viquerat, S., Börjesson, P., Herr, H., Macleod, K., Ridoux. V., Santos, M.B., Scheidat, M., Teilmann, J., Vingada. J., \& Teilmann, J. 2017. Estimates of cetacean abundance in European Atlantic waters in summer 2016 from the SCANS-III aerial and shipboard surveys. Sea Mammal Research Unit, St Andrews, UK.

32 Scheidat, M., Verdaat, H., \& Aarts, G. 2012. Using aerial surveys to estimate density and distribution of harbour porpoises in Dutch waters. Journal of Sea Research 69: 1-7.

${ }^{33}$ Hammond, P.S., Berggren, P., Benke, H., Borchers, D.L., Collet, A., Heide-Jørgensen, M.P., Heimlich, S., Hiby, A.R., Leopold, M.F., \& Øien, N. 2002. Abundance of harbour porpoise and other cetaceans in the North Sea and adjacent waters. Journal of Applied Ecology 39: 361-376. 
${ }^{34}$ van Loon, W.M.G.M., \& Walvoort, D.J.J. 2018. Trend analysis results for benthic diversity of Dutch marine areas based on the OSPAR Margalef method. Ministry of Infrastructure and Environment, Rijkswaterstaat. Available from: http://publicaties.minienm.nl/documenten/trend-analysis-results-for-benthic-diversity-of-dutch-marine-areas-based-on-theospar-margalef-method

35 United Kingdom Hydrographic Office. 2015. Bathymetric Survey - 2014-0317 - DWR North Hinder to DWR Off Brown Ridge. Available from: https:// data.gov.uk/dataset/a75a4532-6b25-4702-a313-abe64460866d/ bathymetric-survey-2014-03-17-dwr-north-hinder-to-dwr-off-brown-ridge

${ }^{36}$ van Dijk, T., Doornenbal, P., Cupédo, R., \& Kulk, B. 2006. Survey report week 46, 2006. Survey site: Brown Bank. 13-17 November, 2006. TNO and RWS. Available from: www.emodnet-seabedhabitats.eu/pdf/06-06-12 TNO Brown Bank Arca Nov2006.pdf

${ }^{37}$ Maljers, D., Stafleu, J., Wiersma, A., Kiden, P., \& Frantsen, P. 2010. De ontwikkeling van een delfstoffeninformatiesysteem voor het NCP: resultaten van een pilotstudie. Report No. 1003-0138. Deltares, Delft, The Netherlands.

38 United Kingdom Hydrographic Office. 1995. Bathymetric Survey - 199503-14 - Brown Ridge Traffic Separation Scheme to North Hinder Traffic Separation Scheme. Available from: https://data.gov.uk/dataset/bbbb9d4e-af09-415e-a135-de2d02b7ecff/bathymetric-survey-1995-03-14brown-ridge-traffic-seperation-scheme-to-north-hinder-traffic-seperation-scheme

39 ICES. 2008. Working Group on Beam Trawl Surveys. Available from: http:// www.ices.dk/community/groups/Pages/WGBEAM.aspx

${ }^{40}$ Geelhoed, S.C.V., \& Leopold, M.F. 2016. Cruiserapport scheepstellingen van zeevogels op het Friese Front en op de Bruine Bank. Report No. C032/17. 36. IMARES, Wageningen, the Netherlands

${ }^{41}$ OSPAR Commission. 2010. Quality Status Report 2010, Region II - Greater North Sea. OSPAR Commission. London, UK. Available from: https:// qsr2010.ospar.org/en/ch12_02.html

${ }^{42}$ Thurstan, R.H., Brockington, S., \& Roberts, C.M. 2010. The effects of 118 years of industrial fishing on UK bottom trawl fisheries. Nature Communications 1: 15.

${ }^{43}$ Cardinale, M., Bartolino, V., Svedäng, H., Sundelöf, A., Poulsen, R.T., \& Casini, M. 2014. A centurial development of the North Sea fish megafauna as reflected by the historical Swedish longlining fisheries. Fish and Fisheries 16: 522-533.

${ }^{44}$ Lescrauwaet, A.-K., Debergh, H., Vincx, M., \& Mees, J. 2010. Fishing in the past: Historical data on sea fisheries landings in Belgium. Marine Policy 34: 1279-1289 
45 Jennings, S., \& Blanchard, J.L. 2004. Fish abundance with no fishing: predictions based on macroecological theory. Journal of Animal Ecology 73: 632-642.

${ }^{46}$ Prins, T.C., Slijkerman, D.M.E., de Mesel, I., Schipper, C.A., \& van den Heuvel-Greve, M.J. 2011. Initial Assessment Implementation of the Marine Strategy Framework Directive for the Dutch part of the North Sea. Background document 1 (of 3). Report No. C112/11. IMARES \& Deltares. Delft, the Netherlands.

${ }^{47}$ ICES. 2017. Greater North Sea Ecoregion - Fisheries overview. ICES Fisheries Overviews, ICES Advice 2017. DOI: 10.17895/ices.pub.3721

48 Sys, K., Poos, J.J., van Meensel, J., Polet, H., \& Buysse, J. 2016. Competitive interactions between two fishing fleets in the North Sea. ICES Journal of Marine Science 73: 1485-1493.

49 Doering, R., Kempf, A., Belschner, T., Berkenhagen, J., Bernreuther, M., Hentsch, S., Kraus, G., Raetz, H.-J., Rohlf, N., Simons, S., Stransky, C., \& Ulleweit, J. 2017. Research for PECH Committee: BREXIT consequences for the Common Fisheries Policy. Resources and Fisheries: A Case Study. European Parliament, Policy Department for Structural and Cohesion Policies, Brussels, Belgium.

${ }^{50}$ Royal HaskoningDHV. 2017. Norfolk Vanguard Offshore Wind Farm. Appendix 14.1. Commercial Fisheries Technical Report. Preliminary Environmental Information Report. Volume 3. Document PB4476-004-0141.

${ }^{51}$ ICES. 2017. OSPAR request on the production of spatial data layers of fishing intensity/pressure. In: Report of the ICES Advisory Committee, 2017. ICES Advice 2017, ICES Technical Service, sr.2017.17. 8 pp.

${ }^{52}$ van der Reijden, K.J., Verkempynck, R., Nijman, R.R., Uhlmann, S.S., van Helmond, A.T.M., \& Coers, A. 2014. Discard self-sampling of Dutch bottom-trawl and seine fisheries in 2013. Report No. 14.007. Stichting DLO, Centre for Fisheries Research (CVO).

${ }^{53}$ Scientific, Technical and Economic Committee for Fisheries (STECF). 2017. The 2017 Annual Economic Report on the EU Fishing Fleet (STECF-17-12). Publications Office of the European Union, Luxembourg. DOI:10.2760 /36154.

${ }^{54}$ ICES. 2018. Report of the Working Group on Electric Trawling (WGELECTRA). ICES Report WGELECTRA 2018. 17- 19 April 2018, IJmuiden, the Netherlands.

${ }^{55}$ Collie, J.S., Hall, S.J., Kaiser, M.J., \& Poiner, I.R. 2000. A quantitative analysis of fishing impacts on shelf-sea benthos. Journal of Animal Ecology 69: 785-798.

56 Jennings, S., Pinnegar, J.K., Polunin, N.V.C., \& Warr, K.J. 2001. Impacts of trawling disturbance on the trophic structure of benthic invertebrate communities. Marine Ecology Progress Series 213: 127-142. 
${ }^{57}$ Kaiser, M.J., Collie, J.S., Hall, S.J., Jennings, S., \& Poiner, I.R. 2002. Modification of marine habitats by trawling activities: prognosis and solutions. Fish and Fisheries 3: 114-136.

${ }^{58}$ Stokstad, E. 2018. Tensions flare over electric fishing in European waters. Science 359: 261.

${ }^{59}$ Eigaard, O.R., Bastardie, F., Breen, M., Dinesen, G.E., Hintzen, N.T., Laffargue, P., Mortensen, L.O., Nielsen, J.R., Nilsson, H.C., O'Neill, F.G., Polet, H., Reid, D.G., Sala, A., Sköld, M., Smith, C., Sørensen, T.K., Tully, O., Zengin, M., \& Rijnsdorp, A.D. 2015. Estimating seabed pressure from demersal trawls, seines, and dredges based on gear design and dimensions. ICES Journal of Marine Science 73 (Suppl. 1): i27-i43.

${ }^{60}$ Rijnsdorp, A.D., Bos, O.G., \& Slijkerman, D. 2015. Impact assessment of the flyshoot fishery in Natura 2000 and MSFD areas of the Dutch continental shelf. Report No. C162/15. IMARES, Wageningen, the Netherlands.

${ }^{61}$ Richardson, L. (Ed.). 2017. UK Sea Fisheries Statistics 2016. Marine Management Organisation, London, UK.

62 Jongbloed, R.H., Machiels, M.A.M., van der Wal, J.T., Hamon, K.G., \& van Oostenbrugge, J.A.E. 2015. Assessment of the impact of gillnet fishery on conservation objectives of seabirds in the Brown Ridge. Report No. C182/15. IMARES, Wageningen, the Netherlands.

${ }^{63}$ Wiebes, E. 2018. Offshore Wind Energy Roadmap 2030. Briefing to the President of the House of Representatives, from the Minister of Economic Affairs and Climate Policy. 27 March 2018. Available from: https://english. rvo.nl/sites/default/files/2018/03/Brief\%20routekaart\%20windenergie\%20op\%20zee\%202024-2030\%20-\%20EN.pdf

${ }^{64}$ Netherlands Ministry of Infrastructure and the Environment and Ministry of Economic Affairs. National Water Plan 2016-2021. Available from: https://www.government.nl/documents/policy-notes/2015/12/14/national-water-plan-2016-2021

${ }^{65}$ 4C Offshore. 2018. IJmuiden Ver - Unassigned Pre-2030 Capacity Offshore Wind Farm. Available from: http://www.4coffshore.com/windfarms/ ijmuiden-ver---unassigned-pre-2030-capacity-netherlands-nlOv.html

${ }^{66}$ Lensink, S.M. 2016. Kosten IJmuiden-Ver in relatie tot Hollandse Kust. Vrije Horizon. Project No. 5.4271. Available from: https://www.ecn.nl/publications/PdfFetch.aspx?nr=ECN-E--16-023

${ }^{67}$ United Kingdom Department of Energy and Climate Change. 2011. Renewable energy roadmap. Department of Energy \& Climate Change, London, UK.

${ }^{68}$ The Crown Estate. 2017. Offshore wind operational report January - December 2016. The Crown Estate, London, UK. 
${ }^{69}$ Royal HaskoningDHV. 2017. Norfolk Vanguard Offshore Wind Farm. Appendix 10.4: Habitats Regulations Assessment - Offshore Screening. Preliminary Environmental Information Report. Volume 3. Available from: https:// corporate.vattenfall.co.uk/globalassets/uk/projects/norfolk-vanguard/ consultation-peir-oct-2017/peir/volume-3-appendices/chapter-10-benthic-and-intertidal-ecology/appendix-10.4-norfolk-vanguard-offshore-hra-screening.pdf

70 North Sea Foundation. 2018. Windparken op de Noordzee: kansen en risico's voor de natuur. Stichting De Noordzee (North Sea Foundation). Utrecht, the Netherlands. Available from: https://www.noordzee.nl/ingrijpendeveranderingen-op-de-noordzee-door-de-groei-van-windparken-vragenom-meer-onderzoek/

${ }^{71}$ Hough, D. 2017. UK offshore oil and gas industry. Briefing paper. Number CBP 07268, 29 March 2017. House of Commons Library. Available from: https://researchbriefings.parliament.uk/ResearchBriefing/Summary/ CBP-7268\#fullreport

72 UK Department of Energy \& Climate Change. 2015. Offshore Oil \& Gas Licensing 28th Seaward Round Southern North Sea. Department of Energy \& Climate Change, London, UK. Available from: https://assets.publishing. service.gov.uk/government/uploads/system/uploads/attachment_data/ file/444920/28th_Round_Southern_North_Sea_Blocks_AA.pdf

73 Oil and Gas Authority. 2018. UK Oil and Gas Activity: Quadrant 53. Available from: https://itportal.ogauthority.co.uk/web_files/gis/quadmaps/Q_53

74 Oil and Gas Authority. 2018. UK Oil and Gas Activity: Quadrant 54. Available from: https://itportal.ogauthority.co.uk/web_files/gis/quadmaps/Q_54

75 Netherlands Ministry of Infrastructure and Environment \& Ministry of Economic Affairs, Agriculture and Innovation. 2012. Marine Strategy for the Dutch part of the North Sea 2012-2020, Part 1. Available from: www. noordzeeloket.nl/publish/pages/115832/marine_strategy_framework_ directive_marine_strategy_for_the_dutch_part_of_the_north_sea_20122020_pa.pdf

${ }^{76}$ Nilsson, H., van Overloop, J., Mehdi, R.A., \& Pålsson, J. 2018. Transnational Maritime Spatial Planning in the North Sea: Report on Work-package 4 of the North SEE Project. Available from: http://www.northsearegion.eu/ northsee

77 Lister, J., Poulsen, R. T., \& Ponte, S. 2015. Orchestrating transnational environmental governance in maritime shipping. Global Environmental Change 34: 185-195.

78 Weilgart, L.S. 2007. The impacts of anthropogenic ocean noise on cetaceans and implications for management. Canadian Journal of Zoology 85: 10911116. 
${ }^{79}$ Abdulla, A., \& Linden, O. (Eds.). 2008. Maritime traffic effects on biodiversity in the Mediterranean Sea: Review of impacts, priority areas and mitigation measures (Vol. 1). IUCN Centre for Mediterranean Cooperation. Malaga, Spain.

80 Wilson, B., Batty, R. S., Daunt, F., \& Carter, C. 2006. Collision risks between marine renewable energy devices and mammals, fish and diving birds. Report to the Scottish Executive. Scottish Association for Marine Science, Oban, United Kingdom.

${ }^{81}$ Leopold, M.F., Boonman, M., Collier, M.P., Davaasuren, N., Fijn, R.C., Gyimesi, A., de Jong, J., Jongbloed, R.H., Jonge Poerink, B., Kleyheeg-Hartman, J.C., Krijgsveld, K.L., Lagerveld, S., Lensink, R., Poot, M.J.M., van der Wal. J.T., \& Scholl, M. 2014. A first approach to deal with cumulative effects on birds and bats of offshore wind farms and other human activities in the Southern North Sea. Report No. C166/14. IMARES, Wageningen, the Netherlands.

82 UK Department for Transport. 2015. Maritime Growth Study: Keeping the UK competitive in a global market. Department for Transport, London, UK.

${ }^{83}$ Christiansen, S., \& Lutter, S. 2009. Towards good environmental status: a network of Marine Protected Areas for the North Sea. WWF Germany. Frankfurt, Germany.

${ }^{84}$ JNCC. 2018. Southern North Sea MPA. Available from: http://jncc.defra.gov. uk/page-7243

85 JNCC \& Natural England. 2016. Harbour Porpoise (Phocoena phocoena) possible Special Area of Conservation: Southern North Sea. Draft Conservation Objectives and Advice on Activities. Available from: http://jncc. defra.gov.uk/pdf/SouthernNorthSeaConservationObjectivesAndAdviceOnActivities.pdf

${ }^{86}$ EEC. 1992. Council Directive 92/43/EEC of 21 May 1992 on the conservation of natural habitats and of wild fauna and flora. Official Journal of the European Union L 206, 22.7.1992, p.7.

${ }^{87}$ The Offshore Marine Conservation (Natural Habitats, \&c.) Regulations 2007. Available from: http://www.legislation.gov.uk/uksi/2007/1842/contents

${ }^{88}$ Netherlands Ministry of Transport, Public Works and Water Management, Ministry of Housing, Regional Development and the Environment, and Ministry of Agriculture, Nature, and Food Quality. National Water Plan 2009-2015. Available from: http://publicaties.minienm.nl/documenten/ national-water-plan-2009-2015

89 Netherlands Ministry of Infrastructure and the Environment, \& Ministry of Economic Affairs. 2015. Marine Strategy for the Dutch part of the North Sea: 2012-2020. Part 3. MSFD programme of measures. Available from: https://www.noordzeeloket.nl/publish/pages/126271/marine_strategy_ for_the_dutch_part_of_the_north_sea_2012-2020_-_part_3_msfd_programme_of_measures.pdf 
90 Netherlands Ministry of Infrastructure and Water Management \& Ministry of Agriculture, Nature and Food Quality. 2018. Marine Strategy (Part 1). Update of current environmental status, good environmental status, environmental targets and indicators: 2018-2024. Main document (English translation). Available from: http://ec.europa.eu/environment/marine/public-consultation/pdf/marine_strategy_part_1_main_document_draft.pdf

${ }^{91}$ North Sea Foundation. 2018. Gebiedsbescherming op de Nederlandse Noordzee. De stand van zaken in relatie tot visserij. Stichting De Noordzee (North Sea Foundation). Utrecht, the Netherlands. Available from: https://www.noordzee.nl/project/userfiles//2018a_Stichting_De_Noordzee_Brochure_Beschermde_Gebieden.pdf

92 Vogelbescherming Nederland. 2018. Vogelbescherming: wijs Bruine Bank aan als beschermd gebied voor alken en zeekoeten. 12 July 2018. Available from: https://www.vogelbescherming.nl/actueel/bericht/vogelbescherming-wijsbruine-bank-aan-als-beschermd-gebied-voor-alken-en-zeekoeten

${ }^{93}$ Hugenholtz, E. 2008. The Dutch Case - A Network of Marine Protected Areas. WWF Netherlands. Zeist, Netherlands.

${ }^{94}$ Gratwicke, B., \& Speight, M.R. 2005. The relationship between fish species richness, abundance and habitat complexity in a range of shallow tropical marine habitats. Journal of Fish Biology 66: 650-667.

${ }^{95}$ Hendrick, V.J., \& Foster-Smith, R.L. 2006. Sabellaria spinulosa reef: a scoring system for evaluating 'reefiness' in the context of the Habitats Directive. Journal of the Marine Biological Association of the United Kingdom 86: 665-677.

${ }^{96}$ Kiessling, W. 2005. Long-term relationships between ecological stability and biodiversity in Phanerozoic reefs. Nature 433: 410.

${ }^{97}$ Gubbay, S. 2007. Defining and managing Sabellaria spinulosa reefs: Report of an inter-agency workshop 1-2 May, 2007. JNCC Report No. 405. Joint Nature Conservation Committee, Peterborough, UK.

${ }^{98}$ JNCC \& Natural England. 2016. Review of the MCZ Features of Conservation Importance. Available from: http://jncc.defra.gov.uk/pdf/20160512_ MCZReviewFOCI_v7.0.pdf

99 OSPAR Commission. 2008. Descriptions of Habitats on the OSPAR List of Threatened and/or Declining Species and Habitats. OSPAR Commission, London, UK. Available from: https://www.ospar.org/documents? $d=32797$

${ }^{100}$ van der Reijden, K., Koop, L., O'Flynn, S., Garcia, S., Bos, O., van Sluis, C., Maaholm, D.J., Herman, P.M.J., Simons, D.G., Olff, H., Ysebaert, T., Snellen, M., Govers, L.L., Rijnsdorp, A.D., \& Aguilar, R. 2019. Discovery of Sabellaria spinulosa reefs in an intensively fished area on the Dutch Continental Shelf, North Sea. Journal of Sea Research 144: 85-94. 
101 Pearce, B. 2014. The ecology of Sabellaria spinulosa reefs. Doctoral dissertation. Plymouth University, Plymouth, UK.

102 Griffin, R., B. Pearce, \& Handy, R.D. 2012. Dietary preference and feeding selectivity of common dragonet Callionymus lyra in UK. Journal of Fish Biology 81: 1019-1031.

${ }^{103}$ Sims, D.W., Wearmouth, V.J., Southall, E.J., Hill, J.M., Moore, P., Rawlinson, K., Hutchinson, N., Budd, G.C., Righton, D., Metcalfe, J.D., Nash, J.P., \& Morritt, D. 2006. Hunt warm, rest cool: bioenergetic strategy underlying diel vertical migration of a benthic shark. Journal of Animal Ecology 75: 176-190.

104 Jenkins, C., Eggleton, J., Albrecht, J., Barry, J., Duncan, G., Golding, N., \& O'Connor, J., 2015. North Norfolk Sandbank and Saturn Reef cSAC/SCI management investigation report. JNCC/Cefas Partnership Report, No. 7.

105 Names, locations, and other details of the two wrecks were obtained from The Wrecksite online database. Available at: https://www.wrecksite.eu/

${ }^{106}$ Rappé, G. 2008. De Zee van Toen: Een historisch-ecologisch verkenning van de zuidelijke Noordzee (1930-1980), uit de mond van Vlaamse vissers. Provincie West-Vlaanderen, Bruges, Belgium.

107 OSPAR Commission. 2013. Background document on Sabellaria spinulosa reefs. OSPAR Commission, London, UK. Available from: https://www. ospar.org/documents? $v=7342$

108 Gravina, M.F., Cardone, F., Bonifazi, A., Bertrandino, M.S., Chimienti, G., Longo, C., Nonnis Marzano, C., Moretti, M., Lisco, S., Moretti, V., Corriero, G., \& Giangrande, A. 2018. Sabellaria spinulosa (Polychaeta, Annelida) reefs in the Mediterranean Sea: Habitat mapping, dynamics and associated fauna for conservation management. Estuarine, Coastal and Shelf Science 200: 248-257.

${ }^{109}$ Chapman, N. (Ed.) 2011. Sabellaria spinulosa Reefs. In: Maddock, A. (Ed.) UK Biodiversity Action Plan: Priority Habitat Descriptions. Biodiversity Reporting and Information Group. Available from: http://jncc.defra.gov.uk/ PDF/UKBAP_PriorityHabitatDesc-Rev2011.pdf

${ }^{110}$ European Environment Agency. 2012. Sabellaria spinulosa on stable circalittoral mixed sediment. EUNIS Habitat Classification 2012. Available from: http://eunis.eea.europa.eu/habitats/1693

${ }^{111}$ European Commission. 2013. Interpretation Manual of European Union Habitats. EUR 28. DG Environment, European Commission. Available from: http://ec.europa.eu/environment/nature/legislation/habitatsdirective/ docs/Int_Manual_EU28.pdf

112 European Commission. 2008. Directive 2008/56/EC of the European Parliament and of the Council of 17 June 2008 establishing a framework for community action in the field of marine environmental policy (Marine 
Strategy Framework Directive). Official Journal of the European Union L 164, 25.6.2008, p.19.

${ }^{113}$ Netherlands Ministry of Infrastructure and Water Management, \& Ministry of Agriculture, Nature and Food Quality. 2018. Marine Strategy Part 1. Update of current environmental status, good environmental status, environmental targets and indicators. Available from: http://ec.europa.eu/ environment/marine/publicconsultation/pdf/marine_strategy_part_1_ main_document_draft.pdf

${ }^{114}$ OSPAR Commission. 2010. Quality Status Report. Sabellaria spinulosa reefs. OSPAR Commission, London, UK. Available from: https://qsr2010.ospar. org/media/assessments/Species/p0010_supplements/CH10_04_Sabellaria_spinulosa.pdf

115 Knaapen, M.A.F. 2009. Sandbank occurrence on the Dutch continental shelf in the North Sea. Geo-Marine Letters 29: 17-24.

116 JNCC. 2018. Annex I sandbanks in offshore waters. Joint Nature Conservation Committee, Peterborough, UK. Available from: http://jncc.defra.gov. uk/page-1452

117 Noordzeeloket. 2016. Protected sites. Netherlands Ministry of Infrastructure and the Environment. Rotterdam, the Netherlands. Available from: https:// www.noordzeeloket.nl/en/policy/noordzee-natura-2000/gebieden/

118 JNCC. 2009. Selection criteria and guiding principles for selection of Special Areas of Conservation (SACs) for marine Annex I habitats and Annex II species in the UK. Joint Nature Conservation Committee. Available from: http://jncc.defra.gov.uk/PDF/MarineSAC_SelectionCriteria_030609.pdf

119 ETC/BD. 2014. National Summary for Article 17 - Netherlands. National Summary 2007-2012. European Topic Centre on Biological Diversity. Available from: https://circabc.europa.eu/sd/a/01efde37-fbd7-404d81dc-611fb2ae7dae/NL_20140528.pdf

${ }^{120}$ ETC/BD. 2014. National Summary for Article 17 - United Kingdom. National Summary 2007-2012. European Topic Centre on Biological Diversity. Available from: https://circabc.europa.eu/sd/a/e731be00-187d-48ed9a37-897b9f201756/UK_20140528.pdf

121 Janssen, J.A.M., Weeda, E.J., Schippers, P., Bijlsma, R.J., Schaminée, J.H.J., Arts, G.H.P., Deerenberg, C.M., Bos, O.G. \& Jak, R.G. 2014. Habitat types at Natura 2000 sites. Assessment of area, representativity and degree of conservation for the Standard Data Forms (SDFs). Wageningen, Statutory Research Tasks Unit for Nature \& the Environment (WOT Natuur \& Milieu). WOT Technical Report 8.

122 OSPAR Commission. 2008. Case reports for the OSPAR list of threatened and/or declining species and habitats. OSPAR Commission, London, UK. 
Available from: https://qsr2010.ospar.org/media/assessments/p00358_ case_reports_species_and_habitats_2008.pdf

${ }^{123}$ OSPAR Commission. 2009. Background document for Ostrea edulis and Ostrea edulis beds. OSPAR Commission, London, UK. Available from: https:// www.ospar.org/documents? $=7183$

${ }^{124}$ Beck, M.W., Brumbaugh, R.D., Airoldi, L., Carranza, A., Coen, L.D., Crawford, C., Defeo, O., Edgar, G.J., Hancock, B., Kay, M.C., Lenihan, H.S., Luckenbach, M.W., Toropova, C.L., Zhang, G., \& Guo, X. 2011. Oyster reefs at risk and recommendations for conservation, restoration, and management. BioScience 61: 107-116.

125 OSPAR Commission. 2013. OSPAR Recommendation 2013/4 on furthering the protection and conservation of Ostrea edulis in Region II of the OSPAR maritime area and Ostrea edulis beds in Regions II, III and IV of the OSPAR maritime area. Available from: https://www.ospar.org/documents?d=32968

126 ICES. 2018. Cod (Gadus morhua) in Subarea 4, Division 7.d, and Subdivision 20 (North Sea, eastern English Channel, Skagerrak). ICES Advice on fishing opportunities, catch, and effort. Greater North Sea Ecoregion. Copenhagen, Denmark. DOI: 10.17895/ices.pub.4436. Available from: http:// www.ices.dk/sites/pub/Publication\%20Reports/Advice/2018/2018/ cod.27.47d20.pdf

127 JNCC. 1994. The UK Biodiversity Action Plan (UK BAP): 1992-2012. Available from: http://jncc.defra.gov.uk/ukbap

128 Freyhof, J. 2014. Pleuronectes platessa. The IUCN Red List of Threatened Species 2014: e.T135690A50018800. Available from: http://dx.doi. org/10.2305/IUCN.UK.2014-1.RLTS.T135690A50018800.en.

129 ICES. 2018. Plaice (Pleuronectes platessa) in Subarea 4 (North Sea) and Subdivision 20 (Skagerrak). ICES Advice on fishing opportunities, catch, and effort. Greater North Sea Ecoregion. Copenhagen, Denmark. DOI: 10.17895/ices.pub.4445 Available from: http://ices.dk/sites/pub/Publication\%20Reports/Advice/2018/2018/ple.27.420.pdf

130 Monroe, T., Keskin, Ç., Costa, M. \& Rijnsdorp, A.D. 2015. Solea solea. The IUCN Red List of Threatened Species 2015: e.T198739A87698320.

131 ICES. 2018. Sole (Solea solea) in Subarea 4 (North Sea). ICES Advice on fishing opportunities, catch, and effort. Greater North Sea Ecoregion. Copenhagen, Denmark. DOI: 10.17895/ices.pub.4458. Available from: http://www.ices. dk/sites/pub/Publication\%20Reports/Advice/2018/2018/sol.27.4.pdf

132 OSPAR Commission. 2010. Background Document for Common skate Dipturus batis. OSPAR Commission, London, UK. Available from: https:// www.ospar.org/documents?d=7227 
133 OSPAR Commission. 2010. Background Document for Thornback ray Raja clavata. OSPAR Commission, London, UK. Available from: https://www. ospar.org/documents?d=7225

134 ICES. 2017. Thornback ray (Raja clavata) in Subarea 4 and in divisions 3.a and 7.d (North Sea, Skagerrak, Kattegat, and eastern English Channel). ICES Advice on fishing opportunities, catch, and effort. Greater North Sea Ecoregion. Available from: http://ices.dk/sites/pub/Publication\%20Reports/Advice/2017/2017/rjc.27.3a47d.pdf

135 Tien, N.S.H., Heessen, H., Kranenberg, J., \& Trapman, B. 2016. Achtergronddocument Rode Lijst Vissen 2011. Zoutwatervissen. Report No. C021/16. IMARES, Wageningen, the Netherlands. Available from: http:// edepot.wur.nl/378196

136 ICES. 2016. Greater North Sea ECOREGION - Ecosystem overview. ICES Ecosystem Overviews. ICES Advice 2016, Book 6. Copenhagen, Denmark. Available from: http://www.ices.dk/sites/pub/Publication\%20 Reports/Advice/2016/2016/Greater_North_Sea_Ecoregion-Ecosystem_ overview.pdf

${ }^{137}$ Reid, J.B., Evans, P.G.H., \& Northridge, S.P. 2003. Atlas of cetacean distribution in North-West European waters. Joint Nature Conservation Committee, Peterborough, UK.

${ }^{138}$ Sea Watch Foundation. 2012.Threats to UK cetaceans. Available from: http:// seawatchfoundation.org.uk/wp-content/uploads/2012/07/Threats-toUK-cetaceans.pdf

139 Netherlands Ministry of Agriculture, Nature and Food Quality. 2004. Rode lijsten: soort van Rode Lijst Vissen. Available from: http://minez.nederlandsesoorten.nl/content/rode-lijsten-soort-van-rode-lijst-vissen

140 EUROSTAT. 2018. Commercial species from 2008-2017 in FAO 27.4c fishing area. Available from: http://ec.europa.eu/eurostat/web/fisheries/data/ database

${ }^{141}$ O'Neill, F.G., \& Ivanović, A. 2015. The physical impact of towed demersal fishing gears on soft sediments. ICES Journal of Marine Science 73 (Suppl. 1): i5-i14.

${ }^{142}$ Eigaard, O.R., Bastardie, F., Hintzen, N., Buhl-Mortensen, L., Buhl-Mortensen, P., Catarino, R., Dinesen, G.E., Fock, H., Geitner, K., Gerritsen, H., Gonzalez, M.M., Jonsson, P., Kavadas, S., Laffargue, P., Lundy, M., Mirelis, G.G., Nielsen, R., Papadopoulou, N., Posen, P., Pulcinella, J., Russo, T., Sala, A., Silva, C., Smith, C., Vanelslander, B., Zengin, M., \& Rijnsdorp, A.D. 2015. Benthic impact of fisheries in European waters: the distribution and intensity of bottom trawling. BENTHIS - Deliverable 2.3. Available from: https://www.benthis.eu/upload_mm/c/2/9/ d143d86e-e9d0-411f-9a18-389751352abf_D2.3\%20Manuscript\%20benthic\%20impact.\%20Subm\%20date\%2001-10-2015\%20PU.pdf 
143 Tillin, H.M., Hiddink, J.G., Jennings, S., \& Kaiser, M.J. 2006. Chronic bottom trawling alters the functional composition of benthic invertebrate communities on a sea-basin scale. Marine Ecology Progress Series 318: 31-45.

144 OSPAR Commission. 2013. Recommendation 2013/2 on furthering the protection and conservation of Sabellaria spinulosa reefs in Regions II and III of the OSPAR maritime area. OSPAR 13/4/1, Annex 5. Available from: https://www.ospar.org/documents?d=32964

145 Gibb, N., Tillin, H.M., Pearce, B., \& Tyler-Walters, H. 2014. Assessing the sensitivity of Sabellaria spinulosa to pressures associated with marine activities. Report No. 504. Joint Nature Conservation Committee, Peterborough, UK. Available from: http://jncc.defra.gov.uk/pdf/JNCC_Report_504_web.pdf 


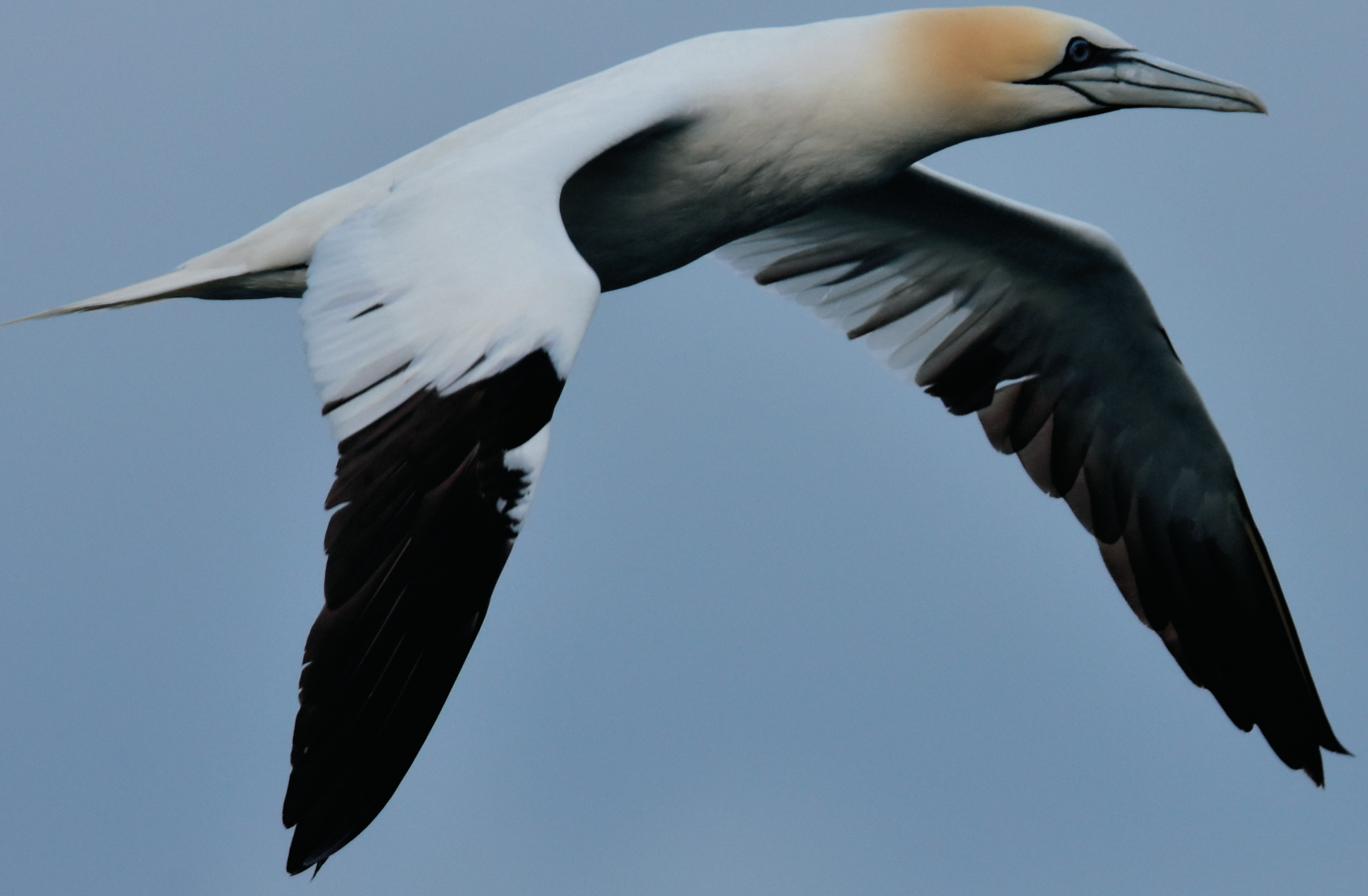

ANNEX: RECORDED TAXA 
Table A. Taxa documented in the Brown Bank study area during Oceana North Sea research expeditions in 2016 and 2017. Taxa are listed according to whether they occurred in the waters of the Netherlands (NL) or the United Kingdom (UK).

\begin{tabular}{|c|c|c|}
\hline Species & NL & UK \\
\hline ALGAE & & \\
\hline Chlorophyceae indet. & $x$ & \\
\hline Desmarestia aculeata & $x$ & \\
\hline Fucus serratus & $x$ & \\
\hline Fucus sp. & $x$ & \\
\hline Fucus spiralis & $x$ & $x$ \\
\hline Fucus vesiculosus & $x$ & $x$ \\
\hline $\begin{array}{l}\text { Gracilariopsis longis- } \\
\text { sima }\end{array}$ & & $x$ \\
\hline Halidrys siliquosa & $x$ & \\
\hline Himanthalia elongata & $x$ & \\
\hline Phaeophyceae indet. & $x$ & \\
\hline Rhodophyta indet. & $x$ & \\
\hline Ulva cf. intestinalis & $x$ & \\
\hline Ulva intestinalis & $x$ & \\
\hline Ulva sp. & $x$ & \\
\hline \multicolumn{3}{|l|}{ ANNELIDA } \\
\hline Annelida indet. & $x$ & \\
\hline Lanice conchilega & $x$ & \\
\hline cf. Owenia fusiformis & $x$ & $x$ \\
\hline Owenia fusiformis & $x$ & $x$ \\
\hline Oweniidae indet. & $x$ & \\
\hline Pectinariidae indet. & $x$ & \\
\hline Polychaeta indet. & $x$ & \\
\hline Sabellaria spinulosa & $x$ & $x$ \\
\hline $\begin{array}{c}\text { Spirobranchus tri- } \\
\text { queter }\end{array}$ & & $x$ \\
\hline Spirorbidae indet. & $x$ & \\
\hline \multicolumn{3}{|l|}{ ARTHROPODA } \\
\hline Amphipoda indet. & $x$ & \\
\hline $\begin{array}{c}\text { Atelecyclus undecim- } \\
\text { dentatus }\end{array}$ & $x$ & \\
\hline Balanomorpha indet. & $x$ & \\
\hline Balanus crenatus & & $x$ \\
\hline Balanus sp. & $x$ & \\
\hline Bathyporeia sp. & $x$ & \\
\hline Brachyura indet. & $x$ & \\
\hline Cancer pagurus & $x$ & \\
\hline Caprella linearis & $x$ & \\
\hline
\end{tabular}

\begin{tabular}{|c|c|c|}
\hline Species & $\mathbf{N L}$ & UK \\
\hline Carcinus maenas & $x$ & \\
\hline Copepoda indet. & $x$ & \\
\hline \multicolumn{3}{|l|}{ Decapoda indet. } \\
\hline Diogenes pugilator & $x$ & $x$ \\
\hline Eualus cranchii & $x$ & \\
\hline \multicolumn{3}{|l|}{ Inachus sp. } \\
\hline $\begin{array}{l}\text { Ischyrocerus mega- } \\
\text { lops }\end{array}$ & $x$ & \\
\hline Isopoda indet. & & $x$ \\
\hline Liocarcinus depurator & $x$ & \\
\hline Liocarcinus holsatus & $x$ & $x$ \\
\hline $\begin{array}{l}\text { Liocarcinus marmo- } \\
\text { reus }\end{array}$ & $x$ & \\
\hline Liocarcinus pusillus & $x$ & \\
\hline Liocarcinus sp. & $x$ & $x$ \\
\hline Macropodia rostrata & $x$ & \\
\hline Necora puber & $x$ & $x$ \\
\hline Pagurus bernhardus & $x$ & $x$ \\
\hline Pagurus prideaux & $x$ & \\
\hline Pandalina brevirostris & $x$ & \\
\hline Pisidia longicornis & $x$ & \\
\hline Porcellana platycheles & $x$ & \\
\hline \multicolumn{3}{|l|}{ BRYOZOA } \\
\hline Bryozoa indet. & & $x$ \\
\hline Crisularia plumosa & $x$ & \\
\hline \multicolumn{3}{|l|}{ CHORDATA } \\
\hline Agonus cataphractus & $x$ & \\
\hline Ammodytes sp. & & $x$ \\
\hline Ammodytes tobianus & $x$ & $x$ \\
\hline Arnoglossus laterna & $x$ & $x$ \\
\hline Arnoglossus thori & & $x$ \\
\hline Ascidiacea indet. & $x$ & \\
\hline $\begin{array}{c}\text { Balaenoptera acuto- } \\
\text { rostrata }\end{array}$ & $x$ & \\
\hline Buglossidium luteum & $x$ & \\
\hline Callionymus lyra & $x$ & $x$ \\
\hline Callyonimus sp. & $x$ & $x$ \\
\hline $\begin{array}{c}\text { Callionymus reticu- } \\
\text { latus }\end{array}$ & $x$ & \\
\hline Clupeidae indet. & $x$ & \\
\hline
\end{tabular}




\begin{tabular}{|c|c|c|}
\hline Species & NL & UK \\
\hline $\begin{array}{l}\text { Delphinidae/Phoco- } \\
\text { enidae indet. }\end{array}$ & $x$ & \\
\hline Echiichthys vipera & $x$ & $x$ \\
\hline Entelurus aequoreus & $x$ & \\
\hline Eutrigla gurnardus & & $x$ \\
\hline Gadus morhua & $x$ & \\
\hline Gobiidae indet. & $x$ & \\
\hline $\begin{array}{c}\text { Hippoglossoides pla- } \\
\text { tessoides }\end{array}$ & $x$ & \\
\hline Limanda limanda & $x$ & $x$ \\
\hline $\begin{array}{c}\text { Micromesistius pou- } \\
\text { tassou }\end{array}$ & $x$ & \\
\hline Mullus surmuletus & $x$ & \\
\hline Pholis gunnellus & $x$ & \\
\hline Platichthys flesus & $x$ & $x$ \\
\hline Pleuronectes platessa & $x$ & \\
\hline $\begin{array}{l}\text { Pleuronectidae in- } \\
\text { det. }\end{array}$ & $x$ & $x$ \\
\hline $\begin{array}{l}\text { Pleuronectiformes } \\
\text { indet. }\end{array}$ & $x$ & $x$ \\
\hline Pollachius pollachius & $x$ & \\
\hline Pollachius sp. & & \\
\hline $\begin{array}{l}\text { Pomatoschistus } \\
\text { pictus }\end{array}$ & $\mathrm{x}$ & \\
\hline Pomatoschistus sp. & $x$ & \\
\hline Raja clavata & $x$ & \\
\hline Scyliorhinus canicula & $x$ & \\
\hline Solea solea & $x$ & \\
\hline Soleidae indet. & $x$ & $x$ \\
\hline Sprattus sprattus & $x$ & \\
\hline cf. Sprattus sprattus & $x$ & \\
\hline Syngnathus acus & $x$ & \\
\hline Trachinidae indet. & $x$ & $x$ \\
\hline Trachinus draco & $x$ & \\
\hline Trachurus trachurus & $x$ & \\
\hline Triglidae indet. & & $x$ \\
\hline Trisopterus esmarkii & $x$ & \\
\hline Trisopterus luscus & $x$ & \\
\hline Trisopterus minutus & $x$ & \\
\hline \multicolumn{3}{|l|}{ CNIDARIA } \\
\hline Actiniaria indet. & $x$ & \\
\hline $\begin{array}{c}\text { Actinothoe sphyro- } \\
\text { deta }\end{array}$ & $x$ & \\
\hline Alcyonium digitatum & $\mathrm{x}$ & \\
\hline Aurelia aurita & $x$ & \\
\hline Bolocera tuediae & $x$ & \\
\hline
\end{tabular}

\begin{tabular}{|c|c|c|}
\hline Species & NL & UK \\
\hline Cereus pedunculatus & $x$ & \\
\hline Corymorpha nutans & $x$ & \\
\hline Cyanea capillata & $x$ & \\
\hline Cyanea lamarckii & $x$ & \\
\hline Diadumene cincta & $x$ & \\
\hline Ectopleura larynx & $x$ & $x$ \\
\hline Hydractinia echinata & $x$ & $x$ \\
\hline Hydrallmania falcata & $x$ & \\
\hline Hydroidolina indet. & $x$ & \\
\hline Hydrozoa indet. & $x$ & \\
\hline Metridium senile & $x$ & \\
\hline Nemertesia antennina & $x$ & \\
\hline Nemertesia ramosa & $x$ & \\
\hline Obelia sp. & $x$ & $x$ \\
\hline Rhizostoma octopus & $x$ & \\
\hline Sagartia elegans & $x$ & \\
\hline Sagartia sp. & $x$ & \\
\hline Sagartiogeton sp. & $x$ & \\
\hline $\begin{array}{c}\text { Sagartiogeton un- } \\
\text { datus }\end{array}$ & $x$ & \\
\hline Sertularia argentea & $x$ & \\
\hline Tubularia indivisa & $x$ & \\
\hline \multicolumn{3}{|l|}{ ECHINODERMATA } \\
\hline Amphiura filiformis & & $x$ \\
\hline Asterias rubens & $x$ & $x$ \\
\hline $\begin{array}{l}\text { Astropecten irregu- } \\
\text { laris }\end{array}$ & $x$ & \\
\hline Brissopsis atlantica & & $x$ \\
\hline Brissopsis sp. & & $x$ \\
\hline Brissus unicolor & $x$ & \\
\hline $\begin{array}{l}\text { Echinocardium cor- } \\
\text { datum }\end{array}$ & $x$ & $x$ \\
\hline $\begin{array}{l}\text { Echinocyamus pu- } \\
\text { sillus }\end{array}$ & $x$ & $x$ \\
\hline Echinoidea indet. & $x$ & \\
\hline Ophiothrix fragilis & $x$ & \\
\hline Ophiura albida & $x$ & $x$ \\
\hline Ophiura ophiura & $x$ & $x$ \\
\hline Ophiura sp. & $x$ & \\
\hline Ophiuroidea indet. & $x$ & \\
\hline Spatangoida indet. & $x$ & \\
\hline Spatangus purpureus & & $x$ \\
\hline
\end{tabular}




\begin{tabular}{|c|c|c|}
\hline Species & NL & UK \\
\hline MOLLUSCA & & \\
\hline Abra alba & & $x$ \\
\hline Abra logicallus & $x$ & \\
\hline Abra prismatica & $x$ & $x$ \\
\hline Alvania lactea & $x$ & \\
\hline Anomia ephippium & $x$ & \\
\hline Anomiidae indet. & & $x$ \\
\hline $\begin{array}{c}\text { Asbjornsenia pyg- } \\
\text { maea }\end{array}$ & $x$ & $x$ \\
\hline Astarte crenata & & $x$ \\
\hline Astarte sulcata & $x$ & \\
\hline Bathyarca philippiana & $x$ & \\
\hline Bivalvia indet. & $x$ & \\
\hline Cardiidae indet. & $x$ & $x$ \\
\hline Carronella pellucida & $x$ & \\
\hline Cerastoderma edule & $x$ & $x$ \\
\hline $\begin{array}{l}\text { Cerastoderma } \\
\text { glaucum }\end{array}$ & $\mathrm{x}$ & \\
\hline Chamelea striatula & & $x$ \\
\hline Donax sp. & $x$ & \\
\hline Donax variegatus & $x$ & \\
\hline Donax vittatus & $x$ & $x$ \\
\hline Dosinia exoleta & $x$ & \\
\hline Ensis leei & $x$ & \\
\hline Ensis sp. & $x$ & \\
\hline Euspira catena & $x$ & $x$ \\
\hline Euspira cf. catena & & $x$ \\
\hline cf. Euspira catena & & $x$ \\
\hline Euspira fusca & $x$ & \\
\hline Euspira nitida & & $x$ \\
\hline Euspira sp. & $x$ & $x$ \\
\hline Fabulina fabula & $x$ & $x$ \\
\hline Gastropoda indet. & $x$ & \\
\hline Gouldia minima & & $x$ \\
\hline Limecola balthica & $x$ & $x$ \\
\hline Littorina littorea & $x$ & \\
\hline Mactra sp. & & $x$ \\
\hline Mactra stultorum & $x$ & \\
\hline Mangelia sp. & & $x$ \\
\hline Mimachlamys varia & & $x$ \\
\hline Modiolus modiolus & & $x$ \\
\hline Moerella donacina & $x$ & \\
\hline Mysia undata & $x$ & \\
\hline Nucula hanleyi & & $x$ \\
\hline
\end{tabular}

\begin{tabular}{|c|c|c|}
\hline Species & $\mathbf{N L}$ & UK \\
\hline Oenopota tenuicostata & $x$ & \\
\hline Ostrea edulis & & $x$ \\
\hline Pectinidae indet. & $x$ & $x$ \\
\hline Peringia ulvae & $x$ & \\
\hline Rissoidea indet. & $x$ & \\
\hline Sessilia indet. & $x$ & \\
\hline Spisula elliptica & $x$ & $x$ \\
\hline Spisula sp. & $x$ & \\
\hline Spisula subtruncata & & $x$ \\
\hline Striarca lactea & & $x$ \\
\hline Tellina sp. & $x$ & \\
\hline Thracia sp. & $x$ & \\
\hline Tornus subcarinatus & $x$ & \\
\hline Tritia reticulata & & $x$ \\
\hline Trivia arctica & & $x$ \\
\hline \multicolumn{3}{|l|}{ PORIFERA } \\
\hline Antho sp. & $x$ & \\
\hline $\begin{array}{l}\text { cf. Halichondria } \\
\text { panicea }\end{array}$ & $x$ & \\
\hline Halichondria panicea & $x$ & \\
\hline $\begin{array}{l}\text { cf. Myxilla (Myxilla) } \\
\text { incrustans }\end{array}$ & $x$ & \\
\hline Porifera indet. & $x$ & \\
\hline $\begin{array}{l}\text { cf. Protosuberites } \\
\text { incrustans }\end{array}$ & $x$ & \\
\hline
\end{tabular}




\section{PROTECTING THE NORTH SEA: BROWN BANK}

\section{European Headquarters - Spain}

Gran Vía 59

28013 Madrid, Spain

Phone: + 34911440880

E-mail: europe@oceana.org

\section{Belgium}

Rue Montoyer 39

1000 Brussels, Belgium

Phone: + 32 (0)2 5132242

E-mail: brussels@oceana.org

\section{Denmark}

Nyhavn 16

1051 Copenhagen, Denmark

Phone: + 4533151160

E-mail: copenhagen@oceana.org

\section{United Kingdom}

Audley House

13 Palace St.

Victoria, SWIE 5HX, London, UK

E-mail: oceanauk@oceana.org 